UNIVERSIDADE DE SÃO PAULO

FACULDADE DE ECONOMIA, ADMINISTRAÇÃO E CONTABILIDADE DEPARTAMENTO DE ADMINISTRAÇÃO PROGRAMA DE PÓS-GRADUAÇÃO EM ADMINISTRAÇÃO

REDUÇÃO DE CUSTOS ATRAVÉS DO MANUFACTURING EXECUTION SYSTEM (MES) E SUA INTEGRAÇÃO COM O ENTERPRISE RESOURCE PLANNING (ERP)

Rafael Yuji Matsubara

Orientadora: Profa. Dra. Adriana Marotti de Mello

SÃO PAULO 
Prof. Dr. Marco Antonio Zago

Reitor da Universidade de São Paulo

Prof. Dr. Reinaldo Guerreiro

Diretor da Faculdade de Economia, Administração e Contabilidade

Prof. Dr. Roberto Sbragia

Chefe do Departamento de Administração

Prof. Dr. Lindolfo Galvão de Albuquerque

Coordenador do Programa de Pós-Graduação em Administração 


\section{REDUÇÃO DE CUSTOS ATRAVÉS DO MANUFACTURING EXECUTION SYSTEM (MES) E SUA INTEGRAÇÃO COM O ENTERPRISE RESOURCE PLANNING (ERP)}

Dissertação apresentada ao Departamento de Administração da Faculdade de Economia, Administração e Contabilidade da Universidade de São Paulo como requisito para obtenção do título de Mestre em Ciências

Orientadora: Profa. Dra. Adriana Marotti de Mello

\section{Versão Corrigida}

(versão original disponível na Faculdade de Economia, Administração e Contabilidade)

\section{SÃO PAULO}


FICHA CATALOGRÁFICA

Elaborada pela Seção de Processamento Técnico do SBD/FEA/USP

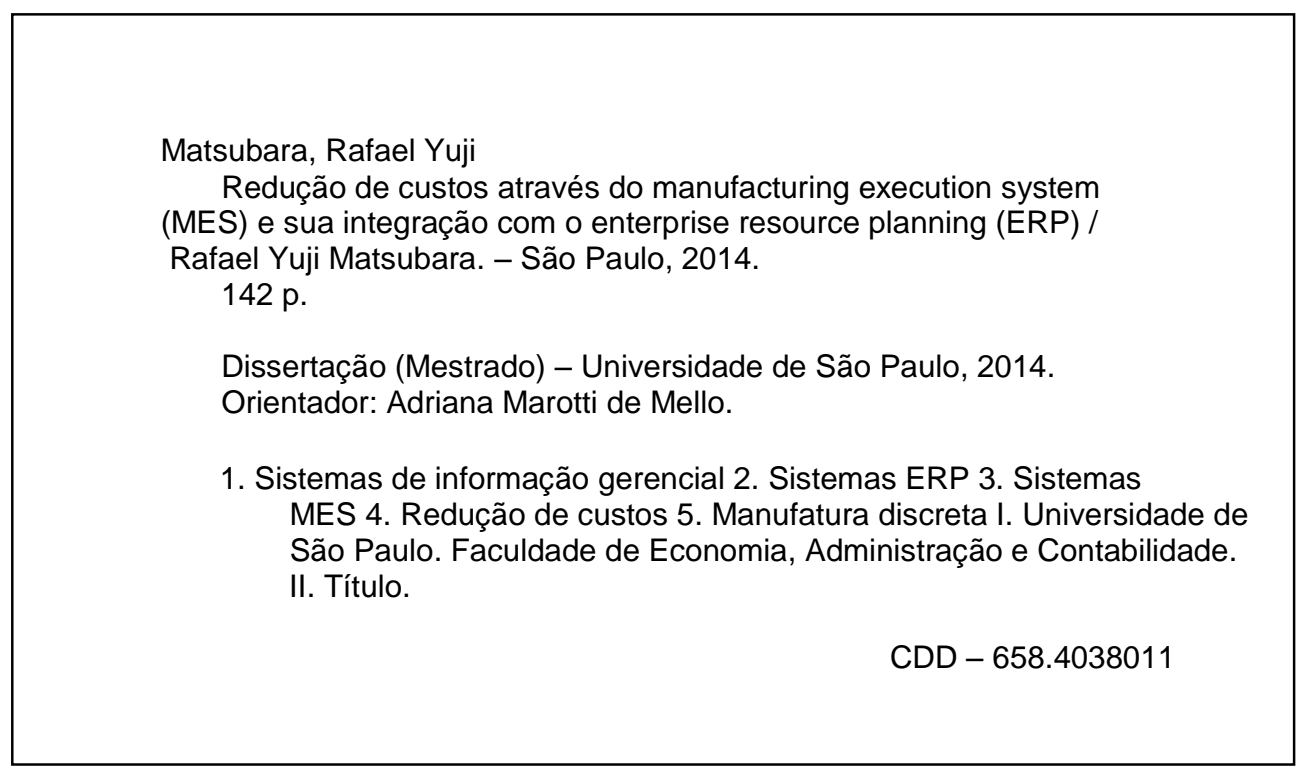


Dedico este trabalho aos meus pais, Jorge e Massako, e à minha irmã, Patrícia, que em todos os momentos da minha vida me apoiaram e incentivaram incondicionalmente. 
Em primeiro lugar à Deus por todas as oportunidades recebidas e graças alcançadas.

Aos meus queridos pais, Jorge e Massako, por ensinarem o significado da conquista e o valor dos estudos. Graças aos seus inestimáveis esforços e ensinamentos foi possível a realização deste projeto.

À minha irmã, Patrícia, e ao seu marido, Maurício, pessoas que considero muito, pelo incentivo e apoio concedidos ao longo de todo o curso.

À minha querida parceira, Natalia, pela atenção e inúmeras contribuições através de sua participação neste projeto e no decorrer do curso, compartilhando momentos importantes.

À minha orientadora, professora Adriana, pela excepcional contribuição, pelos preciosos ensinamentos e pelos cuidados atribuídos durante a elaboração deste projeto.

Ao estimado professor Marilson, por toda a atenção e fundamental contribuição concedidas durante o período de concepção do estudo e pela oportunidade de ingresso no programa.

Aos gestores e participantes das entrevistas, sem os quais não seria possível o desenvolvimento da dissertação.

Ao departamento e secretaria do Programa de Pós-Graduação de Administração da FEAUSP e aos estimados colegas da Universidade. 


\section{RESUMO}

A dissertação aborda o estudo sobre as principais características observadas sob a perspectiva da redução de custos em indústrias de manufatura discreta, em especial considerando uma possível integração dos Sistemas Enterprise Resource Planning (ERP) com os chamados Manufacturing Execution Systems (MES). Este estudo procura elucidar acerca das iniciativas orientadas à redução de custos, especialmente aquelas aplicadas em manufaturas do tipo discreta. Por meio do método de estudo múltiplo de casos foram coletados dados a respeito da implementação do MES e seus impactos sobre a redução de custos em três organizações, para que fossem debatidas as visões de diversos gestores, verificando se as proposições levantadas ao longo do projeto são confirmadas. Por fim, os resultados observados foram analisados e discutidos, e as conclusões apontam que o uso do sistema MES pode contribuir ou possui potencial para reduzir os custos e também para aumentar o controle da gestão. No entanto, foi possível observar também que a implantação de sistemas deve ser acompanhada de mudanças de processos e de cultura, que propiciem de fato a redução de custos nas empresas. Foram propostas novas possibilidades para que seja possível a continuidade de outros estudos neste sentido, de forma que as organizações possam explorar novas possibilidades, aperfeiçoando os sistemas ou desenvolvendo mudanças em seus processos.

Palavras-chave: Sistemas ERP, Sistemas MES, Redução de Custos, Manufatura Discreta. 


\begin{abstract}
The dissertation describes the study on major features achieved from the perspective of cost decrease management within discrete manufacturing industries, especially considering a possible integration between Enterprise Resource Planning (ERP) systems with so-called Manufacturing Execution Systems (MES). This study seeks to enlighten a few initiatives on the subject concerned to cost reduction management belonged to the company, especially those applied among manufacturers whose type is settled as discrete. By using the multiple case study method, several data regarding MES implementation and also its impacts on cost decrease were gathered within three enterprises, and therefore used for debating some standpoints from several managers and verifying whether the assumptions made throughout the article are confirmed. Finally, the results obtained along this study were analyzed and discussed, and such findings lead to idea that MES system use can concur or has the potential to decrease costs and enhance the management control as well. However, it was also possible to behold that systems implementation should be followed by a culture and processes changes as well, that surely provide cost cutting among companies. It was proposed some other improvement possibilities in order to make possible the development of new efforts in this regard, in a way that enterprises are able to explore new paths, enhancing the systems or even developing changes in their processes.
\end{abstract}

Keywords: ERP Systems, MES Systems, Costs Reduction Management, Discrete Manufacturing. 


\section{SUMÁRIO}

LISTA DE ABREVIATURAS E SIGLAS .................................................................... 2

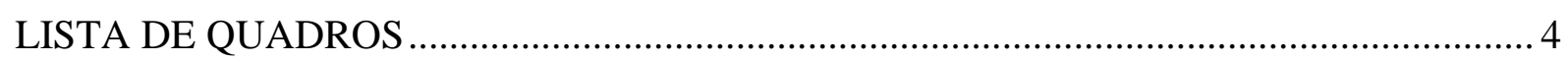

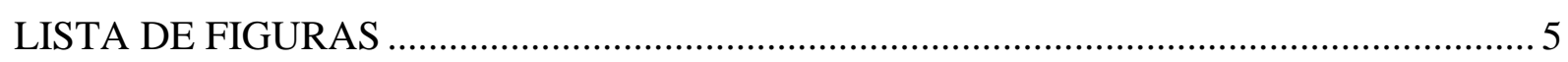

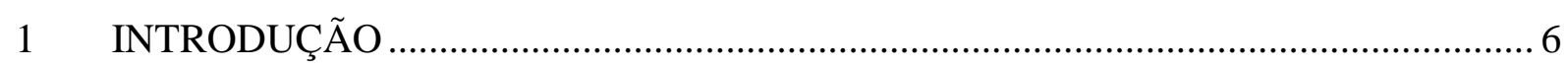

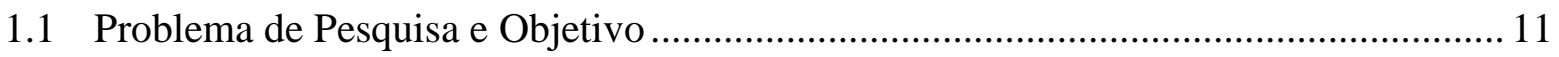

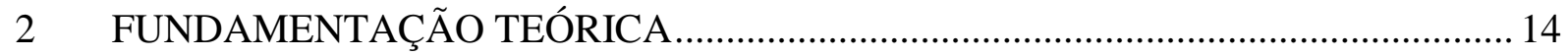

2.1 Evolução da tecnologia de informação na gestão da operação ...................................... 15

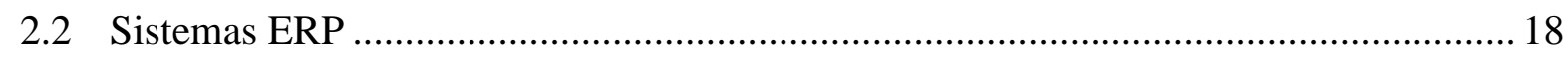

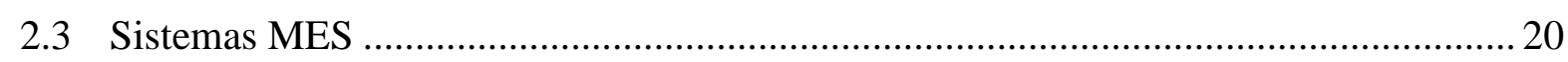

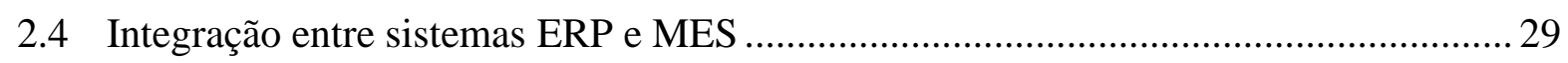

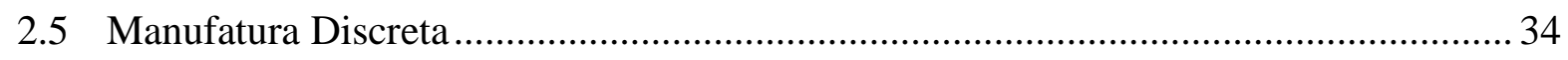

2.6 Impacto das integrações de sistemas ERP e MES para a operação .............................. 38

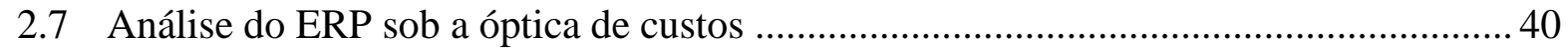

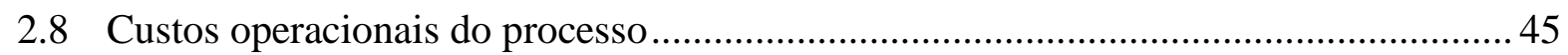

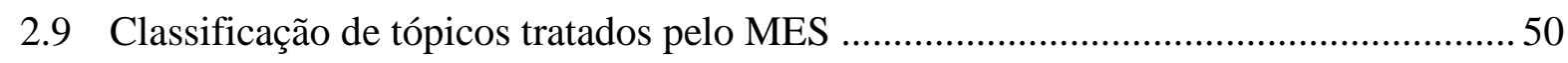

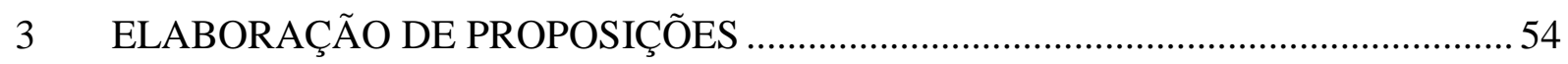

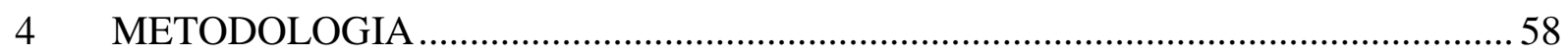

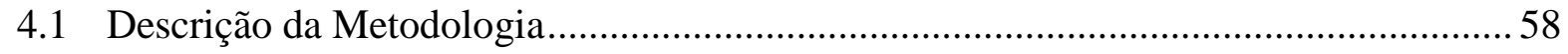

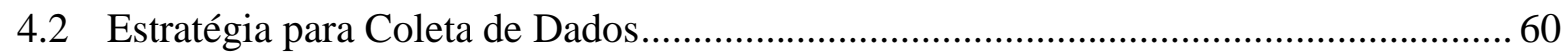

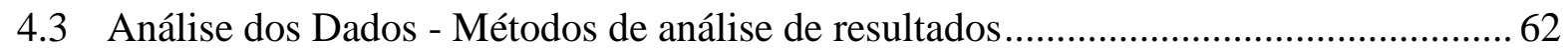

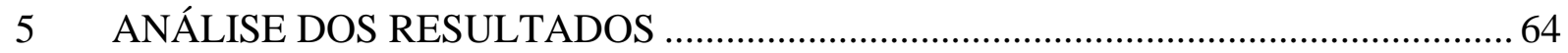

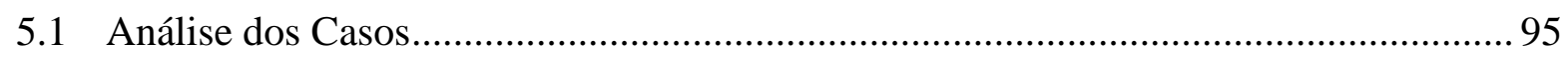

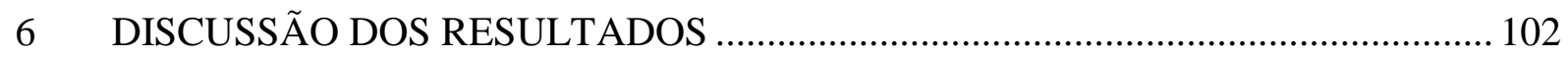

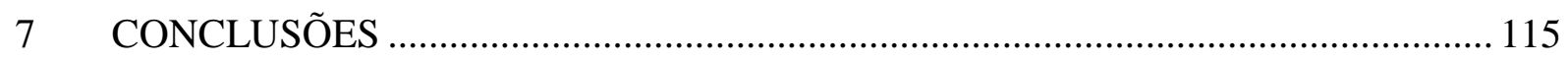

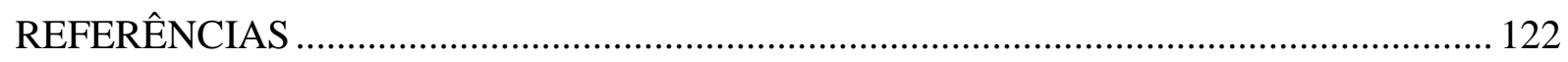

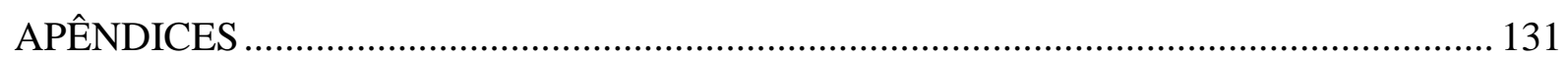

APÊNDICE 1 - CARTA DE APRESENTAÇÃO DA PESQUISA .................................... 132

APÊNDICE 2 - MODELO DE QUESTIONÁRIO SEMI-ESTRUTURADO .................... 132

APÊNDICE 3 - CRUZAMENTO DE RESULTADOS COM TABELA RESUMO ......... 137 


\section{LISTA DE ABREVIATURAS E SIGLAS}

ABC: Activity Based Costing

ABM: Activity Based Management

AIS: Automatic Information Systems

APICS: American Production and Inventory Control Society

BOM: Bill of Material

CAD: Computer Aided Design

CAM: Computer Aided Manufacturing

CIM: Computer Integrated Manufacturing

CLP: Controladores Lógico Programáveis

CNC: Computer Numerical Control

CNI: Confederação Nacional da Indústria

CRM: Customer Relationship Management

DCS: Distributed Control System

DLSP: Discrete Lot Sizing and Scheduling Problem

DRP: Distribution Requirements Planning

EDI: Electronic Data Interchange

ERP: Enterprise Resource Planning

FMS: Flexible Manufacturing Systems

GLSP-ST: General Lot Sizing Problem - Setup Times

ISA: International Society of Automation

MES: Manufacturing Execution System

MESA: Manufacturing Enterprise Solutions Association

MRP: Manufacturing Resource Planning

MTBF: Mean Time Between Failures

MTO: Make to Order

MTRF: Mean Time to Repair Failures

MTTR: Mean Time do Repair

MTS: Make to Stock

NEMA: National Electrical Manufactures Association

OEE: Overall Equipment Effectiveness

OPT: Optimized Production Technology

PCP: Planejamento e Controle da Produção

PFP: Planejamento Fino da Produção

RFID: Radio-Frequency Identification

ROI: Return On Investment

SCA: Scheduling Agent

SCADA: Supervisory Control and Data Acquisition

SDCD: Sistemas Digitais de Controle Distribuído

SFC: Shop Floor Control

SPC: Statistical Process Control

SQC: Statistic Quality Control

STA: Strategy Agent

SOP: Sales and Operations

TI: Tecnologia da Informação

TMS: Transportation Management System

TPC: Tambor-Pulmão-Corda

TQM: Total Quality Management 
VMI: Vendor Management Information VSM: Value Stream Mapping

WIP: Work In Process

WMS: Warehouse Management System 


\section{LISTA DE QUADROS}

Quadro 1 - Principais atributos oferecidos pelo MES …....................................................... 26

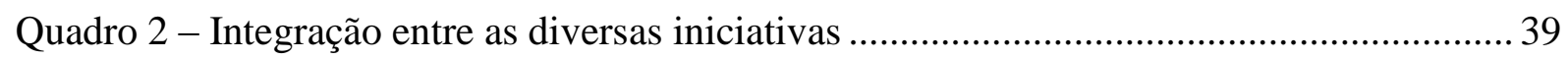

Quadro 3 - Quadro comparativo dos tipos de produção ....................................................... 49

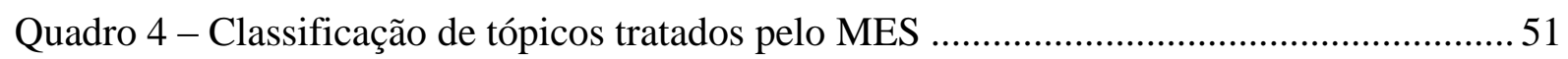

Quadro 5 - Resumo geral da implementação do MES ........................................................ 94

Quadro 6 - Principais atributos detectados no uso do MES ................................................... 95

Quadro 7 - Principais obstáculos detectados no uso do MES .............................................. 97

Quadro 8 - Principais problemas detectados no uso do MES............................................... 98

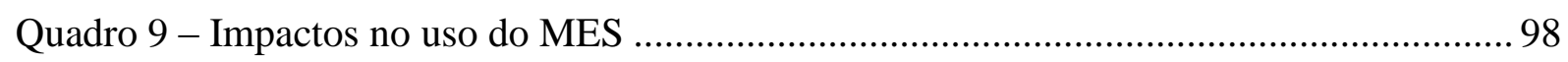

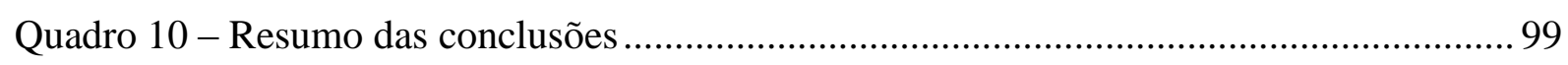

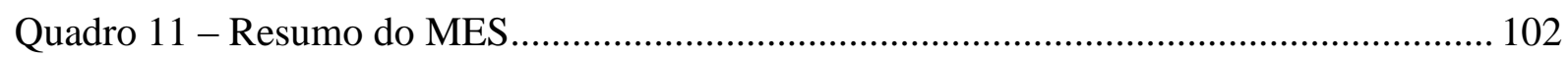

Quadro 12 - Agrupamento de dados por proposição ............................................................ 103

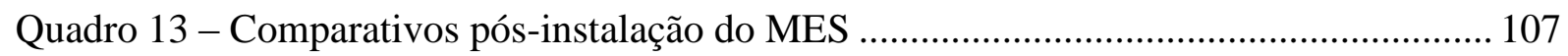

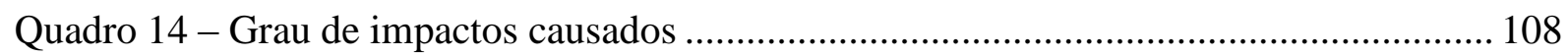




\section{LISTA DE FIGURAS}

Figura 1 - Desenvolvendo uma estratégia de operações. 8

Figura 2 - Evolução da tecnologia e das técnicas auxiliares do planejamento e controle da produção 15

Figura 3 - Integração entre as diversas iniciativas tecnológicas........................................... 18

Figura 4 - MES autônomo para integração empresarial ...................................................... 23

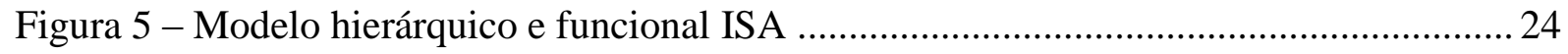

Figura 6 - Modelo de implementação do MES ......................................................................... 28

Figura 7 - Diagrama de fluxo da fase de controle na integração entre MES e a metodologia Seis Sigma. 30

Figura 8 - Modelo de inferência funcional para manufatura integrada na indústria automotiva 31

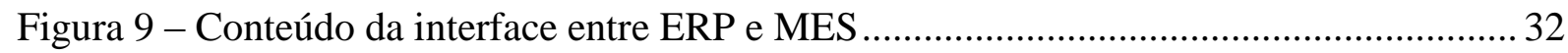

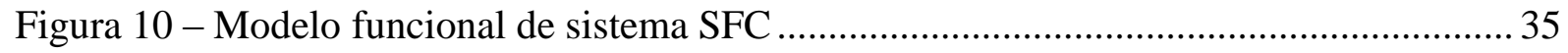

Figura 11 - Funcionalidades do sistema MES para diferentes tipos de manufatura................. 38

Figura 12 - Framework do sistema de gerenciamento de custos baseados no ERP e MES .... 46

Figura 13 - Hierarquia de custos de produção .................................................................... 50

Figura 14 - Variáveis do processo de fabricação ................................................................... 62

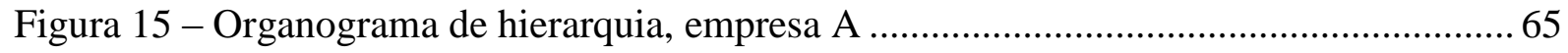

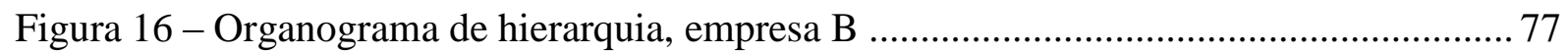

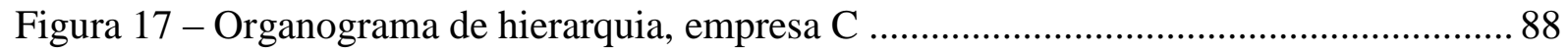

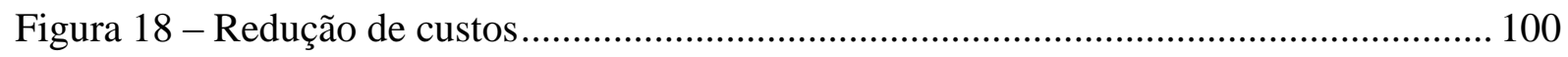

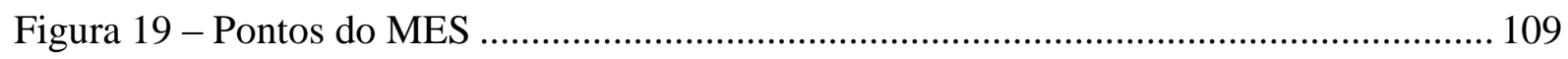

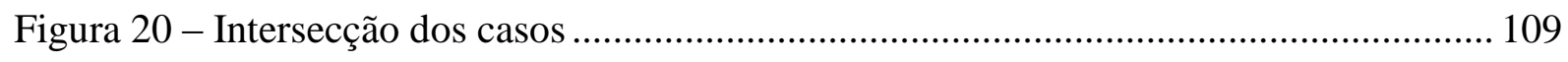

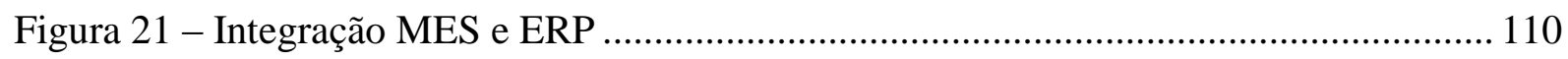

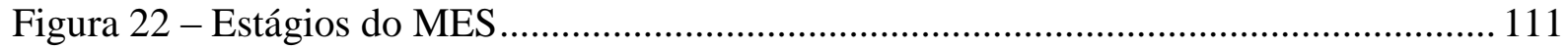

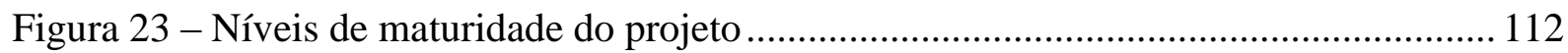

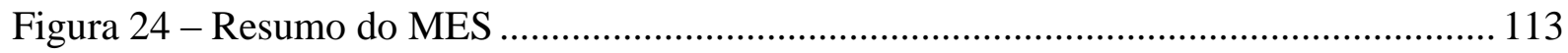




\section{INTRODUÇÃO}

O aumento da competitividade entre as indústrias que apresentam estratégias orientadas a diferenciação por preços determina uma busca constante pela redução de custos, através da implementação de sistemas e ferramentas capazes de prover soluções que viabilizem um melhor controle sobre as operações da produção, as quais devem refletir a estratégia de negócio adotada em uma corporação (KAPLAN e NORTON, 2009).

Conforme estudado por Hayes et al. (2008), a função produção deve ser orientada segundo uma estratégia composta por um conjunto de metas, políticas e restrições que otimizem e desenvolvam os elementos necessários para a condução da organização, planejamento e execução das atividades de produção.

Para Laurindo (2008), a TI, Tecnologia da Informação, pode se tornar um elemento chave para que a empresa possa se adaptar e se transformar, continuamente, acompanhando as mudanças geradas pela competição criando ou preservando as competências essenciais, minimizando fraquezas, fornecendo proteção contra ameaças do meio ambiente, bem como tirando proveito das oportunidades que possam surgir.

Em particular, convém averiguar as contribuições oriundas dos estudos da Tecnologia da Informação, em especial pela função de Produção em manufaturas discretas, dentre as diferentes áreas existentes em uma indústria e como estas iniciativas podem garantir a correta gestão e implementação do Planejamento Estratégico.

A motivação principal deste estudo é investigar como as ferramentas da Tecnologia da Informação, em especial o MES, Manufacturing Execution System e o ERP, Enterprise Resource Planning, podem contribuir para a redução de custos particularmente em organizações de manufatura discreta.

Este tipo de manufatura pode ser caracterizado como altamente complexo, no contexto do planejamento da produção, considerando a alta variabilidade de tipos de máquinas, operações, roteiros de produção e que normalmente apresentam inúmeras alternativas de processamento, constituídas de equipamentos diferentes, com prazos e quantidades definidos (JUNQUEIRA, 2003; MCKAY e BUZACOTT, 2000).

Os autores Banerjee et al. (2013) citam que a customização do sistema MES para a redução de custos, inclusive em várias empresas de pequeno e médio porte tem despontado como uma área de pesquisa significante. 
Ainda para estes autores, a área de manufatura por muitos anos esteve desconexa em relação às demais áreas da empresa justamente pelas barreiras encontradas na captura de dados reais e confiáveis o suficiente.

Caso haja qualquer ocorrência, tais fatos podem impactar não apenas o cotidiano das operações de uma planta, mas também outros elementos envolvidos na cadeia, gerando atraso para as transportadoras e também para a entrega dos produtos na rede varejista ou no cliente final.

Ao longo da história, diversas tecnologias foram desenvolvidas no sentido de aprimorar o processo produtivo de indústrias e aumentar o índice da eficiência global. Conforme verificado por Mesquita (2008), as primeiras foram denominadas MRP/MRP II, Material Resource Planning, cujos focos eram direcionados para o controle e cálculo de necessidade de materiais para uma grande variedade de componentes, além do planejamento da capacidade e gestão dos demais recursos de equipamentos e mão-de-obra.

Logo em seguida, foram aprimoradas e deram espaço aos chamados sistemas ERP, Enterprise Resource Planning, para os quais foi atribuída a função de organizar os dados da empresa e compartilhar informações de diferentes áreas, incluindo a de Produção, de forma integrada e em tempo real. Novas tecnologias têm sido estudadas e originadas em diversas áreas.

De acordo com Slack et al. (2002), um dos papéis da produção é implementar, apoiar e impulsionar a estratégia empresarial. Em adição, Gaither e Frazier (1999) afirmam que fazer uso da tecnologia avançada significa aplicar as mais recentes descobertas científicas ou da engenharia ao projeto de processos de produção.

A Figura 1 destaca a posição ocupada pela Tecnologia da Produção no contexto da Estratégia de Operações, enquanto fator essencial para o desenvolvimento de Competências Essenciais dentro da Estratégia de Negócios. 


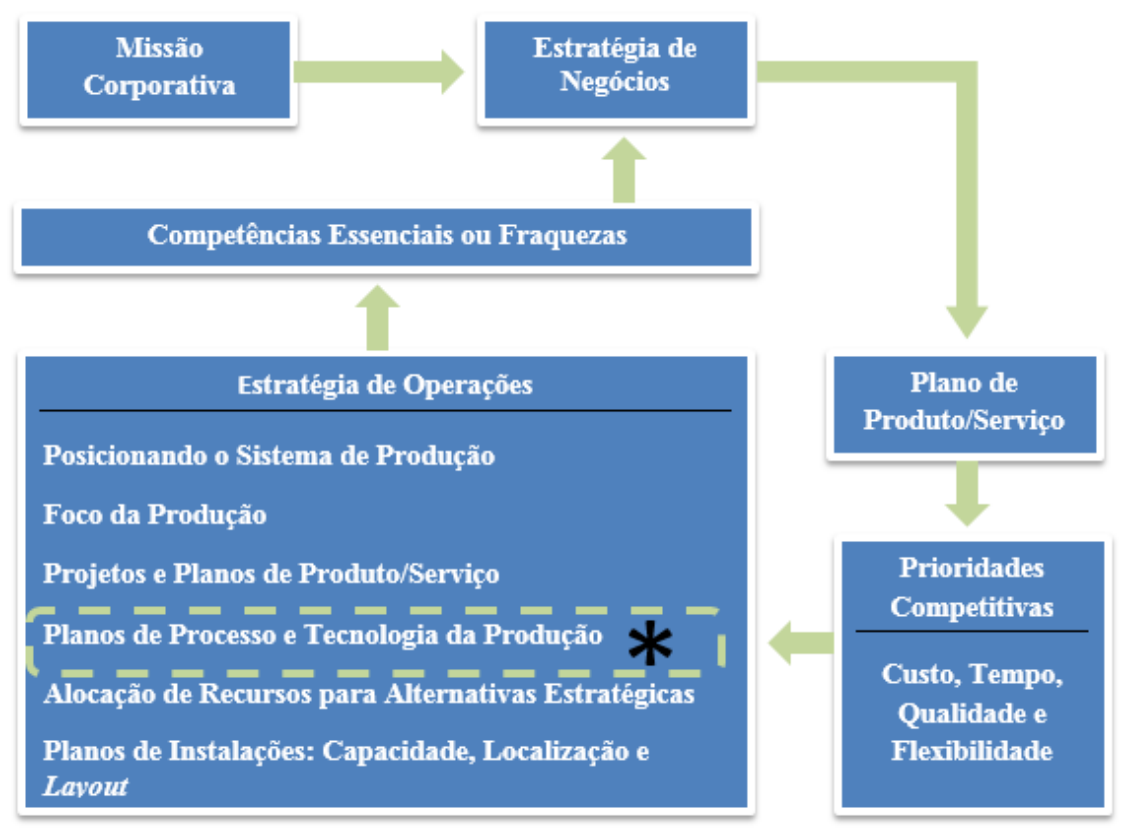

Figura 1 - Desenvolvendo uma estratégia de operações

FONTE: Adaptado de GAITHER; FRAZIER (1999).

Dentre as diversas tecnologias existentes no mercado serão abordadas especificamente neste estudo, o sistema ERP e os sistemas de dados da produção ou MES, Manufacturing Execution Systems, sob um ponto de vista de integração e redução de custos.

Este trabalho tem por objetivo a abordagem de eventuais melhorias obtidas no controle de custos, através da integração do ERP e o MES ou um possível uso isolado do MES, visando à redução de custos e considerando as circunstâncias das organizações, áreas de atuação, além dos obstáculos encontrados.

A escolha das tecnologias é justificada pelo fato de que os sistemas ERP têm sido amplamente utilizados em diversas empresas, porém estão orientados muito fortemente a uma visão macro, por meio de dados brutos para controles de rotina e obrigações fiscais da empresa.

Os sistemas MES são responsáveis pela coleta de dados de chão-de-fábrica em tempo real, através de dispositivos eletrônicos interligados aos sistemas de informação para armazenamento de dados. As principais informações transportadas do MES para o ERP seriam a respeito de jobs concluídos, consumo de estoque, atendimento às normas e requisitos, e performance de operação real (GIACON e MESQUITA, 2011; DEUEL, 1994).

Pela compreensão desta realidade, pode-se inferir que o primeiro é responsável pelo processamento e formatação atualizados dos dados, enquanto o segundo fornece um fluxo consistente de informações para o aumento da agilidade (DEUEL, 1994). 
Por outro lado, os softwares MES poderiam complementar a visão fornecida pelos sistemas ERP e dos controles de produção, no sentido de prover dados mais acurados e consistentes, atuando na liberação das ordens e no controle de suas informações ao mesmo tempo em que elimina o loop no controle do processo de produção. (DEUEL, 1994; WANG et al., 2012).

Em relação ao planejamento da produção, o MES executa as ordens geradas pelos sistemas MRP. Por outro lado, em relação ao fator processo, o MES providencia ao MRP informações acuradas e precisas, feedback atualizado em relação à utilização de recursos e resultados dos processos produtivos (GIACON e MESQUITA, 2011; DEUEL, 1994).

Em adição, o MES possibilita a ação imediata para corrigir problemas detectados no chão-de-fábrica e as condições fora de regularidade são identificadas antes que sejam incorridos custos, economizando tempo e capital (DEUEL, 1994; WANG et al., 2012).

Com o software MES, o gap de tempo para uma resposta imediata do operador pode ser reduzido, pois há um controle atualizado de rastreamento de processos e materiais de forma correlacionada (COTTYN et al., 2011; WANG et al., 2012).

Com isso, através de customização e integração entre as arquiteturas de ERP e MES, é possível apontar informações gerenciais adequadas para tomadas de decisão em uma empresa de manufatura, tais como os dados de Ordens de Produção em processamento e sujeitos às incertezas da produção. Para tal, os operadores devem contar com informações correlacionadas, que podem ser obtidas através da observação de inúmeras ocorrências no decorrer dos anos. (GIACON e MESQUITA, 2011; YIN e XIE, 2011).

Pautada na ideia de autores, deve existir uma correlação entre o controle de processos e as informações de materiais na medida em que ocorrem imprevistos no chão-de-fábrica, além disso, para cada processo existem componentes específicos demandados para a interface de sistemas com um ERP. Por meio do gerenciamento destes componentes, a instituição possuirá condições para realizar a integração em nível adequado dos sistemas ERP e MES (YIN e XIE, 2011; DEUEL, 1994).

Em seus estudos diversos autores comentam que o MES pode ser utilizado para prestar um suporte do controle de manufatura mais adequado e que promove autonomia no controle das atividades de logística também. Ademais, a integração do MES corrobora também para um alinhamento da visão financeira dos processos em paralelo ao acompanhamento dinâmico do chão-de-fábrica (BUNSER et al., 2011; REITER et al., 2009). 
Complementam diversos autores que o MES deve ser flexível o suficiente para acompanhar as constantes mudanças decorrentes de iniciativas de melhorias contínuas aplicadas nas organizações.

Assim, como o ERP, aponta-se uma relevância pela capacidade dos sistemas em gerar informações para o planejamento e execução dos modelos Lean Manufacturing e ainda interagir com os complementos como o RFID, Radio-Frequency Identification. Uma das tentativas perceptíveis, por exemplo, foi eliminar o Kanban físico através da disponibilização nas telas por meio da integração com o MES (COTTYN et al., 2011; POWELL, 2012; WANG et al., 2012).

Estas ferramentas podem ser úteis para as operações de equipamentos e manuseio de materiais, reduzindo custos desnecessários com mão-de-obra e facilitando a busca pelo resultado ótimo das decisões (COTTYN et al., 2011; WANG et al., 2012).

Em oposição, Halgari et al. (2011), também sugerem que dependendo das formas de implementação e das lógicas utilizadas de produção puxada/empurrada, os sistemas ERP podem representar um obstáculo na disseminação de algumas práticas como o Lean Manufacturing, e provocar o acúmulo de inventário, além da redução na velocidade da produção.

Finalmente, em sua obra, Cottyn et al. (2011), introduziram a ideia do mapeamento da cadeia de valor eletrônico ou eVSM, Value Stream Mapping, e as ferramentas disponibilizadas, como as planilhas, para a disponibilização visual das listas de progressos e mapeamento do fluxo de produção. Contudo, os autores ressaltam que o MES poderia contribuir fornecendo informações relevantes para a gestão do $e V S M$ e até mesmo validar os resultados observados manualmente para comparar atividades de produção.

Para esta pesquisa será utilizado o método qualitativo com caráter exploratório no sentido de averiguar com maior profundidade a percepção das empresas em relação à aplicação dos sistemas MES integrados aos sistemas ERP.

A estrutura do trabalho é composta pela introdução ao tema abordado e discussão do problema de pesquisa e objetivos. No próximo capítulo faz-se a revisão bibliográfica sobre o assunto, seguida pela formulação das proposições. Em seguida parte-se para a apresentação da metodologia empregada, detalhamento da coleta de dados, para então iniciar a análise dos resultados obtidos e finalizar a pesquisa através de discussões e conclusões. 


\subsection{Problema de Pesquisa e Objetivo}

A justificativa de pesquisa é baseada no fato de que novas tecnologias como o MES e integrações com os sistemas ERP têm sido cada vez mais presentes em indústrias de manufatura discreta para solucionar as complexas questões do chão-de-fábrica, tendo como premissa as múltiplas variações de operações e combinações presentes nas manufaturas discretas.

Além disso, percebe-se que a automatização do processo de coleta de dados pode reduzir o número de falhas e dados inconsistentes. O projeto pretende esclarecer sobre algumas soluções que têm sido aplicadas na realidade das corporações no que diz respeito à redução de custos industriais.

Portanto, o presente trabalho tem por objetivo principal responder a seguinte questão de pesquisa: Como o uso do sistema MES e sua integração com os sistemas ERP podem contribuir para a redução de custos operacionais em indústrias de manufatura discreta?

Como objetivos específicos, o projeto procura explorar os métodos utilizados por determinadas indústrias em ambiente em que esteja presente uma combinação entre os elementos do sistema ERP e o software MES ou a presença do MES isoladamente a fim de avaliar a aplicação de ferramentas através do conceito de MES contextualizadas no ambiente de sistemas de ERP em relação à redução de custos. Outro objetivo específico é averiguar os obstáculos observados no uso do sistema MES, além de observar fatores em comum notados em cada empresa.

Para aprofundar na problemática deste projeto, foi sugerida a aplicação da metodologia por meio de estudos múltiplos de casos preferencialmente entre gestores que atuem em empresas nacionais do segmento industrial as quais adotem o conceito de manufatura discreta. Assim foi possível delinear um recorte das organizações em seus diversos perfis e áreas de atuação.

\section{Experiências anteriores na implementação de sistemas de ERP e MES}

Em razão do envolvimento do próprio autor na implementação de sistemas, serão ilustrados dois exemplos práticos que foram utilizados como subsídios na elaboração do projeto de pesquisa que resultou nessa dissertação. 
A primeira visita em uma grande fábrica do setor de cosméticos possibilitou aferir algumas observações sobre os coletores automáticos de dados no chão-de-fábrica. A empresa multinacional possui diversas fábricas no país e centros de distribuição que abastecem inúmeros pontos de venda no atacado e no varejo e possui uma vasta gama de linhas de produto.

$\mathrm{Na}$ empresa, estes equipamentos auxiliam na coleta online de dados e contribuem para a medição dos tempos decorridos em cada etapa desde o recebimento do insumo, processo de transformação e despacho/embarque do produto acabado para expedição ao cliente.

O apontamento automático construído por diversas integrações via webservice pode trazer contribuições como o controle online via dashboards, telas touch-screen, distribuídos ao longo da fábrica para que os tempos de processo pudessem ser reduzidos, comunicação via Portais Web, identificação de gargalos ou bottlenecks. Pode-se efetuar o cálculo da hora-homem por apontamentos individuais e manuais e hora-máquina por apontamentos em conjunto.

Diferentemente, para o controle dos custos diretos de matéria-prima, há um controle bastante assertivo, sendo possível o controle detalhado inclusive por código de barras, leitores de rádio frequência, travas automáticas para faturamento em caso de divergências e baixas de materiais em cada etapa do processo produtivo por meio de integrações com balanças, e empilhadeiras, mantendo a rastreabilidade do consumo de estoque.

Outro ponto notado é que embora as empresas possuam diversos sistemas disponíveis para melhorar o controle dos processos e organizar os dados de forma unificada, os dados podem ser distorcidos com a realidade por não haver um parâmetro em comum, que possa ser medido em tempo real, por isto a necessidade de sistemas diferenciados.

A seguir, os apontamentos de produção executados de forma manual, podem reportar informações inconsistentes e divergentes da realidade. A consequência recai sobre o cálculo do custeio real de produção, no que se refere ao cálculo dos custos diretos de mão-de-obra ou fabricação.

Outro exemplo foi evidenciado em uma indústria gráfica em que houve a implantação do MES. A implantação do sistema demandou a adaptação de uma série de processos que levaram a redução dos custos.

A reposição de matéria-prima como bobinas e tintas foi revista. No caso da bobina, por exemplo, foi solicitada a alteração na pesagem de todos os seus componentes e diferenciação do peso bruto líquido com o bruto, assim foi possível identificar as causas de desperdícios de materiais e técnicas para reduzir os desperdícios, para alimentar o sistema MES.

Além disso, o próprio armazenamento das bobinas teve de ser revisto para que pudesse acompanhar um layout (ocupação do espaço físico) mais otimizado para a pesagem e 
movimentação das bobinas, incluindo o seu empilhamento. A seleção dos equipamentos e recursos de empilhadeira e a disposição para a leitura do código de barras (etiquetas) para baixa de material foi revista da mesma forma. O recebimento das bobinas pelo fornecedor nas docas foi otimizado para a pesagem correta de matéria-prima.

Outra percepção é poder distinguir o tempo de virando, com o tempo de ajuste de máquina além de mensurar os scraps, que também fará parte do custeio como sucatas.

A observação destes exemplos originou o interesse em aprofundar o estudo em sistemas orientados a coleta de dados e seus impactos específicos sobre a redução de custos, porém em empresas com manufatura com grande variedade de materiais e operações. 


\section{FUNDAMENTAÇÃO TEÓRICA}

Esta fase do estudo procura apresentar as principais referências que subsidiam a pesquisa por meio de teorias desenvolvidas a partir de outros estudos relacionados.

A finalidade é que sejam discutidas as principais referências que compõem o chamado estado da arte no assunto pesquisado. As referências bibliográficas não apenas estimulam a construção da fundamentação teórica, mas também são de suma importância para a análise de resultados obtidos na pesquisa.

Como alicerce para este estudo, o levantamento de referenciais teóricos será basicamente dividido entre três etapas distintas. Na primeira fase será definida a importância estratégica exercida pela Tecnologia da Informação.

Na próxima etapa, será discutida a importância dos sistemas de informação, em especial, os sistemas e o seu papel dentro de uma organização e neste contexto, relata-se sobre a proporção tomada pelos sistemas ERP nos últimos anos, e sua contribuição para a consistência e disponibilidade de dados.

Em seguida, serão apresentadas bibliografias que definem a relevância dos sistemas para as empresas. Por fim, serão analisados alguns fundamentos teóricos que discutem sobre sistemas de informação ERP e MES.

A pesquisa bibliográfica utilizada nesta pesquisa é baseada na revisão de artigos, dissertações, teses e livros relacionados à definição de sistemas de informação e o papel desempenhado por estes sistemas nas mais diversas organizações.

Inicialmente foram revisadas obras da literatura, incluindo livros e estudos de periódicos, relacionadas ao tema de pesquisa, assim como uma pesquisa detalhada sobre tecnologias vigentes no mercado, em termos de sistemas ERP e MES. 


\subsection{Evolução da tecnologia de informação na gestão da operação}

Em meados dos anos 60, Goldratt (1994) introduziu um novo conceito para a programação da produção do chão-de-fábrica baseado na abordagem de capacidade finita das máquinas. Esta nova técnica ficou conhecida como PFP, Planejamento Fino da Produção. Alguns anos depois, Goldratt (1994) introduziu um novo software no mercado, denominado OPT, Optimized Production Technology.

Este sistema herdava algumas melhorias sobre os sistemas vigentes na época como o MRP/MRP II, no sentido de obter uma melhor integração, aumento de velocidade de processamento, identificação de gargalos e introdução de técnicas japonesas para controle da produção.

Além disso, segundo Goldratt (1994), houve a disseminação do conceito de TamborPulmão-Corda ou o conhecido TPC através do qual era possível chegar a uma sincronização da produção, balancear o fluxo e nivelar a utilização do recurso produtivo.

Conforme entendimento das revisões teóricas, diversos autores relatam sobre o contexto das novas tecnologias designadas para as empresas de manufatura. A Figura 2, adaptada da APICS, American Production and Inventory Control Society, compreende as diversas ações tomadas no decorrer dos últimos anos, e revela o surgimento de novos conceitos tecnológicos dentro do contexto de manufatura, dentre eles, a integração entre o ERP e o MES em cenários de extrema competição global.

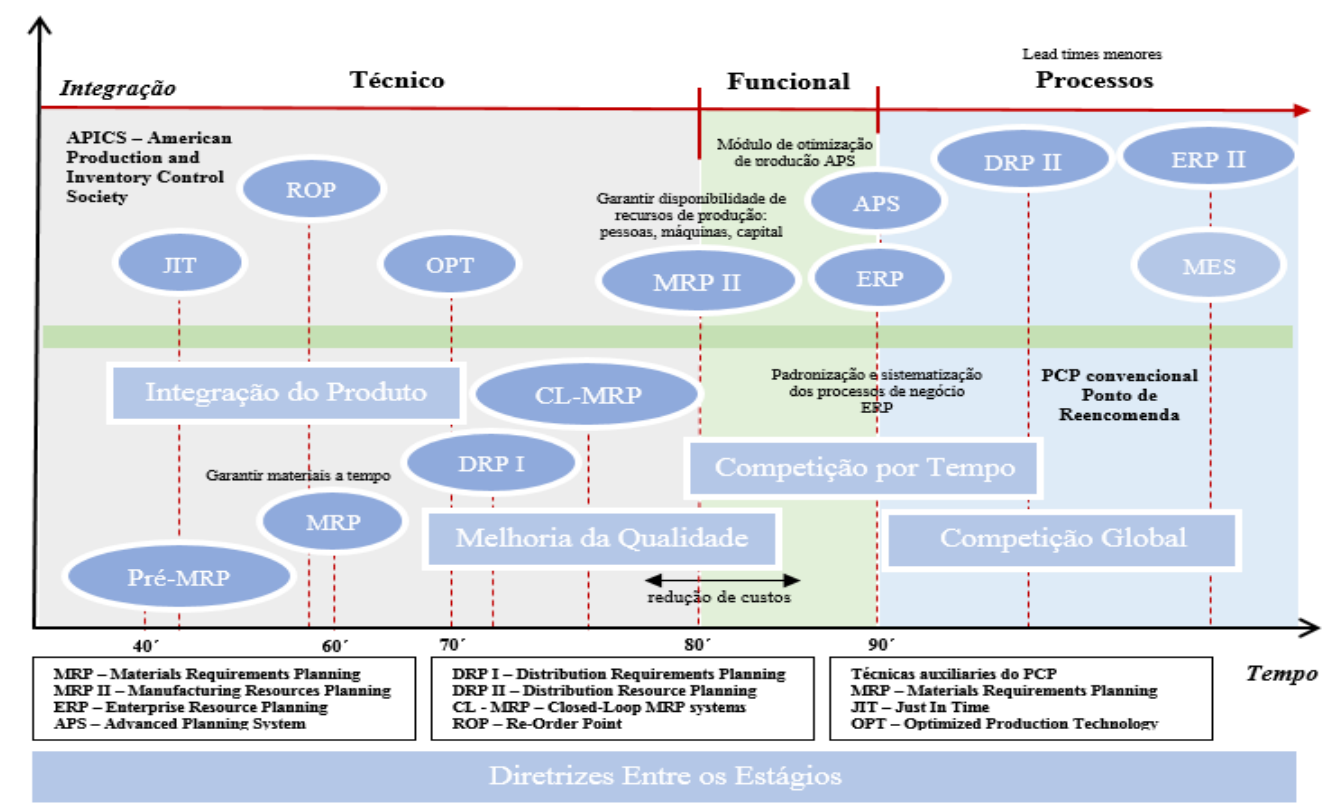

Figura 2 - Evolução da tecnologia e das técnicas auxiliares do planejamento e controle da produção FONTE: Adaptado de JÚNIOR (2009). 
Avançando mais na cronologia das ações e investimento das empresas na última década, nota-se um esforço mais concentrado para o chão-de-fábrica. As informações retiradas podem ser enviadas ao ERP e encaminhadas aos demais elos da cadeia de suprimentos e parceiros de negócios, reforçando ainda mais os diferenciais competitivos diante de um cenário de competição global.

O trabalho proposto por Ferrazi (2012) assume que nos 70, houve um enfoque maior sobre as ações de marketing e por isso as tecnologias promoviam subsídios para o controle e planejamento da produção como o MRP para atender a demanda de forma convincente.

Já nos anos 80 este enfoque passou a ser promovido para a qualidade dos produtos e atendimento de requisitos. Em decorrência disto, houve uma melhoria de controle sobre os processos e custos de overhead. A tecnologia do MRP II foi capaz de fornecer dados de custos mais detalhados e relevantes para a gestão.

Nos anos 90, a competição passou a se dar com foco sobre o tempo. Diante de uma produção dinâmica e globalizada, as indústrias passaram para uma exposição de vários fatores que poderiam alterar os cenários de curto prazo, influenciando o planejamento de toda a cadeia.

Por conseguinte, nos anos 2000, a evolução passou a observar também outros fatores, como a inovação, flexibilidade, manufatura ágil, sustentabilidade e integração das operações, observando custo e velocidade, conforme o modelo cone de areia de Slack e Lewis (2002), sendo o MES foi uma das tecnologias desenvolvidas para tentar suprir as carências.

Na Logística, por exemplo, foi desenvolvido o DRP, Distribution Requirements Planning, que conforme os estudos de Mesquita (2008) é responsável por coletar os dados ao longo da cadeia de suprimentos para aperfeiçoar o atendimento das demandas, por meio da programação da produção aliada a um planejamento de distribuição mais adequado.

Para Banzato (1998), outra figura expressiva é o chamado TMS, Transportation Management System, para ampliar a eficácia no controle da capacidade do transporte e controle de entregas, além do WMS, Warehouse Management System, para obter maior sinergia operacional no gerenciamento da cadeia de suprimentos e controle de rotas e endereçamentos de produtos.

Outro exemplo de evolução agora na área Comercial a ser citado é o CRM, Customer Relationship Management, que conforme acrescentado por Mesquita (2008) é utilizado para ampliar o controle da gestão e relacionamento do portfólio de cliente e alinhamento de expectativas. 
Mais especificamente no setor de Produção podem ser observadas outras formas de evolução na tecnologia. Conforme notado por diversos autores, o CIM, Computer Integrated Manufacturing, é uma tentativa de integrar todas as atividades de produção por meio de informação e automação, garantidas pelas iniciativas de CAD/CAM, Computer Aided Design/Manufacturing, que são conjuntos de equipamentos e sistemas focados em projeto e automação da manufatura e o $\mathrm{CNC}$, Computer Numerical Control, que corresponde às máquinas com sistemas de controle e leitura de instruções.

Finalmente, outras tecnologias desenvolvidas são os SDCD, Sistemas Digitais de Controle Distribuído, DCS, Distributed Control System, os CLP, Controladores Lógico Programáveis, utilizados para os controles de processos de produção, AIS, Automatic Information Systems, MES, Manufacturing Execution Systems, o chamado FMS, Flexible Manufacturing Systems, VMI, Vendor Management Information, EDI, Electronic Data Interchange, SFC, Shop Floor Control, entre outros.

A tecnologia da informação contribui para automatização e sofisticação do PCP, e tornálo um processo cada vez mais robusto. Tanto o ERP/MRP quanto o próprio MES são elementos direcionados para melhorar o controle e a gestão da programação planejamento e controle de produção, permitindo a integração entre sistemas de diversas áreas.

Em síntese, as tecnologias foram agrupadas no esquema da Figura 3 a seguir, em que foram categorizadas em pilares de controle, com perspectivas mais operacionais, planejamento, com objetivos de execução e planejamento da produção estruturados, e finalmente a execução da função de negócios, com diretrizes mais orientadas a estratégias das empresas. 


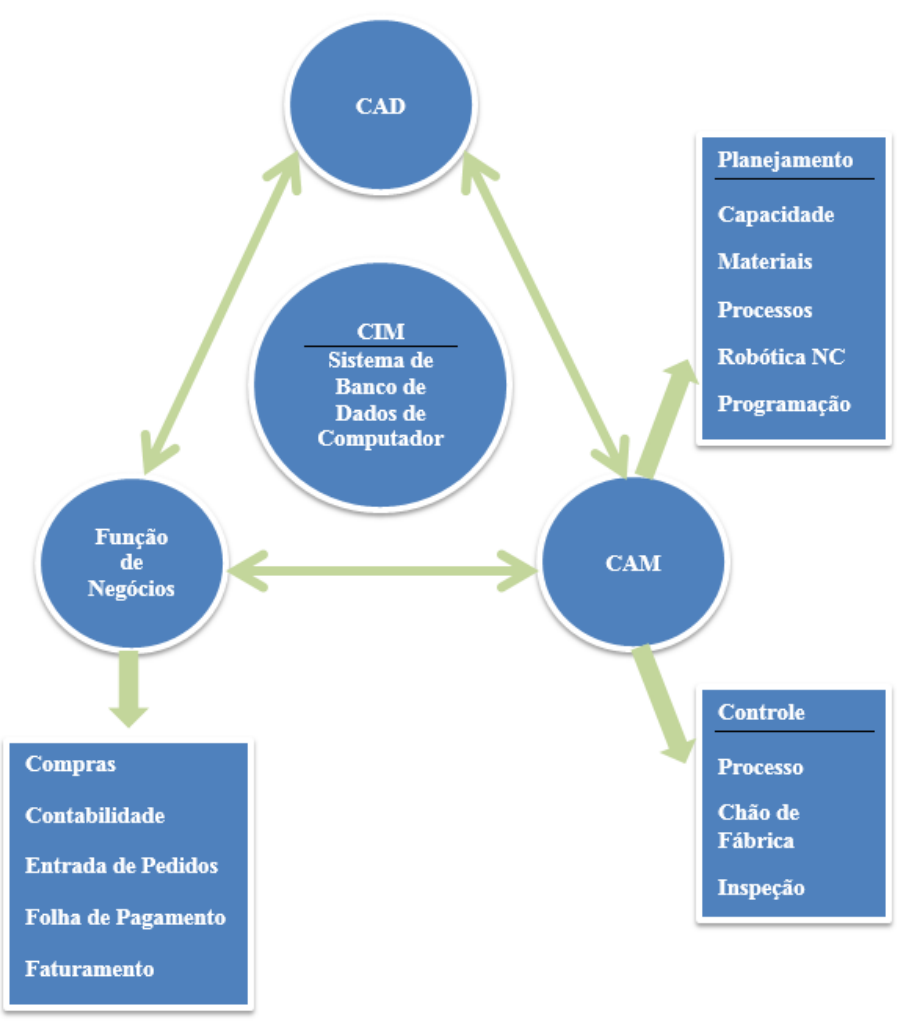

Figura 3 - Integração entre as diversas iniciativas tecnológicas FONTE: Adaptado de GAITHER; FRAZIER (1999).

\subsection{Sistemas ERP}

No entender de Laurindo (2008), tem sido cada vez mais notória a importância assumida pelos sistemas ERP como forma de integrar os vários processos existentes em uma corporação, resultando em uma visão global para a tomada de decisões. A ferramenta ERP é um sistema integrado de dados e processos utilizado para o planejamento de recursos, com o intuito de reduzir custos, otimizar o fluxo, e auxiliar nas atividades direcionadas à gestão da empresa.

Conforme exposto por Gaither e Frazier (1999), os sistemas ERP consistem em diversos módulos adquiridos de forma separada de modo que possa auxiliar na administração de inúmeras atividades em diversas áreas funcionais de um negócio.

Os sistemas ERP são capazes de automatizar processos de manufatura, organizam informações fiscais e modernizam vários departamentos corporativos, como a área financeira. Dentre algumas características notificadas pelo ERP podem ser listados, de acordo com os autores Sangster et al. (2009), tais como elevação da produtividade, possibilita melhorar os processos entre departamentos, e confere maior flexibilidade nas operações. 
O autor Bernroider (2008) ressalta também a magnitude sobre o domínio dos processos de negócios e tecnologias para garantir uma implementação segura de sistemas ERP.

Dependendo de cada tipo de negócio, dimensão e especificidade é oportuno que o ERP esteja integrado com outros sistemas que sejam capazes de acompanhar cada atividade segundo o papel desempenhado na cadeia de valor da empresa, conforme definido por PORTER (1994).

Georges (2010) recomenda que os sistemas de informação como o ERP podem ser implementados para a execução de uma vasta gama de funções de negócios, como a própria logística, mas em contrapartida podem também ser utilizados em algumas funções específicas, no caso da manufatura, para o seu planejamento (Liu et al., 2008). Souza et al. (2010), também citam a importância do ERP na gestão da logística e na gestão da cadeia de suprimentos. Conforme proposto por Georges (2010) é oportuno reconhecer os processos e adaptar o sistema ERP aos processos das organizações.

Choin et al. (2013) relacionam a existência dos chamados Fatores Críticos de Sucesso para descrever a adoção do ERP. Tais fatores complementam a necessidade de um forte e detalhado planejamento, de uma maneira progressiva, através de uma comunicação substancial e intenso treinamento ao longo de toda a empresa.

Powell et al. (2013) relacionam em seus estudos que o ERP por vezes possui um acúmulo de dados que não são de nenhuma maneira utilizados seja para o controle seja para a melhoria de processos. Outro fator que merece destaque é a existência de lacuna entre o processo de negócio atual e aquele desenhado para nos moldes do ERP.

De acordo com os estudos de Tenkorang e Helo (2011), as empresas demonstram altos índices de satisfação com o ERP e evidenciam interesse em buscar novas extensões de funcionalidades disponibilizadas pelo ERP com outros conceitos, processos e sistemas.

Já para Françoise e Pellerin (2009), durante a instalação do ERP todos os processos de uma empresa são investigados. Deste modo, é preciso atentar-se para o gerenciamento de riscos, dado o alto nível de incerteza encontrado nestes tipos de projetos.

Para os autores, alguns fatores devem ser considerados como críticos durante a instalação do ERP. Por exemplo, é necessária a alocação de uma equipe de projeto específica para condução correta do gerenciamento e da comunicação entre os participantes, garantindo o envolvimento do usuário final. 
Além disso, é necessária a disseminação de uma forte cultura organizacional por parte do top management para gerenciar mudanças na estrutura da empresa, com objetivos de longo prazo. Os gestores necessitam também revisar constantemente o Plano de Negócios, otimizar os processos de negócios e esboçar possibilidades de customizações nos sistemas, para aprimorar o desenvolvimento dos softwares e monitorar a performance dos sistemas.

Conforme observado por Davenport (1998), a implementação do ERP pode resultar em riscos ocasionados por dois fatores. O primeiro pela perda de diferenciação para cada circunstância deparada em um ambiente dinâmico de produção e o segundo pelos ganhos de eficiência em detrimento da perda de eficácia. Tal constatação pode induzir a um questionamento em relação à tratativa adotada no que se refere à melhor estratégia empregada para a redução de custos.

Contudo, para Sangster et al. (2009), um dos argumentos que podem ocasionar o fracasso nas implementações de ERP, é a adoção de filosofias tradicionais da área da Tecnologia da Informação ao invés da filosofia de aplicação orientada de forma mais robusta ao ERP.

Ou seja, não contemplaram todas as particularidades que poderiam ser obtidas através do desenvolvimento e implementação de um sistema integrado com as operações e processos de toda a organização, como a Contabilidade, Manufatura, Gerenciamento da Cadeia de Suprimentos entre outros.

Em suma, a evolução do ERP contribuiu muito para que novos adventos tecnológicos pudessem ser desenvolvidos no sentido de melhorar o controle e foi um dos grandes exemplos de aplicação da tecnologia da informação na gestão da operação.

\subsection{Sistemas MES}

Há extensivos esforços sendo executados no sentido de colaboração e integração do uso da informação no planejamento da produção, de modo que o uso sistemático de programas de computador em ambientes de manufatura proporcione um aumento considerável do valor agregado, transparência, flexibilidade e produtividade (KLETTI, 2007; GRIEVES, 2006).

Nesse contexto, é possível debater também sobre a crescente demanda pelos chamados softwares MES, cuja proposta é baseada na aplicação de soluções capazes de gerenciar os dados extraídos automaticamente do chão-de- fábrica. 
O mercado do MES tem crescido em ritmo acelerado na última década, atingindo grandes marcos em seu ápice, no ano de 2006 e com altos índices de aquisições e fusões de empresas especializadas no mercado. Contudo, especialmente para o setor aeroespacial esperase um maior investimento do MES, conforme haja uma gradual recuperação deste setor (WHITLOCK, 2012; OWCZARCZYK, 2010).

A ISA, International Society of Automation, desenvolveu uma metodologia padronizada que propõe uma sugestão para oferecer subsídios e preencher a lacuna entre o negócio e os processos funcionais. De forma semelhante os estudos da MESA, Manufacturing Enterprise Solutions Association (1997) apresentam de forma mais estruturada os elementos que constituem o ambiente em que o MES está inserido visando principalmente à redução dos gastos administrativos, obtenção de rastreabilidade e genealogia, e logo, a análise de desempenho (CAMPOS e MIGUEZ, 2011; BERTI, 2011).

A definição de MES consiste em soluções desenvolvidas para aprimorar o controle dos dados de todas as etapas da linha de produção em tempo real, através do alinhamento entre as métricas de desempenho e o monitoramento das informações, além do foco na execução e controle da produção e de processos (LIU et al., 2008, CORRÊA, 1997).

Todas essas ideias fundamentam a aplicação do MES que surgiu como uma plataforma capaz de prover tanto informações da produção quanto as de materiais, orientada ao controle de produtos e as soluções existentes nos sistemas de chão-de-fábrica (BAUER e STOETER, 2010; DEUEL, 1994).

Indo além e exemplificando o trecho acima, as principais atividades que compreendem a execução e o controle no chão-de-fábrica são a liberação e planejamento das ordens de produção, o sequenciamento das operações e o apontamento da produção, traduzindo estes dados em ações detalhadas e executáveis com propósitos de verificação e rastreamento das ordens de produção (FERNANDES, 2010; ROLÓN e MARTINEZ, 2012).

Ainda nesta linha de raciocínio, é possível entender que o MES pode desempenhar a responsabilidade pelo preenchimento do gap entre o alto nível de gerenciamento de informações encontrado no ERP para a integração das empresas e os sistemas de controle que gerenciam o chão-de-fábrica, de forma que se reduza esta lacuna.

Conforme citado por Banerjee et. al (2013), o MES seria definido como um nível intermediário entre o ERP e os sistemas de controle a nível de chão-de-fábrica. Além disso, o MES tem se apresentado como uma solução eficaz para a automação industrial, principalmente por propiciar uma estrutura de customização flexível. 
Dentre os gaps que podem ser mencionados, há uma crescente demanda pelo estudo detalhado do controle dos custos de manufatura os quais estão diretamente dispostos com a exposição a diversos fatores e variáveis que originam oscilações e distorcem a real situação do processo de manufatura.

Outros autores como Cottyn et al. (2011) apontam que os sistemas de Controle de Produção e Processos foram desenvolvidos para aumentar o controle sobre as atividades de manufatura diárias resultando em produtos acabados com qualidade.

Em contrapartida, o ERP é útil para manter várias informações relevantes de negócio atualizadas e fornecer suporte aos processos administrativos. No entanto, a dificuldade encontrada para integrar os múltiplos pontos de diversos sistemas, levou os instaladores de software a compactar os diversos componentes de gerenciamento e execução múltiplos em uma única solução integrada tal como é conhecido o sistema MES.

Muitos fornecedores do próprio ERP e sistemas de automação têm entrado no mercado do MES e alguns fornecedores de MES, como o SAP ME, têm se especializado em nichos focados, dentre eles o mercado da manufatura discreta. Alguns dos principais fornecedores do MES que podem ser mencionados incluem a GE Intelligent Platforms, Invensys, Oracle, Rockwell Automation, Schneider Electric, entre outros (FERRAZI, 2012; WEIL, 2011).

A Figura 4 contempla justamente o fluxo de informações entre os sistemas operacionais e os sistemas gerenciais. Através de sistemas SCADA, Supervisory Control and Data Acquisition, os dados coletados no ambiente de produção são captados e disponibilizados em monitores para que os supervisores possam acompanhar a produção.

De posse destes dados, o MES captura os dados e atualiza a programação detalhada da produção em um banco de dados centralizado, organizando os recursos disponíveis para a execução do trabalho e verificando os impactos de eventuais mudanças no ambiente produtivo em termos de programação. Por fim, as ordens planejadas têm seus status atualizados para que o ERP possa ser alimentado, para consulta gerencial e repasse de dados aos clientes, fornecedores e colaboradores internos, facilitando o planejamento e a tomada de decisões no nível organizacional. 


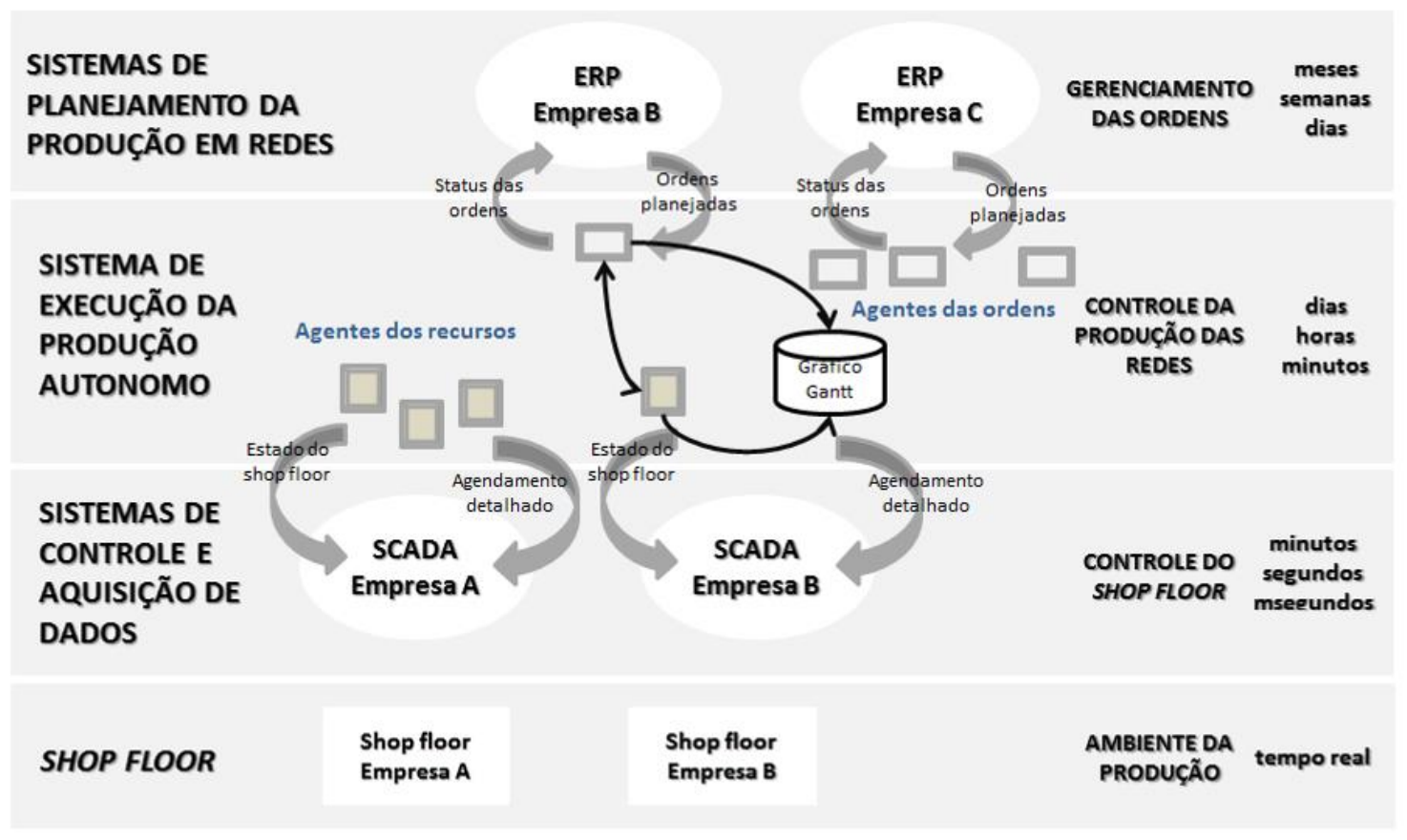

Figura 4 - MES autônomo para integração empresarial

FONTE: Adaptado de ROLÓN; MARTINEZ (2012).

As elevadas quantidades de informações presentes ao longo da empresa podem favorecer o uso de sistemas dispersos. A falta de integração entre os múltiplos bancos de dados podem ocasionar problemas em relação ao tratamento de dados nas organizações. Todavia, os investimentos em integração de processos, organização e planejamento da produção podem ser pagos rapidamente. (ZHAO et al., 2011; FRAZER, 2011).

De acordo com Lee et al. (2012), o MES é empregado basicamente pelos trabalhadores de job shop e pelos gerentes de manufatura. Os principais requisitos para estes sistemas seriam simplicidade de interface com usuário e fácil manuseio das operações.

Para compreender o contexto em que o MES está inserido, a Figura 5 representa os diversos níveis existentes de controle da produção, condizentes com a formulação de normas e padrões de sistemas estabelecidos pela ISA, a ISA 95.

A figura extrai características interessantes de cada nível, desde o operacional conforme os tipos de manufatura atribuídos até os aspectos estratégicos de planejamento, em que a dimensão de tempo passa a ser verificada no longo e médio prazo. 


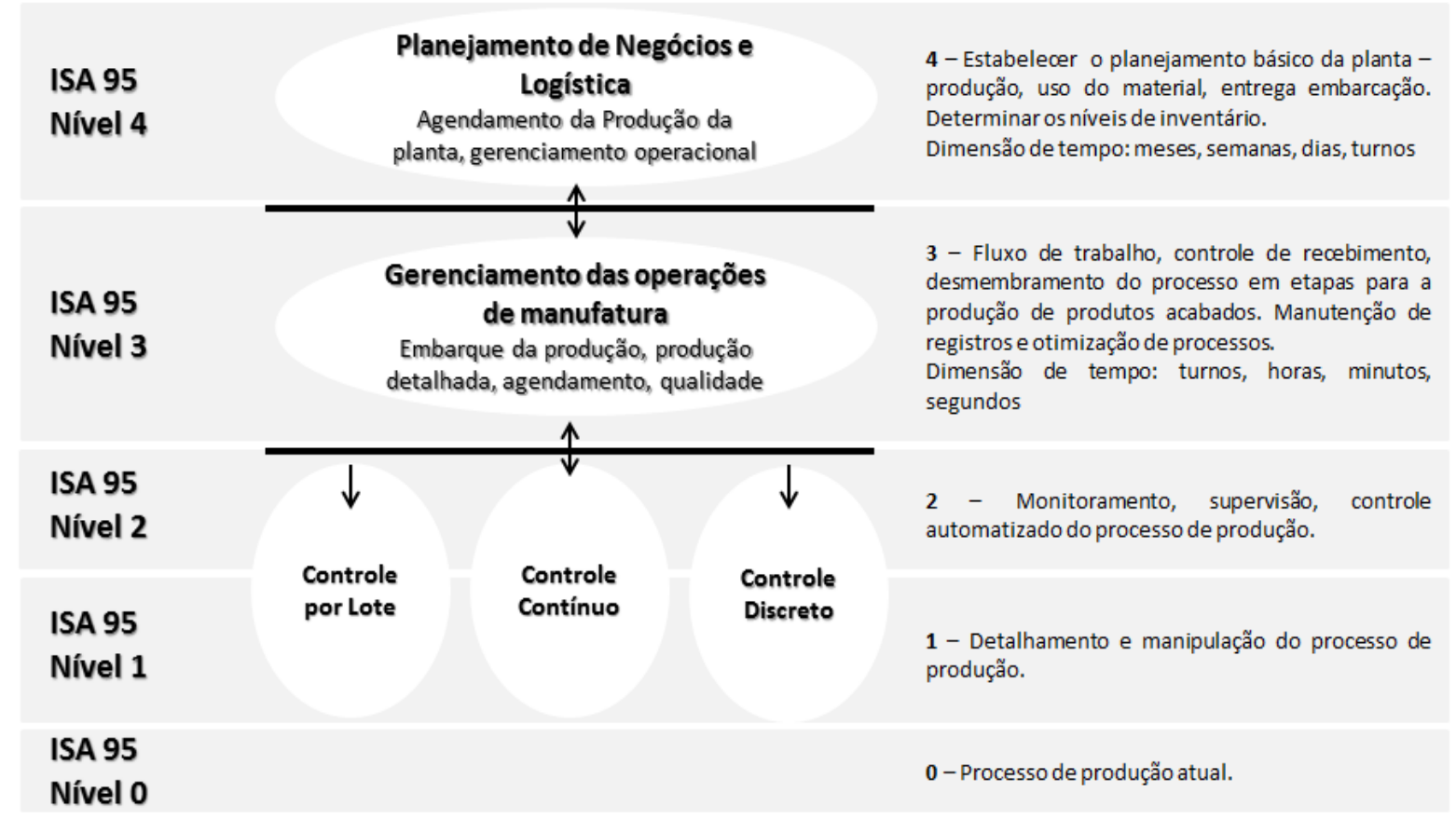

Figura 5 - Modelo hierárquico e funcional ISA

FONTE: Adaptado de BOLTON; TYLER (2008) In FERRAZI (2012).

Os sistemas corporativos geralmente trabalham com o horizonte de tempo baseado em meses/semanas para o planejamento estratégico. Já o planejamento da produção tende a se basear no limite de semanas ou até mesmo dias, enquanto o planejamento detalhado deve verificar as alterações e decisões tomadas em minutos e turnos de produção. Finalmente, os sistemas de automação trabalham com intervalos baseados em minutos e segundos, para controle de máquinas e sistemas de controle (KLETTI, 2007; DEUEL, 1994).

Cabe ressaltar que para He (2012) e Maule (2010), mesmo que a intenção do uso do MES seja demonstrar o fluxo da informação no processo como um todo, é possível extrair informações específicas de um produto ao longo da cadeia produtiva.

Outra atribuição citada pela empresa de software DBA (2011) é que os sistemas devem verificar constantemente os trabalhos executados por cada operador, e rastrear as operações que contenham erros ou fora de ordem.

Por essas considerações, diversos estudos enfatizam a necessidade de se considerar as condições reais fornecidas pelos equipamentos e as variabilidades de processo, uma vez que as condições iniciais podem sofrer modificação no decorrer do tempo. O MES estaria preparado para indicar uma programação detalhada de atividades, responder aos eventos incertos e aleatórios e também adaptar planejamentos elaborados a determinadas circunstâncias, como falta de material e quebra de máquinas (GAMA, 2011; BERTI, 2011). 
Nas palavras de Stano et al. (2011), os papéis atribuídos ao MES podem ser divididos em duas frentes. Enquanto a primeira frente refere-se às funções core, a segunda frente trata de funções secundárias praticadas pelo MES. O uso da informação é de grande valia na análise e simulação do fluxo da fábrica.

As informações de controle extraídas do chão-de-fábrica por meio de inúmeros métodos como leitores de código de barras, apontamentos, CLP, sistemas supervisórios, são capazes de criar um banco de dados no sistema MES.

Nos estudos de Adler et al. (1995), foi constatado que através de terminais ao longo do chão-de-fábrica, os operadores podem ter fácil acesso aos dados o que facilita a inserção e o acompanhamento de dados através de integrações com leitores de códigos de barras e tecnologias de RFID, reduzindo a margem de erros. Através de gráficos e comandos é possível checar o ambiente produtivo, conforme as ações no tempo da própria consulta.

“Os ícones possuem cores que indicam o estado de operacionalidade de cada máquina. Através de uma simples busca, o usuário do sistema pode também obter um apontamento visual do ponto monitorado em que está sendo processado um determinado lote" (ADLER et al., 1995).

Através de sinais emitidos em intervalos de tempo parametrizados via interface, as operações são bloqueadas caso qualquer anormalidade seja detectada no processo, considerando as etapas sequenciais da produção. Neste contexto, é possível reduzir o risco relacionado à montagem incorreta de peças ou utilizar peças incorretas dentro de uma operação (GAMA, 2011).

É possível observar nos monitores de cada estação a montagem da peça e o local exato onde ocorreu a anormalidade e disparar mensagens de ações necessárias aos responsáveis através dos fluxos de trabalho ou workflows.

O MES pode ser entendido também como ferramenta para a disseminação, sob uma linguagem única, entre diversos setores desde o comercial até o de manufatura. Para se tornar mais competitiva, as empresas podem compreender a cadeia de valor; estabelecer preços e custos alvo, aperfeiçoar a integração com ambientes externos e obter maximização de lucro no longo prazo (LIU et al., 2008).

Para os autores Deuel (1994), Kletti (2007) e Stano et al. (2011), os principais atributos encontrados no MES são elencados no Quadro 1 abaixo. Os autores reforçam ainda que a coleta das informações de sistemas tradicionais de controle de processos pode ser uma tarefa exaustiva e ainda incorre no risco da falta de correlação entre os dados, além de possuir um foco maior no controle de centros de trabalho, em detrimento do controle atualizado dos produtos. 
Quadro 1 - Principais atributos oferecidos pelo MES

\begin{tabular}{|c|c|c|}
\hline \multicolumn{3}{|r|}{ PRINCIPAIS ATRIBUTOS OFERECIDOS PELO MES } \\
\hline \multirow{2}{*}{$\begin{array}{l}\text { FUNÇÕES } \\
\text { PRINCIPAIS }\end{array}$} & 1 & Integração do processo produtivo pelo sistema de planejamento \\
\hline & 2 & Aprimoramento contínuo do processo \\
\hline & 3 & Gerenciamento das estações de trabalho \\
\hline & 4 & $\begin{array}{l}\text { Sincronização dos elementos: material, pessoal, equipamento, processos e } \\
\text { instalações. }\end{array}$ \\
\hline & 5 & Gerenciamento de Contingências \\
\hline & 6 & Cálculo automatizado de taxas e performance \\
\hline & 7 & Avanços tecnológicos \\
\hline & 8 & Elevação da satisfação dos clientes \\
\hline & 9 & Redução dos custos de produção \\
\hline $\begin{array}{c}\text { FUNÇÕES } \\
\text { SECUNDÁRIAS }\end{array}$ & 10 & Gerenciamento da manutenção e qualidade \\
\hline & 11 & Atendimento de requisitos legais das indústrias \\
\hline & 12 & Redução do time-to-market \\
\hline & 13 & Aumento de poder dos operadores \\
\hline & 14 & Desenvolvimento de interfaces amigáveis aos usuários \\
\hline & 15 & Tracking de produtos \\
\hline
\end{tabular}

FONTE: Adaptado de DEUEL, 1994; KLETTI, 2007; STANO et al, 2011.

Estudos anteriores como os de Vanderlei (2010) também verificaram a implementação do software MES em empresas de manufatura discreta, comparando as performances obtidas antes e depois da instalação deste sistema e também fornecendo subsídios para o aperfeiçoamento de sistemas de controle em manufaturas discretas.

A pesquisa de Vanderlei (2010) procurou investigar as percepções dos gestores de manufatura em relação ao MES, e obteve algumas conclusões após a análise da pesquisa, conforme descrito abaixo:

\section{ANÁLISE DAS OPERAÇÕES ANTES DO MES}

Os apontamentos eram realizados em planilhas, em papel físico ou através dos sistemas de informações gerenciais, dificultando tais operações. De forma geral, pode-se entender que houve baixo índice de difusão do MES e também que os lançamentos eram conduzidos de forma incompleta. 
Dados volumosos, escassos em precisão e de difícil interpretação. Falta de informações para apuração das causas de retrabalho e geração de refugos, gerando processos ineficazes e instáveis.

\section{UTILIZAÇÃO DE EQUIPAMENTOS}

Foi averiguado na pesquisa que o uso dos equipamentos apresentava baixo índice de qualidade, comprometendo o planejamento da produção, aumentando o tempo investido em ajuste de máquinas e atividades que não geravam valor efetivo. A alocação de equipamentos e recursos para manejá-los eram subdimensionados.

\section{PROVEITOS GERADOS}

No geral, o sistema MES propiciou proveitos tanto para os usuários internos quanto para os próprios clientes. Em relação aos clientes, os proveitos revelados estavam relacionados ao acompanhamento de pedidos e posicionamento efetivo em relação à entrega dos produtos no prazo, aumentando sua satisfação. Para a empresa os principais proveitos consistem na redução de custos e no acúmulo de conhecimento de processos e tecnológico.

\section{PERCEPÇÃO DAS OPERAÇÕES APÓS O MES}

Após o uso do MES, a pesquisa revela que as informações, indicadores e relatórios disponibilizados pelo sistema permitiam ilustrar as causas que geravam as perdas e todos os problemas que ocorriam no chão-de-fábrica. Ademais, as percepções indicam que o fácil manuseio do sistema também contribui para a sua disseminação interna.

Em relação à produtividade de máquinas, a pesquisa apontou que a instalação do MES resultou em uma alta pontuação neste quesito.

\section{REDUÇÃO DE CUSTOS APÓS O MES}

Especificamente, em relação à percepção sobre a redução de custos após a implementação do MES, a apuração dos dados permite concluir que $78 \%$ dos entrevistados concordam que o MES contribuiu de maneira significativa para a melhoria dos custos. 
Uma outra forma de se analisar os impactos do uso do MES está relacionada com a análise individual dos atributos/dificuldades percebidos tanto pelos departamentos de produção e de qualidade quanto pelas demais áreas, e a posterior análise dos resultados globais aferidos.

Para esta avaliação, os autores Lee et al. (2011) sugerem a Figura 6 como exemplo. A primeira etapa reside na observação do MES no que diz respeito aos temas de investimentos financeiros, desenvolvimento e participação do usuário. Com base nisso, é possível avaliar a qualidade do MES em geral, assim como a acurácia das informações geradas, obtendo-se assim uma percepção da satisfação do usuário e o impacto na produção.

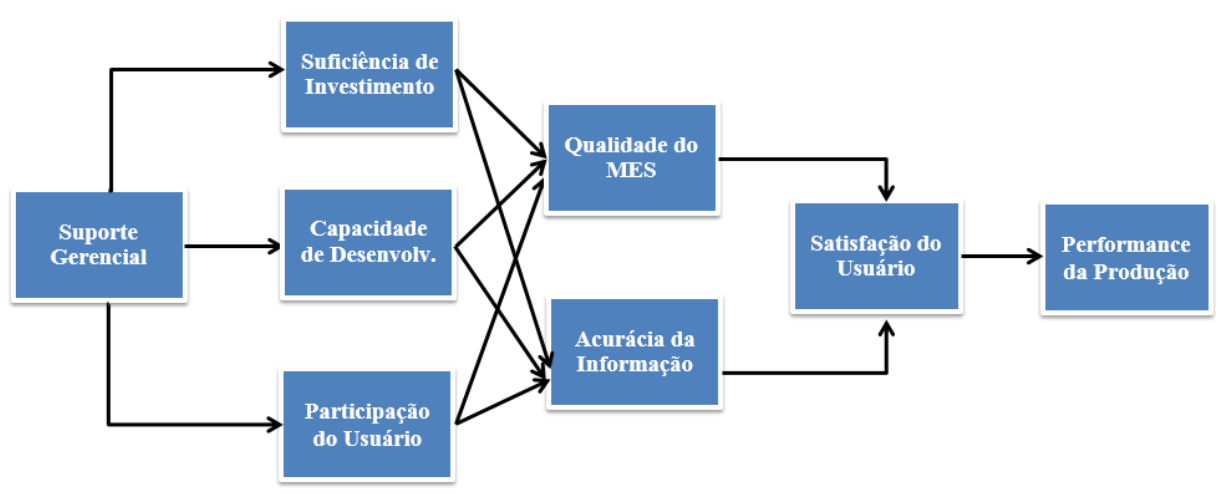

Figura 6 - Modelo de implementação do MES

FONTE: LEE et al (2011).

Cabe também discorrer sobre algumas objeções ao instalar o MES. É possível citar a questão do elevado investimento requerido, tanto em termos financeiros quanto em relação à contratação de equipes e aquisição de treinamentos.

Os investimentos realizados no MES podem trazer resultados principalmente no longo prazo, o que pode dificultar a visualização dos retornos e dos valores gerados por investimentos no curto e médio prazo, além de oferecer soluções muitas vezes intangíveis como a melhoria na comunicação e visibilidade (FERRAZI, 2012).

Ao implementar um sistema MES, os fornecedores e clientes devem se atentar para os chamados fatores contingenciais. Seriam eles, o tamanho da organização, a complexidade do setor de manufatura e o papel estratégico desempenhado, além dos procedimentos de operação padrão. Para atender as necessidades específicas de cada realidade podem ser debatidas as necessidades de customizações ou pequenos ajustes para que o MES seja compatível aos processos e tecnologias da empresa (FERRAZI, 2012; COTTYN et al., 2011; GEORGES, 2010; GAMA, 2011). 
Embora possam existir similaridades entre as empresas é preciso verificar também as especificidades de cada uma delas, os altos preços de instalação e manutenção do MES (COTTYN et al., 2011; UGARTE et al., 2009). Em algumas situações os clientes podem até mesmo ficarem limitados a um fornecedor pela especificidade do software (FERRAZI, 2012).

Já Nyaga (2010) salienta que as atividades de colaboração, como o compartilhamento de informações, relação de esforços mútuos e investimentos dedicados podem contribuir para uma melhor implementação do MES.

\subsection{Integração entre sistemas ERP e MES}

Com o objetivo de definir integrações entre os sistemas (corporativos e chão-defábrica), algumas entidades como a ISA e a MESA estabeleceram normas padrão para o desenvolvimento destas ferramentas de integração entre a empresa e os sistemas de controle, como as Normas ISA S95 e ISA S88. Embora estes padrões sejam sugeridos, as empresas podem optar por utilizar outros métodos conforme suas necessidades (CLARK, 2010).

Oman (2011) defende a ideia de que a integração entre a estratégia de negócios e os processos de produção ocorre por intermédio de interfaces de aplicativos. Muitas interfaces falham em implementar um módulo de produção para monitoramento e controle da produção, dado que o pré-requisito consiste na leitura dos atributos de diferentes aparelhos, máquinas e instrumentos.

Ainda na opinião do autor, os seguintes requisitos seriam necessários para um ambiente de integração entre o ERP e o MES: (1) Organização de recursos e seus status; (2) Classificação detalhada das operações; (3) Organização do produto; (4) Atividades de manutenção; (5) Gerenciamento de processos; (6) Monitoramento de produtos e famílias de produtos.

As etapas que constituem a implantação do MES são sugeridas pela Figura 7. Diante da organização, nota-se novamente o enfoque e a presença da integração entre o ERP e o MES, como elemento chave para a junção do planejamento da produção e a melhoria contínua. 


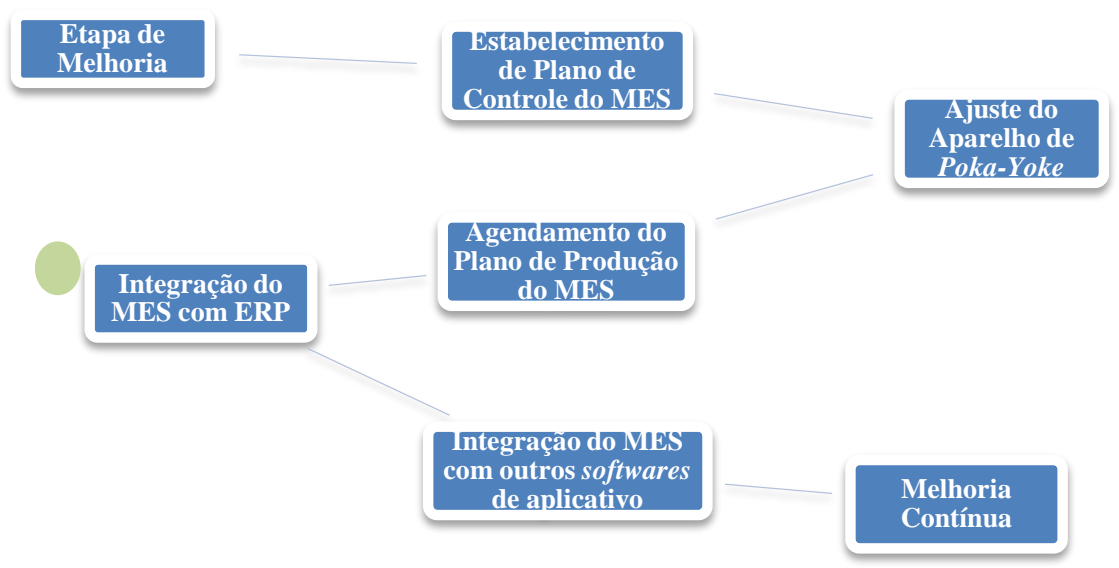

Figura 7 - Diagrama de fluxo da fase de controle na integração entre MES e a metodologia Seis Sigma FONTE: HWANG (2006).

O sistema MES deve ser flexível o suficiente para ajustar as diversas formas de gerenciamento das empresas e ao mesmo tempo suportar diversos tipos de produção. Entretanto, deve ser uniforme para garantir a integração com o ERP.

Os autores Ferrazi (2012), Stano et al. (2011) e Deuel (1994) identificam abaixo as principais particularidades percebidas pela integração entre os sistemas MES e ERP, que possibilitam as seguintes ações:

1) Integração do ERP com a produção, permitindo a sua melhoria e aumento de intensidade no processo produtivo e apoio a decisão;

2) Acesso aos relatórios de produção e detalhamento via drill-down, segundo o equipamento, operadores por máquina e produtos parados na linha de produção;

3) Acesso aos dados de eficiência, margens de erros e controles por operador;

4) Permite o envio de alarmes, em casos de baixa eficiência ou paradas do equipamento, aumentando a disponibilidade de máquinas;

5) Identifica os gargalos de produção e possibilita a apuração de dados estatísticos para localizar a causa-raiz de um defeito;

6) Rastrear lotes no chão-de-fábrica, apresentando seu histórico de produção;

7) Fornecer à gerência da fábrica um sistema que informe em tempo real o status dos setores produtivos para ações corretivas;

8) Consultar apontamento de produção da fábrica por máquina, por funcionário, por lote (diário, semanal e mensal); 
9) Identificação de micro-paradas não perceptíveis que ocasionam geralmente os maiores tempos quando somadas, e que não eram detectadas antes.

Por isso, ao passo que a operação paralela entre os sistemas ERP e o MES parece ser considerada razoável, por outro lado, recentemente identificou-se um desafio que consiste em delinear os limites demarcados e desempenhados por cada tipo de sistema (SCHMIDT, 2011; OMAN, 2011).

Tais sistemas podem em última instância oferecer suporte para funções equivalentes nas duas camadas de desenvolvimento (ERP e MES), ocasionando um alto grau de interconexão, mas também um certo grau de redundância entre os dois sistemas.

Na Figura 8 é recomendada uma representação detalhada dos papéis exercidos por cada um dos sistemas em uma fábrica automotiva, em que há uma sobreposição de papeis desempenhados, como por exemplo, a gestão da mão-de-obra, planejamento, qualidade e controle de equipamentos.

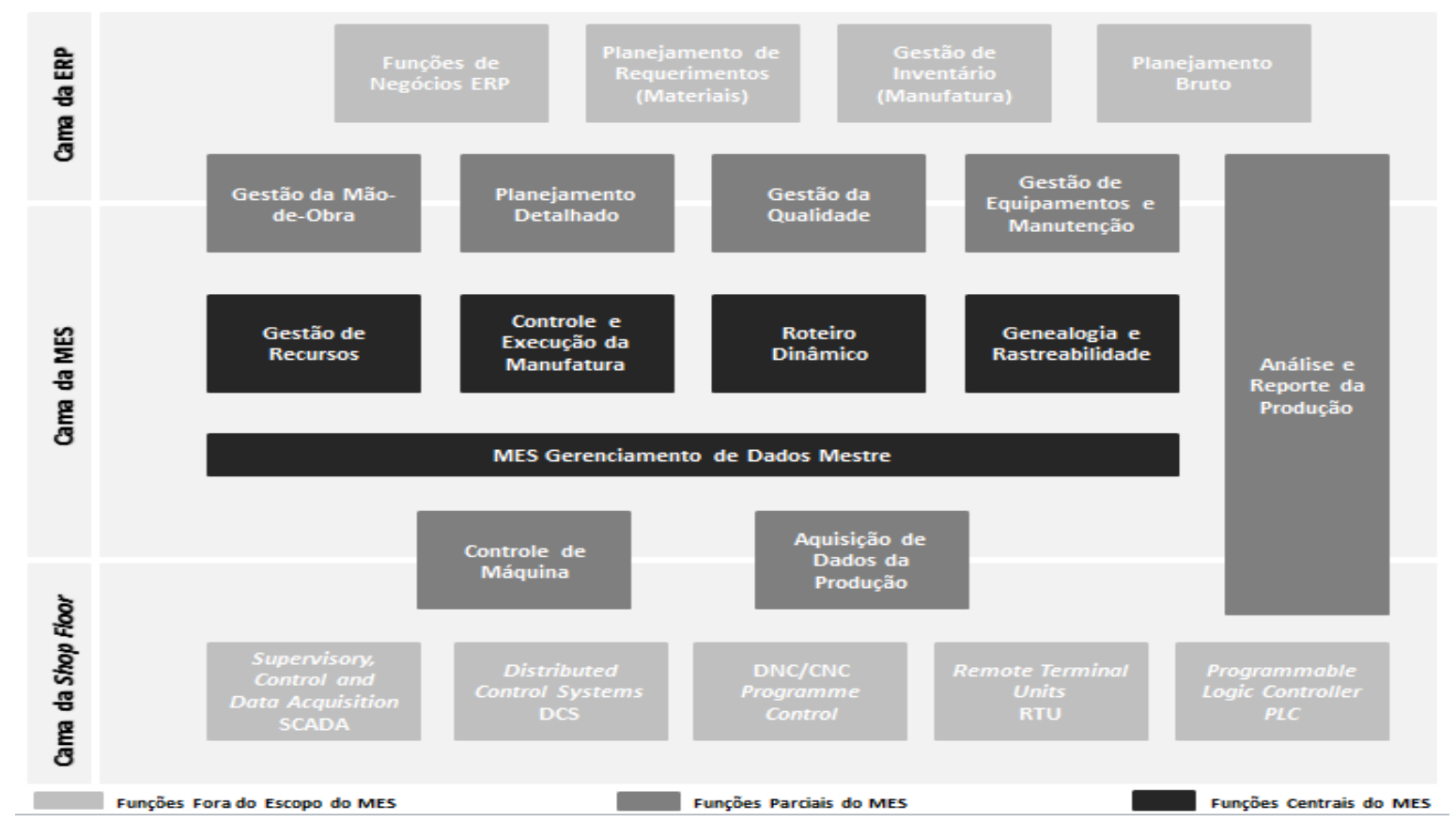

Figura 8 - Modelo de inferência funcional para manufatura integrada na indústria automotiva FONTE: Adaptado de SCHMIDT (2011).

Ainda nesta linha, Schmidt (2011) distingue também e sob um ângulo mais operacional, quais as reais trocas de dados existentes entre os sistemas ERP e MES, e os sentidos em que 
ocorrem. Na Figura 9 são destacados também quais os tipos de dados são trocados entre os sistemas.

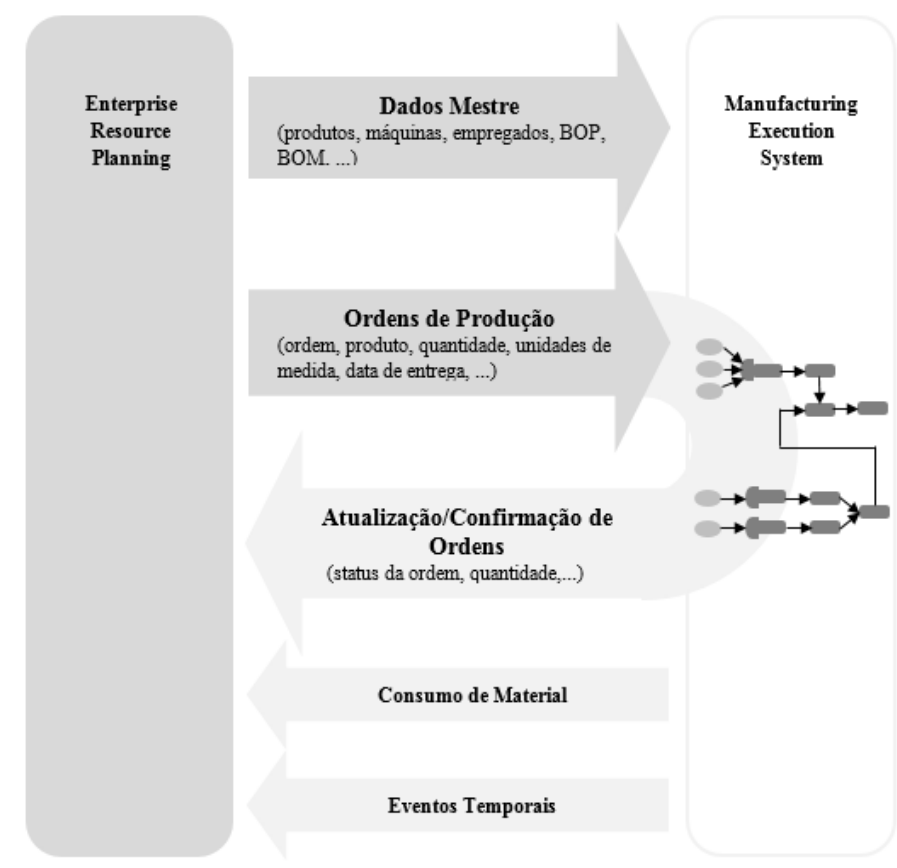

Figura 9 - Conteúdo da interface entre ERP e MES

FONTE: MEYER (2009).

Li (2011) preconiza que o módulo de interface com o ERP é o principal foco do MES. Este módulo é composto por componentes como o SCA, Scheduling Agent, e o STA, Strategy Agent, que são responsáveis por implementar efetivamente o planejamento dinâmico no chãode-fábrica. Através do SCA basicamente desenha-se o planejamento da produção e os agendamentos. E pelo STA é possível reprogramar os planejamentos conforme a dinâmica das alterações percebidas simultaneamente.

Conforme salientado nos estudos de Qifeng (2011), as tecnologias de integração de sistemas, como os integradores de informação, aplicações e processos, são capazes de suportar as ações de colaboração entre o MES e o ERP. De acordo com as características da produção os diversos módulos podem ser ou não ativados para compor o planejamento da produção.

Conforme declarado pelos autores, o MES seria o elemento responsável por direcionar as atividades de produção conforme os planos recebidos pelo sistema ERP, através do módulo de Agendamento da Produção, encaminhando o posicionamento real da produção ao sistema ERP. Para desenvolver um planejamento baseado nos dados gerados pelo ERP os planejadores devem coletá-los e reuni-los o que pode consumir bastante tempo. 
Sobretudo, o MES pode contribuir ao sincronizar automaticamente as atividades de produção conforme as ocorrências imprevistas no chão-de-fábrica, cuja lacuna observada no ERP, poderia ser gerida com um sistema orientado ao controle detalhado da produção. Por estas razões, o MES seria capaz de fornecer ferramentas de gestão tanto para atender clientes de menor dimensão que demandam pequenas peças e clientes de maior dimensão que necessitem de maior quantidade de peças discretas. (LIU et al., 2008; YOUNUS, 2009).

Já Ugarte et al. (2009) mencionam em sua obra que a partir dos adventos tecnológicos como o ERP, as áreas de manufatura buscaram o desenvolvimento de sistemas fabricados internamente pela própria empresa.

Desta forma, seria possível atender as necessidades específicas do setor que não foram consideradas pelos ERP, com foco nos processos macros. Os MRP/ERP fornecem planejamentos que servem como guias para a produção, mas não refletem as mudanças pontuais e as variabilidades no curto prazo dentro do PCP, Planejamento e Controle da Produção, conforme a manufatura do tipo discreta.

No entanto, os autores apontam também algumas dificuldades encontradas no início para implementar o MES, como por exemplo, as variedades de tipos de equipamentos de manufatura que dificultam a conectividade entre os sistemas e o chão-de-fábrica.

O maior desafio atual consiste em rever o processo top-down entre o ERP e o MES, que recebe as ordens originadas dentro do ERP e as envia para execução no chão-de-fábrica. Em novos processos, como a produção Just-In-Time e produção puxada pela demanda, a abordagem de integração tende a ser mais complexa.

Nos estudos de Dai et al. (2012), verificou-se o resultado obtido por meio de uma integração entre as tecnologias MES e RFID. Uma observação importante deste estudo, é que mesmo com o proveito obtido pelo uso do ERP, chegou-se à conclusão de que a origem dos gargalos só foi perceptível através dos estudos feitos no cotidiano das operações de chão-defábrica, ou seja, apenas através dos dados emitidos pelo ERP, provavelmente, estas informações não pudessem ser obtidas e notadas de forma rápida.

O sistema MES, contudo, não tem o papel de substituir nenhum sistema de aplicação empresarial integrada, como por exemplo, o ERP, mas sim estender o escopo de gerenciamento ao chão-de-fábrica de um modo mais detalhado, com foco no planejamento e execução de operações (WANG et al., 2012).

Os estudos de Wang et al. (2012) demonstram que após a integração entre ERP e MES, as lacunas de informações resultantes de procedimentos manuais foram preenchidas ao integrar a tecnologia de RFID, além de aumentar a produtividade das operações. 
Os operadores antes tinham que imprimir o pedido da produção com todas as tarefas a serem executadas, direcioná-lo aos gerentes de produção para execução, coletar os formulários já preenchidos e só então digitar os dados manualmente no ERP.

Os estudos de Choi e Kim (2010), também demonstraram a integração entre os sistemas ERP e o MES, porém sob a óptica de uma arquitetura de sistemas orientada para atender aos conceitos do FMS.

Logo, o sistema MES foi concebido para preencher lacunas muito peculiares ao chãode-fábrica, respondendo questões de curto e médio prazo e oferecendo flexibilidade de programação frente às incertezas do cotidiano. Esta ferramenta pode possibilitar acesso às informações em tempo real, com maior acurácia e precisão, porém as mudanças efetivas só podem ocorrer mediante a aplicação de mudanças nos processos.

\subsection{Manufatura Discreta}

É oportuno também discorrer sobre as dificuldades encontradas para o controle de custos da Manufatura Discreta. A manufatura discreta pode ser caracterizada pelo alto grau de variabilidade das operações e das possibilidades de processamento fabril, constituída de combinações diversas dos elementos referentes às máquinas, roteiros e prazos (JUNQUEIRA, 2003; MCKAY e BUZACOTT, 2000).

A Figura 10 demonstra com detalhes a implantação da integração entre os sistemas MES e ERP dentro de um contexto de manufatura discreta. A primeira etapa consiste na captura de dados, por intermédio de sensores instalados em equipamentos e interfaces homemequipamento. Estes dados são armazenados em bancos de dados.

Posteriormente, os dados são processados pelos sistemas SCADA e encaminhados para a programação no curto e médio prazo para a formação do histórico de produção e transmitidos aos sistemas ERP como dados de planejamento de produção.

Neste sentido o programador exerce um papel fundamental, pois executa a solicitação de alterações e verifica as condições atuais da produção. As informações são transmitidas para a gestão e liberação da produção, convertidas em instruções de trabalho. 


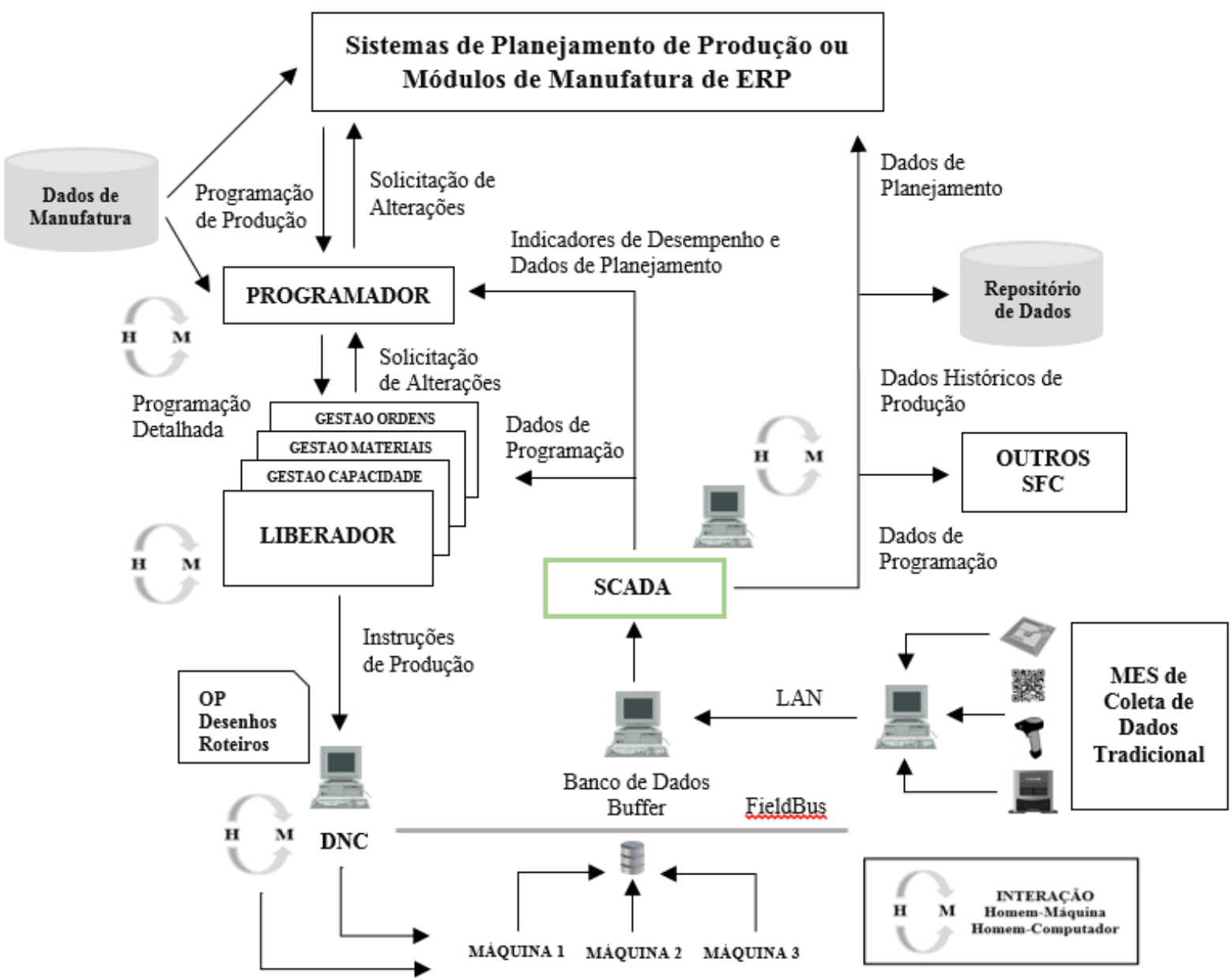

Figura 10 - Modelo funcional de sistema SFC

FONTE: Adaptado de JUNQUEIRA (2003).

Pode haver também uma lista de materiais complexa e extensa, com sincronização de montagem, assim como processos não sequenciais (WANG et al., 2011). Por isso, são demandadas ferramentas que permitam os gestores visualizarem o que está ocorrendo no chãode-fábrica de forma simples e eficaz.

Muitas áreas da manufatura são consideradas como manufatura discreta e, portanto, a importância assumida dentro da economia de vários países e o uso do MES tem crescido nas indústrias dos segmentos automotivos, têxteis, energia e farmacêuticas (WANG et al., 2011; FAST MARKET, 2012).

Alguns exemplos de manufatura discreta que podem ser citados são as indústrias do setor metal-mecânico, fábricas de ferramentarias, semicondutores, eletrônicos, aparelhos médicos, indústria de peças aeronáuticas e navais, instrumento de medição e maquinaria pesada. 
Em estudos realizados por Ferrazi (2012), após a implementação do MES em empresas de manufatura discreta, lote e processamento foi identificado que $92 \%$ das empresas apontaram uma redução no tempo de ciclo da manufatura, obtendo reduções de até $42 \%$ no tempo.

$\mathrm{Na}$ manufatura discreta as partes fluem como peças únicas ao longo da produção, geralmente produzidas por máquinas diferentes. Assim, cada máquina pode apontar informações específicas sobre os tempos de início e término de cada atividade (FERRAZI, 2012).

Normalmente, pode haver mais de uma alternativa para o processamento de uma operação linear ou paralela, com graus de eficiências diferentes. Em geral, este tipo de processo produtivo é caracterizado pelo alto índice de intervenção do operador no processo para acompanhar as etapas e resolver problemas recorrentes, o que contribui ainda mais para aumentar a complexidade para coordenar e alinhar as diversas operações.

Por este motivo, os sistemas de produção cada vez mais apresentam tendências para se adaptarem aos equipamentos que oferecem maior flexibilidade de produto (GAITHER e FRAZIER, 1999). Estas ações servem para atender demandas de lotes pequenos de vários modelos e com alta variedade de personalização para atendimento dos pipelines ou rotas de processamento. A seguir, é preciso identificar um lote de produção de acordo com a data ou horário de produção.

Conforme os argumentos de Correll e Edson (2007), para a produção discreta pode-se resgatar os tempos consumidos em cada operação e também os processos envolvidos no tempo de preparação da manufatura, como a separação dos itens que compõem a lista de materiais e a liberação da ordem.

De acordo com os registros de Tenkorang e Helo (2011), as empresas de sucesso devem possuir habilidades que as capacitem para apontar respostas rápidas a mudanças por um custo relativamente baixo. Em especial, as organizações precisam desenvolver os aspectos de responsividade, orientação à demanda e lucratividade através da otimização de suas operações.

É comum encontrar plantas de manufatura operando segundo uma combinação das várias tipologias apresentadas na literatura (ARTIBA e ELMAGHRABY, 1996), sem que haja uma clara distinção entre os vários ambientes e as possíveis classificações de sistemas de manufatura.

"Até mesmo na manufatura discreta as configurações de máquinas individuais e grupos de máquinas agora podem ser sentidas e mudadas quando necessário para fornecer produtos de dimensões uniformes." (GAITHER e FRAZIER, 1999). 
As tecnologias aplicadas em manufatura discreta podem ser bastante úteis, pois aprimoram o controle de máquinas, sistemas de inspeção e outras partes que em conjunto operam para tornar possível o controle da produção, em um contexto complexo em que existem diversos arranjos e combinações entre máquinas e operadores, adaptações de roteiros e operações.

Considerando o fato de que os produtos são produzidos em lotes (flow shop ou job shop), o sistema de produção deve ser configurado de modo que possa atender a demanda da produção das inúmeras possibilidades de variações entre os produtos.

Ao pensar na realidade do controle de materiais, máquinas e recursos humanos presente no trabalho de Liu et al. (2008), há uma oportunidade de se resgatar qual seria o impacto destes controles em manufaturas desenvolvidas para produção em lotes e alto grau de variedade.

Além do mais, deve-se atentar para os problemas de DLSP, Discrete Lot Sizing and Scheduling Problem, e o GLSP-ST, General Lot Sizing Problem - Setup Times, para cálculo e dimensionamento de lotes de produção, combinando o problema de dimensionamento de lotes às decisões de programação da produção como o lot-sizing, scheduling problems ou lotscheduling (LIU et al., 2008).

A manufatura discreta exige um Planejamento de Produção bastante detalhado, contendo o agendamento das Ordens de Produção, consumo de matéria-prima e alocação de recursos de Centros de Trabalho. Neste tipo de manufatura há uma grande diversidade de versões e variações de produtos, o que requer um grande controle sobre os pedidos dos clientes e soluções de engenharia através de pesquisa e desenvolvimento de projetos.

De acordo com a perspectiva de Tubino (1997), os processos discretos envolvem a produção de bens ou serviços que não podem ser isolados, em lotes ou unidades, e detectados em relação aos demais. Podem ser subdivididos em:

Processos repetitivos em massa: produção em grande escala de produtos altamente padronizados. Apresenta uma sequência de produção. Em casos de produtos discretos em indústrias de processo como as químicas, de aviação e papel, a manufatura é classificada como discreta.

Processos repetitivos em lote: produção em lotes de um volume médio de bens ou serviços padronizados, no caso de itens discretos. 
Processos por projeto: atendimento de uma necessidade específica dos clientes, o produto concebido em estreita ligação com o cliente tem uma data determinada para ser concluído. Uma vez concluído, o sistema de produção se volta para um novo projeto.

De acordo com a Figura 11 de Kletti (2007) é possível observar a aplicação direta do sistema sob os sistemas de manufatura discreta e a sua relação com o ERP, além da percepção de integração entre os sistemas ERP e MES.

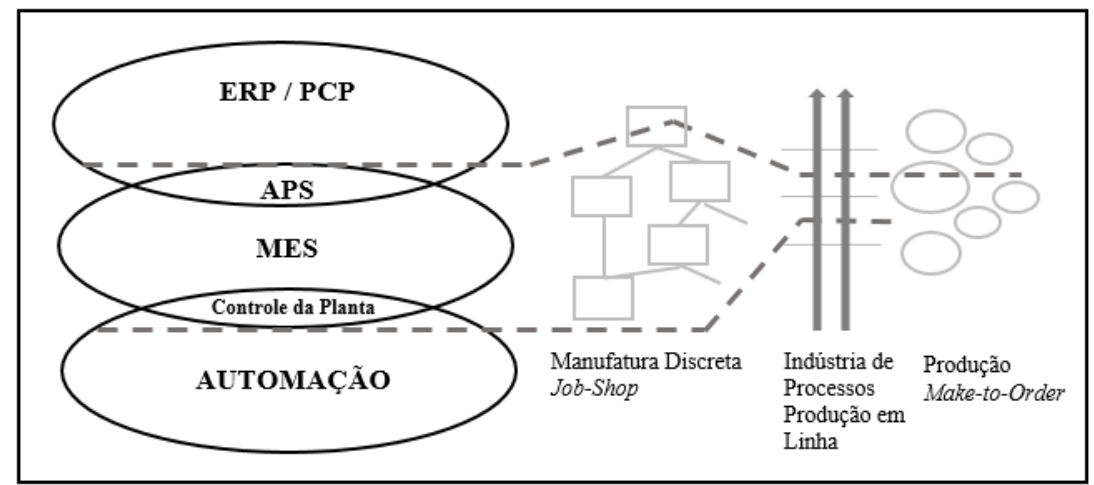

Figura 11 - Funcionalidades do sistema MES para diferentes tipos de manufatura FONTE: KLETTI (2007).

Por esta razão, Wang (2011) identifica que as lacunas existentes entre os estudos de pesquisas e implementações práticas influenciam negativamente as iniciativas da aplicação do MES em ambientes de manufatura, dada as complexidades específicas para este tipo de manufatura.

\subsection{Impacto das integrações de sistemas ERP e MES para a operação}

No entanto, a exploração do tema quando há uma integração entre o sistema ERP e o software MES em indústrias de manufatura discreta tem sido disponibilizada com menor frequência. Por sua vez, na indústria de produção contínua, o monitoramento dos processos produtivos em tempo real é mais usual uma vez que há um intervalo reduzido entre o tempo de detecção da falha e sua correção.

Seguindo as verificações de Martins e Bremer (2002), os sistemas SCADA, por exemplo, surgiram para atender as necessidades das indústrias de processos contínuo no 
monitoramento da produção, mostrando de forma visual o andamento e o status do seu chãode-fábrica.

Há alguns anos, foram adaptados para ambiente de manufatura híbrida ou discreta automatizada e semi-automatizada, e futuramente, serão utilizados em uma escala maior também por esse segmento industrial.

Autores como Gaither e Frazier (1999), acreditam que através da automatização, os custos variáveis poderão tornar-se custos fixos com implementação de novas tecnologias e viceversa, porém com predominância de custos fixos. O único custo variável significativo será o de materiais e gastos gerais, como custos de escritório e funcionários, engenharia, equipamentos, ferramentaria, manutenção, utilidades e softwares. Os custos de mão-de-obra serão considerados como fixos.

No Quadro 2 sugerido, destaca-se a demanda por informações coerentes de orçamento, estoques, custos por dimensões financeiras e investimentos sob uma perspectiva gerencial, o que pode demandar o uso de novas tecnologias capazes de fornecer tais informações.

\section{Quadro 2 - Integração entre as diversas iniciativas}
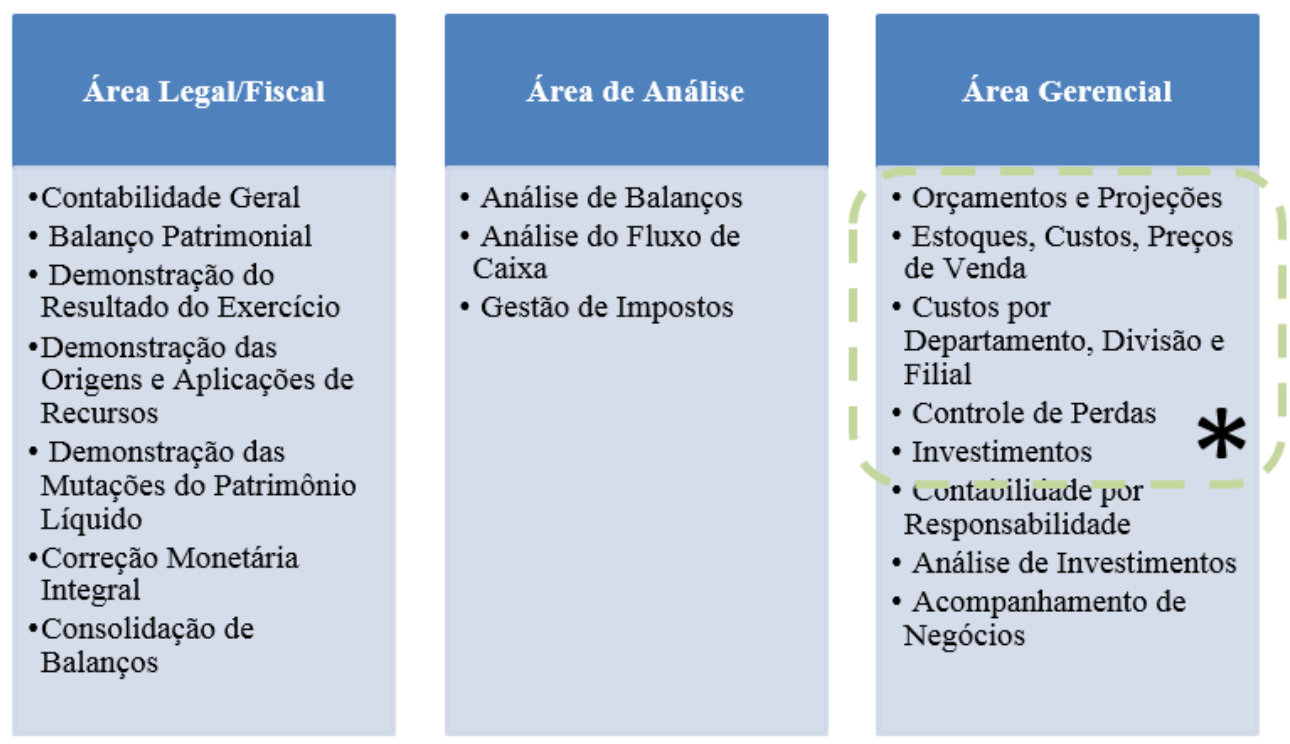

FONTE: Adaptado PADOVEZE, 1998.

Para atender a complexa necessidade de informações sobre o consumo de recursos para elaboração do custeio, o MES compreende doze funcionalidades orientadas ao fornecimento de informações consistentes sobre os recursos humanos, materiais, equipamentos e capital para aumentar a competitividade das empresas (KLETTI, 2007; LIU et al., 2008). 
Dentre elas estão o planejamento detalhado, gerenciamento de recursos humanos, registro e visibilidade dos recursos, gerenciamento de documentos, gerenciamento de materiais e análise de desempenho.

Há também o gerenciamento de mão-de-obra direta, gerenciamento de manutenção, gerenciamento do processo, gerenciamento da qualidade, coleta de dados e registros e por último, rastreabilidade e genealogia do produto (KLETTI, 2007; LIU et al., 2008).

Todas estas apurações podem ser sintetizadas sob o ponto de vista dos autores Bertó e Beulke (2006) que definem a necessidade proposta para um controle mais eficiente dos custos, aplicando o critério de rateio para cada setor da produção.

Assim, pode-se alcançar um controle mais adequado sob o ponto de vista da fabricação de produtos em diferentes quantidades, diversos modelos e fluxos operacionais, intensidade dos trabalhos efetuados em cada etapa, e alocação de custos indiretos.

Conforme a visão de Deuel (1994), o MES e suas integrações podem propiciar um controle integral da produção o que resulta na melhor solução para controlar todas as variáveis da manufatura, contribuindo para o controle de custos, tantos os diretos quanto os indiretos.

A informação gerada pela integração de sistemas de controles tradicionais permite uma maior acurácia no cálculo dos custos diretos, como os custos com estoque e de produção, consumo de matéria-prima e produtos auxiliares para atualização em tempo real da coleta de custos e sua contabilização (DEUEL, 1994; LIU et al., 2008).

Em contrapartida, o MES pode gerar mais subsídios e visibilidade para o cálculo dos custos indiretos, como custos de venda e de qualidade, que representam atualmente a maior parcela dos custos de fabricação (DEUEL, 1994; LIU et al., 2008).

\subsection{Análise do ERP sob a óptica de custos}

Estudo conduzido pela CNI, Confederação Nacional da Indústria, (2013) posiciona que os custos industriais têm se modificado de forma crescente no transcorrer dos últimos anos, entre 2006 e 2012, conforme exposto. Houve um aumento de 5,8\% dos custos industriais em relação ao ano de 2012, sendo ele composto por um aumento de 9,0\% dos custos de produção propriamente ditos. A análise expõe ainda uma tendência acentuada entre os anos de 2009 a 2012.

Tais custos foram influenciados pelos bens intermediários como insumos e matériasprimas, além do gasto com pessoal. Como propõe o estudo, os gastos com pessoal 
desempenham um papel primordial dentro dos custos de produção. Isto significa que as indústrias necessitam de ferramentas para alocar de forma estratégica os recursos humanos.

De forma análoga ocorre com os custos com bens intermediários que acompanham o ritmo de crescimentos dos custos de produção ao longo dos anos. Em menor proporção, mas também em ritmo crescente, aparecem os gastos despendidos com energia. Todavia, em alguns anos esta relação se manteve negativamente proporcional, com maior custo de energia em detrimento dos custos de produção.

Não obstante, é preciso lembrar sobre os fatores que contribuem para este aumento, pois deste modo contribui para que os geradores de custos possam ser identificados, tornando as indústrias mais competitivas no mercado global. Este desempenho poderia ser exibido através de investimentos em novas tecnologias, capacitação de mão-de-obra e aprimoramento de processos.

De acordo com a CNI (2011), outros fatores a serem considerados são: Faturamento; Horas Trabalhadas na Produção; Massa Salarial incluindo todos os benefícios, participações e horas extras; Utilização da capacidade instalada; Custo de Produção, Distribuição e Logística; Custo da informação; Pós-venda; Descarte do produto; Custo ambiental; PD.

As soluções propostas para a resolução dos problemas encontrados na redução de custos através do sistema ERP têm sido amplamente divulgadas na literatura.

Uma necessidade básica para uma contabilidade de custos adequada é a existência de quantificações físicas para todos os valores monetários, as quais podem ser mensuradas mediante o uso de ferramentas como o sistema ERP, por meio de um processo ordenado do uso dos princípios da contabilidade geral para registrar os custos de operação de um negócio (MARTINS, 2003; LAWRENCE, 1977).

Ainda sob a perspectiva de Martins (2003), um diferencial obtido com o sistema ERP é a sistematização criada para o registro de volumes físicos consumidos e fabricados, embora nem sempre exista uma viabilidade econômica para o levantamento de certos dados físicos.

Para tanto, Bruni (2008) argumenta que a rentabilidade, custos e preços planejados para o futuro somente podem ser pensados mediante a análise estratégica da empresa e de seu ambiente competitivo.

Nesta linha, o autor Atkinson et al. (2008) recomenda comparar a visão da Contabilidade Financeira em relação à Contabilidade Geral, para a avaliação gerencial do desempenho dos custos. A primeira prioriza as informações para tomada de decisões, orientadas para o futuro para medição de desempenho operacional e de processo. 
Em contrapartida, a Contabilidade Geral enfatiza o reporte de desempenho passado com finalidades de obrigações legais e características analíticas com alto grau de objetividade.

Dessa forma, através de informações acerca das operações e das vendas, a administração pode empregar os dados contábeis e financeiros para estabelecer os custos de produção e distribuição, além dos custos das outras diversas funções do negócio (ATKINSON et al., 2008; GUTIERREZ et al., 2010).

Para a formação de preço e tomada de decisões, o sistema pode contribuir com a coleta e o agrupamento de informações de análise relevantes, uma vez que o departamento de vendas anseia por dados reais na linha de produção para que possa planejar e readequar os valores comercializados em casos de flutuações na linha de produção (LIU et al., 2008).

No entender de Leone (1989), a primeira fase da contabilidade de custos de uma empresa consiste no trabalho de coleta e seleção de dados internos e externos, quantitativos e monetários que ocorre em subsistemas de apoio, constituídos pelas áreas funcionais e instrumentos de controle da empresa tais como etapas de produção, sistema de controles de materiais, controle de patrimônio e planejamento de produção.

O mesmo autor reforça que outra área conceitual que apresenta certa dificuldade nas organizações refere-se à compreensão e/ou conhecimento dos sistemas e métodos de custos disponíveis, o que pode levá-las a escolhas impróprias ou inadequadas no momento da implementação.

Em uma análise mais focada a área de Contabilidade, segundos outros estudos destes autores, identificou-se que a instalação dos ERP apresentou baixo impacto no gerenciamento contábil em si. Mas, em contraste, o ERP apresentou um impacto positivo como facilitador nas transações do gerenciamento contábil.

Como principais usufrutos, o ERP forneceu informações mais precisas para a tomada de decisão, mas também contribuiu para redução dos níveis de estoque e também dos custos operacionais (SANGSTER et al., 2009).

Tais contribuições podem auxiliar os gestores a compreender melhor a composição dos custos de manufatura conforme o esquema a seguir. Isto é, permitem a atuação direta nos pontos em que pode haver algum tipo de melhoria, como o consumo de materiais e mão-de-obra, ou a formação de custos indiretos.

Outros estudos como os dos autores Sangster et al. (2009), apontam que dentre os principais requisitos para a implementação do ERP, destacam-se as habilidades de manuseio do sistema, habilidades analíticas e em menor grau os fatores técnicos de contabilidade. 
O ERP também demonstrou potencial para reduzir a rotina de trabalho de controllers e contadores através da automatização de vários processos anteriormente conduzidos de forma manual e também pela emissão de relatórios de forma mais autônoma por parte dos gestores sem necessitar a solicitação de emissão para outros colaboradores. Desta forma, maior tempo pode ser direcionado para análise de dados ao invés de sua coleta.

Para Riccio (2001), em seu estudo de caso, a área de Contabilidade utilizava inúmeras informações relevantes referentes aos produtos, matéria-prima, Roteiro de Produção, Ordens de Produção e Compra, entre outras. Em contrapartida, a área de Contabilidade fornecia informações relacionadas a custos de aquisição de peças e matéria-prima, custo de mão-deobra, custos de produção e indiretos. Além do mais, poderia haver uma comparação entre custos totais e unitários, e também entre custos diretos e indiretos, por objeto de custeio.

Na visão de Riccio (2001), grande parte das empresas de pequeno e médio porte ainda carece da implantação de ERP que possuam integração com o módulo contábil, e que seja capaz de gerar indicadores de controle. Muitas empresas adquirem sistemas de diversos fornecedores e os integram aos sistemas desenvolvidos internamente.

Conforme Lira et al. (2012), os módulos de Controladoria nos sistemas ERP consistem nas funcionalidades contábeis gerais tais como, cadastro do Plano de Contas, alocação de custos, faturamento, recebíveis, pagáveis, gerenciamento de contas e ativos.

Vale destacar que segundo os dados da empresa de software DBA (2011), as empresas de manufatura necessitam de sistemas integrados com a Contabilidade e que sejam capazes de calcular o custo do estoque em processo e também alocar os custos indiretos aos produtos.

Para os autores, o uso do ERP influencia os controles de custos no sentido de adicionar valor em sua análise, e também aumentar a acuracidade sobre os custos de manufatura. Fornece o suporte para o controle de custos e promove de uma forma mais sólida o cálculo do custo padrão ou alvo.

Dependendo da complexidade da manufatura, a diferença entre os valores de custo padrão e o custo real pode variar consideravelmente e por isso a necessidade de calcular um custo padrão bastante preciso, projetando metas e orçamentos em um período específico (DBA, 2011; LIU et al., 2008; GUTIERREZ et al., 2010).

Em decorrência do cálculo de custo padrão torna-se possível estudar as suas variações dentro de um determinado período, comparando os resultados obtidos versus os planejados, de forma que a instituição possa identificar possíveis erros na análise dos custos. Em paralelo, os sistemas permitem a visualização de custos por atividade (DBA, 2011; LIU et al., 2008). 
Uma das principais influências sobre a Controladoria seria a eliminação de atividades redundantes e incorporação de novos paradigmas gerenciais. Reduz o tempo necessário para conduzir as operações de planejamento, orçamentos, fechamento contábil, entre outras.

Sob outra visão, os ERP parecem propiciar um aumento qualitativo para os processos de tomadas de decisão, com dados mais organizados, integrados e confiáveis.

Há também uma mudança na estrutura das funções da Controladoria com os processos integrados no sistema ERP, com redução dos custos fixos nos processos contábeis e custos administrativos. O ERP pode contribuir no controle de custos no seguinte sentido:

$\checkmark$ Custo estimado por produto;

$\checkmark$ Custo estimado por família e grupo de materiais;

$\checkmark$ Custos de aquisição;

$\checkmark$ Custos de manufatura;

$\checkmark$ Custo médio de inventário;

$\checkmark$ Alocação por Centro de Custos.

Já nos estudos promovidos por Momoh e Shebab (2010), entende-se que o uso do ERP pode promover mudanças nas funções de custos no sentido de reduzir os custos de uma determinada estrutura de função.

No ponto de vista de Gutierrez et al. (2010), as empresas podem verificar também as exigências legais conciliando-as com a informações gerenciais geradas pelo ERP, em relação ao planejamento e controle sob o custeio da produção, valorização de estoque.

Na mesma linha, os autores Liu et al. (2008) e Giacon (2011), mencionam que o ERP podem ajudar na definição dos direcionadores de custos do ponto de vista estratégico e também no alinhamento entre custos e o alinhamento da utilização da capacidade produtiva.

Os estudos de Lira et al. (2012) revelam que 55\% dos participantes concordam que o ERP atende as necessidades de Controladoria e que 35\% afirmam que o sistema atende de forma parcial. Para 70\%, o ERP permite o uso de novos conceitos para o gerenciamento da Controladoria. Já nos estudos de Giacon (2011), o fator redução de custo quando analisada a instalação de um ERP assumiu um elevado fator de importância dentro dos objetivos desenhados para o PCP, ocupando a segunda posição dentre aqueles mais importantes.

Sendo o ERP uma das tecnologias mais difundidas para a gestão de empresas, foi desenvolvido uma outra tecnologia para suprir a lacuna existente entre o chão-de-fábrica e as informações manipuladas pelo ERP, denominada MES, cuja integração com o ERP será discutida adiante. 


\subsection{Custos operacionais do processo}

Os custos operacionais do processo são divididos entre custos fixos e variáveis. Os custos fixos a serem considerados são os custos com equipamentos, maquinários e mão-deobra. Já os custos variáveis são relativos à eficiência do ciclo de processo e as taxas de produtos defeituosos (DEUEL, 1994).

Através de ações sobre os custos variáveis, é possível reduzir os custos de atividades que não agregam valor, reduzir o tempo de produção e produtos em processo ou Work in Process (WIP).

Ademais, na apuração dos autores a integração poderia fornecer subsídios para a implantação do método de custeio ABC, Activity Based Costing. Os sistemas poderiam contribuir para o mapeamento assíduo das atividades e distingui-las entre si (LIU et al., 2008).

Logo, as organizações teriam a opção de agrupar atividades semelhantes, segmentá-las em centros de trabalho e também agrupar as atividades de acordo com os direcionadores de custos ou cost drivers e também pelos departamentos ou centros de custos de atividades, sendo possível também alocar os custos indiretos a objetos de custos de forma mais apropriada, por meio de apropriações ou critérios de rateios, e posteriormente a distribuição de custos por produtos.

Com as informações mais atualizadas, poderia ser praticado o método de ABM, Activity Based Management, para a gestão da alta gerência, já que seriam disponibilizadas informações decorrentes das principais atividades e os custos atualizados conforme o custeio alvo de cada uma delas para obter uma redução de custos.

Na opinião dos autores Liu et al. (2008), a integração dos sistemas podem proporcionar uma visão de status do controle de custos antes, durante e após a produção, atendendo as normas de acuracidade, confiabilidade e consistência da contabilidade de custos.

Por meio do MES, entende-se que o departamento financeiro pode obter dados rapidamente dos centros de custos e departamentos. Pode analisar também as propriedades financeiras da empresa não apenas sobre o ponto de vista da manufatura, mas também sob a óptica do fluxo de informações e da cadeia de valor com atividades primárias e secundárias (LIU et al., 2008).

Complementando esta visão, a Figura 12 apresenta um resumo de como o MES, junto ao ERP, poderia contribuir para obter o detalhamento da composição de custos e potencialmente, evidenciar identificação de melhorias e reduções. 


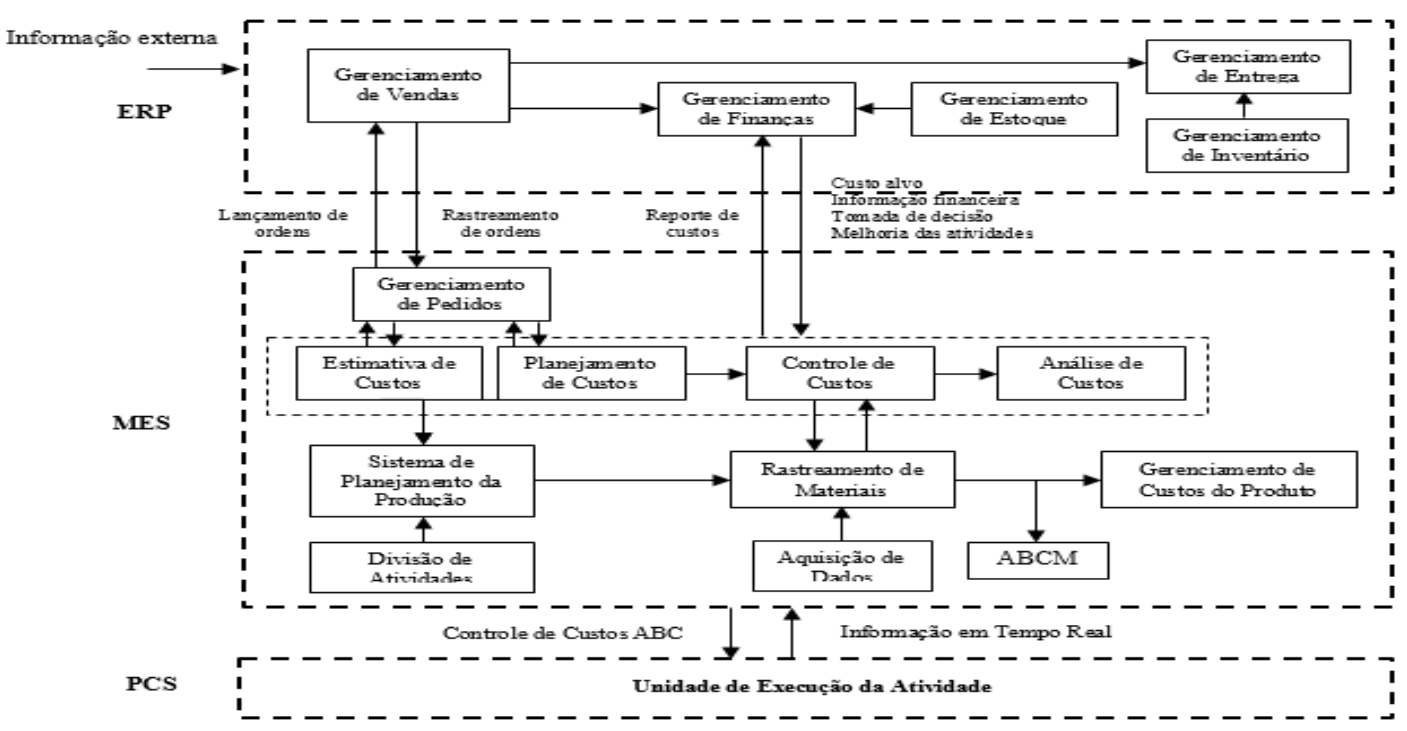

Figura 12 - Framework do sistema de gerenciamento de custos baseados no ERP e MES FONTE: Adaptado de HUANG et al (2004).

A respeito dos custos indiretos, diversos autores como Liu et al. (2008), as informações financeiras das atividades de produção e também de operações relacionadas a logística e movimentação são de suma relevância.

O MES oferece soluções orientadas para o custeio $\mathrm{ABC}$ onde o foco principal consiste na definição das atividades, alocação de custos entre os diversos centros de custos das atividades e a posterior apropriação de custos por produto (LIU et al., 2008).

Em seguida, os autores Liu et al. (2008) verificam que a transferência de vouchers financeiros durante as transações operacionais facilita a troca de dados entre a manufatura e a contabilidade.

Todavia, a análise dos dados passar a ter um perfil mais qualitativo e dinâmico em detrimento do perfil quantitativo e estático que os cenários operacionais são capazes de transmitir.

Essa dinâmica pode contribuir para a identificação de atividades e por consequência a alocação dos custos indiretos de produção, tornando o custeio mais próximo da realidade. Desta forma, medidas podem ser tomadas para a redução de custos, dentro das formulações do $\mathrm{ABC}$ e ABM (LIU et al., 2008).

Para que o método ABC possa ser aplicado através da integração do MES é necessário verificar algumas circunstâncias como a alocação de custos por processos, determinantes e 
direcionadores de custos, alocação de custos médios, alocações de custos posteriores, contabilização de custos e disponibilidade de dados (LIU et al., 2008).

No entender dos autores Kovaleski et al. (2005) existem também os chamados custos de manutenção preventiva e corretiva, compostos pelos custos de material, recursos humanos, interferência na produção e perdas do processo (DEUEL, 1994).

Os custos de material e recursos humanos seriam formados pelos elementos necessários para conduzir as atividades dispostas à manutenção por linha e unidades produzidas. Igualmente, os gestores da área de manutenção devem formular uma estratégia de manutenção dos maquinários da planta e verificar constantemente os seus custos (KOVALESKI et al., 2005; DEUEL, 1994).

O setor de manufatura carece de dados sobre os status das ordens de produção e consumo de material, no sentido de reduzir consumo de materiais e rearranjar equipes de trabalho em caso de imprevistos (LIU et al., 2008), ou seja, tomada de ações imediatas que refletem nos custos dos produtos.

Já o custo de interferência na produção representa o valor perdido em decorrência do tempo de parada do sistema de produção. Logo, os custos de perdas de processo significam os custos relativos a refugos e desperdícios de insumos por consequência das paradas (KOVALESKI et al., 2005).

Ao estudar este tópico, os autores Liu et al. (2008) apreenderam que o problema oriundo planejamento pode estar vinculado a falta de informações dinâmicas, compartilhamento de informações entre as áreas e sistematização, causando uma distorção no controle de custos operacionais em termos de contabilização de custos de produtos, análise e previsões.

Alguns fatores como o longo ciclo para a contabilização de custos, escassez de informações de controle de custos, falta de informações padronizadas e base para precificação, podem acarretar em problemas no cálculo das margens e dos preços de venda e ainda sobre as decisões tomadas (LIU et al., 2008).

Como exemplo pode-se citar a venda de itens que não foram produzidos ainda ou que foram negociados a preços abaixo dos custos de produção, com tempo de entrega não definidos. 
Na opinião de Liu et al. (2008), para realizar um controle dinâmico e contabilização dos custos operacionais conforme o planejamento dos trabalhos de produção é requerido focar na atualização de dados. O sistema de controle de custos seria composto pelas estatísticas de custos, contabilização e análise de custos, controles e emissão de relatórios, por meio de cálculo de taxas e performance (LIU et al., 2008; DEUEL, 1994).

Os autores ressaltam que desta maneira os custos estarão alinhados com as estratégias de qualidade, tecnologia e operações disseminadas internamente, com alto grau de compartilhamento e participação de recursos humanos.

A tecnologia exerceria uma função relevante neste sentido, pois poderia prevenir o uso de inúmeros sistemas desenvolvidos para atender diversas demandas de custos. Tal medida pode ocasionar um desencontro de informações e baixa correlação de dados. (LIU et al., 2008).

Adicionalmente, pode-se estudar a questão dos treinamentos oferecidos aos colaboradores para que possam se adequar aos sistemas e ao preparo da própria cultura organizacional em absorver eventuais mudanças nos processos. Neste sentido, seria necessário verificar o real impacto sobre a redução de custos (GEORGES, 2010; GAMA, 2011).

Segundo Liu et al. (2008), as organizações orientadas para uma cultura de redução de custos são capazes de tomar diversas ações percebidas por seus clientes, sejam elas através de inovação tecnológica, aumento da qualidade ou otimização de estrutura de produto, performance de estoque ou redução do time-to-market (LIU et al., 2008; DEUEL, 1994).

Por meio dos direcionadores de custos é possível obter a um nível estratégico e operacional, informações consistentes das escalas, diversidades técnicas e gestão da qualidade dos produtos (LIU et al., 2008).

Através da construção de interfaces os sistemas ERP captam dados coletados das chamadas Atividades Primárias, integram e validam os dados, e os disponibilizam para as diversas áreas, além de controlar as atividades que viabilizam e complementam as atividades primárias, as quais seriam: Finanças, Recursos Humanos, Contabilidade, Fiscal, Infra, Tecnologia da Informação.

Avaliar as atividades que geram valor e que não geram valor e como a integração MES x ERP pode auxiliar nestas observações, conforme definido pelos autores Horngren et al. (2004).

Segundo os autores Bertó e Beulke (2006), outra perspectiva interessante de ser mensurada são os planejamentos e eventuais despesas tributárias. Confirmando esta concepção, 
os autores Perez et al. (1999) versam a respeito da necessidade de disseminar o custo integrado e coordenado com a contabilidade, de forma que atenda as exigências da legislação tributária.

Além destes pode-se considerar a redução de custos com aluguel a partir da redução de necessidade de espaços físicos maiores já que haverá uma previsão mais acurada do espaço requisitado para armazenar o estoque, seja de matéria-prima, produtos intermediários ou acabados.

Segundo os mesmos autores, atualmente a falta de segurança de custos apurados pode comprometer seriamente os resultados contábeis e levar a administração a adotar decisões que comprometam o futuro da empresa. O aumento da participação de custos indiretos no custeio total da produção, devido ao aumento da automatização pode elevar este descolamento.

No Quadro 3, os autores ressaltam os sistemas de custeio, conforme o a aplicação de manufatura contínua, por processo ou encomenda, principalmente em relação às diferenças de acumulação de custos e cálculo de custos indiretos.

Quadro 3 - Quadro comparativo dos tipos de produção

\begin{tabular}{|c|l|l|}
\hline Sistema de Acumulação de Custos & \multicolumn{1}{|c|}{$\begin{array}{c}\text { Produção Contínua ou Por } \\
\text { Processo }\end{array}$} & \multicolumn{1}{c|}{ Produção por Encomenda } \\
\hline \multirow{2}{*}{ Tipos de Indústrias } & $\begin{array}{l}\text { Cimento, setor químico, têxteis, } \\
\text { vestuários, farmacêuticas, } \\
\text { alimentícias, siderúrgicas, } \\
\text { automobolística e eletroeletrônicos. }\end{array}$ & $\begin{array}{l}\text { Construção naval, máquinas e } \\
\text { equipamentos pesados, consultorias, } \\
\text { construção civil e aeronaves, } \\
\text { transportes especializados. }\end{array}$ \\
\hline \multirow{2}{*}{ Aplicações } & $\begin{array}{l}\nearrow \text { Acumulação por departamento ou } \\
\text { centros de custo. }\end{array}$ & $\begin{array}{l}\nearrow \text { Custeio por Ordem de Produção. } \\
\text { auxiliares são rateados. }\end{array}$ \\
\cline { 2 - 2 } & $\begin{array}{l}\nearrow \text { Custos acumulados por produto ou } \\
\text { lote fabricado e identificáveis ao } \\
\text { longo dos estágios. }\end{array}$ \\
\hline $\begin{array}{l}\text { baseado no custo unitário de cada } \\
\text { departamento. }\end{array}$ & $\begin{array}{l}\nearrow \text { Acumulação de custos diretos e } \\
\text { indiretos, a partir de ordens } \\
\text { encerradas. }\end{array}$ \\
\hline
\end{tabular}

FONTE: Adaptado PEREZ et al, 1999.

A Figura 13 propõe esquematizar os diversos prismas através dos quais os custos de produção podem ser observados. Dentre as perspectivas, pode ser destacado o custo unitário de produto, que eventualmente poderá ser calculado para tomadas de decisão na manufatura. 


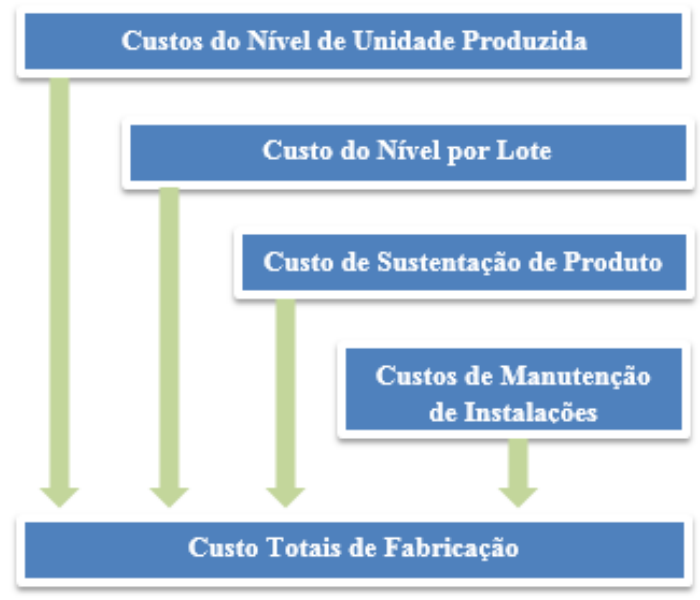

Figura 13 - Hierarquia de custos de produção FONTE: HORNGREN (1997)

Finalmente, outra visão interessante seria comparar os custos de oportunidade ao adotar determinadas decisões em detrimentos de outras. Conforme explicita os autores Horngren et al (2004), este custo é representado pela contribuição de renda que é perdida, quando não se utiliza um recurso limitado na sua segunda melhor alternativa de uso.

\subsection{Classificação de tópicos tratados pelo MES}

As propriedades alegadas pelos autores Adler et al. (1995), Deuel (1994), Vanderlei (2010), Berti (2011), assim como MESA (1997) em relação ao MES foram agrupadas segundo algumas perspectivas de propriedades do MES que demandam uma maior atenção e que foram organizadas em diversos grupos de análise, como o gerenciamento de produtos e matéria-prima, gerenciamento de equipamentos e mão-de-obra, gerenciamento do planejamento e agendamento dos jobs de produção, gerenciamento da qualidade e operações, e finalmente, o gerenciamento de conformidades regulamentórias.

O Quadro 4 a seguir apresenta uma síntese dos autores e também reflexões do próprio autor em relação à classificação dos tópicos tratados pelo MES, principalmente com base no trabalho seminal do autor Deuel (1994). Procura elucidar sobre as particularidades encontradas no MES, discutindo não somente os impactos benéficos sobre a visão real da manufatura como também os negativos e suas consequências. 
É preciso ir além e verificar as intersecções entre os diversos sistemas e refletir sobre até que ponto as integrações são capazes de ultrapassar os limites internos impostos pelas dificuldades operacionais e do investimento realizado na aquisição dos sistemas.

Quadro 4 - Classificação de tópicos tratados pelo MES

\begin{tabular}{|c|c|c|c|}
\hline MATERIAIS & $\begin{array}{c}\text { RECURSOS - } \\
\text { EQUIPAMENTOS }\end{array}$ & $\begin{array}{c}\text { RECURSOS - MÃO- } \\
\text { DE-OBRA }\end{array}$ & JOBS \\
\hline $\begin{array}{l}\text { Gerenciamento de } \\
\text { inventário, estoque WIP } \\
\text { e nível de estoque } \\
\text { Gerenciamento de Listas } \\
\text { de Materiais ou BOM, } \\
\text { Bill of Material, e } \\
\text { Design de Engenharia } \\
\text { Cálculo de necessidades, } \\
\text { inspeção de materiais e } \\
\text { status por lote } \\
\text { Rastreamento de } \\
\text { materiais indiretos, vida } \\
\text { útil, materiais adicionais } \\
\text { e embalagem } \\
\text { Redução de scrap, } \\
\text { retrabalho, taxas de } \\
\text { reciclagem, movimentos } \\
\text { desnecessários de } \\
\text { materiais e energia } \\
\text { Cálculo de taxas e } \\
\text { estatísticas de consumo }\end{array}$ & $\begin{array}{l}\text { Gerenciar os recursos de } \\
\text { equipamentos que possuem } \\
\text { alta representatividade dos } \\
\text { custos de fabricação do } \\
\text { produto } \\
\text { Maximizar proativamente a } \\
\text { Taxa de Utilização efetiva } \\
\text { de equipamento, aliada ao } \\
\text { agendamento efetivo } \\
\text { Manutenção e ações } \\
\text { preventivas para evitar } \\
\text { quebras. Redução de } \\
\text { downtimes } \\
\text { Balancear o uso da máquina } \\
\text { e manutenção. Alocação } \\
\text { eficiente de equipamentos } \\
\text { Cálculo de Taxa de } \\
\text { Capacidade/Eficiência, } \\
\text { através de dados e análise de } \\
\text { tendências, reduzindo os } \\
\text { tempos ociosos } \\
\text { Analisar velocidade e } \\
\text { consumo de energia. } \\
\text { Otimização de produtividade } \\
\text { e qualidade } \\
\text { Gravação de registros de } \\
\text { quebras de equipamentos } \\
\text { para execução de } \\
\text { manutenção } \\
\text { preventiva/preditiva } \\
\text { produtos dumos de produção } \\
\text { Agendamento e } \\
\text { planejamentos efetivos } \\
\text { conforme a capacidade de } \\
\text { cada máquina, evitando a } \\
\text { formação de gargalos } \\
\text { Minimização de setups e } \\
\text { ciclos de trocas e ajustes de } \\
\text { máquinas }\end{array}$ & 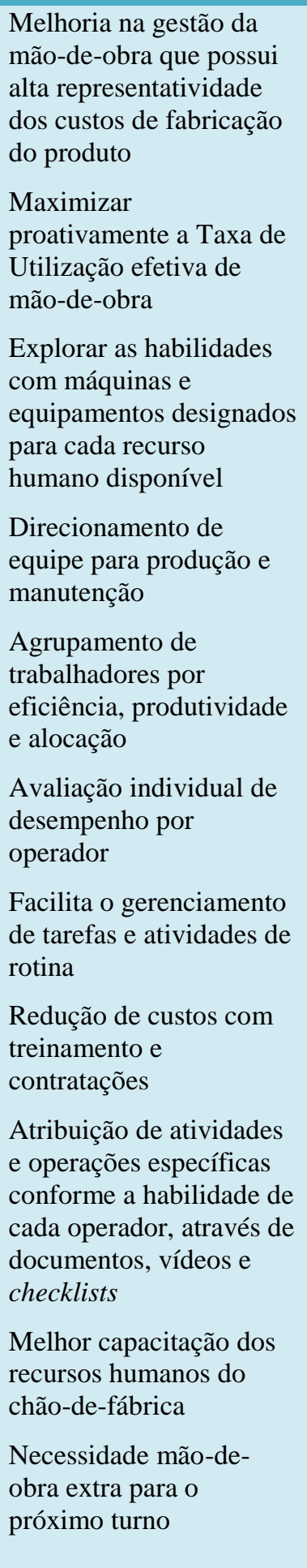 & $\begin{array}{l}\text { Aceitação do pedido } \\
\text { de produção para } \\
\text { início do trabalho, } \\
\text { através da integração } \\
\text { com o sistema ERP } \\
\text { Atualização do } \\
\text { Planejamento da } \\
\text { Produção, conforme } \\
\text { as ações reais no } \\
\text { chão-de-fábrica } \\
\text { Atualização de dados } \\
\text { conforme a alteração } \\
\text { de turnos, devido às } \\
\text { mudanças e } \\
\text { imprevistos ocorridos } \\
\text { ao longo dos turnos, } \\
\text { como a falta de } \\
\text { qualidade, restrição } \\
\text { de mão-de-obra e } \\
\text { quebra de } \\
\text { equipamentos. } \\
\text { Redução do tempo de } \\
\text { ciclo, espera e } \\
\text { formação de filas } \\
\text { Rastreamento e } \\
\text { posicionamento dos } \\
\text { trabalhos de } \\
\text { produção, fornecendo } \\
\text { aos clientes, gerentes } \\
\text { e usuários um } \\
\text { posicionamento } \\
\text { preciso das ordens e o } \\
\text { status de cada uma } \\
\text { delas } \\
\text { Sugestão de } \\
\text { alternativas para } \\
\text { alocação de recursos } \\
\text { em caso de } \\
\text { contratempos } \\
\text { O registro do } \\
\text { eletrônico permite a } \\
\text { comparação de } \\
\text { desempenho }\end{array}$ \\
\hline
\end{tabular}




\begin{tabular}{|c|c|c|c|}
\hline $\begin{array}{l}\text { Redução do excesso de } \\
\text { inventário, através de } \\
\text { práticas MTO, Make-to- } \\
\text { Order, em detrimento do } \\
\text { MTS, Make-to-Stock } \\
\text { Minimização de } \\
\text { produtos defeituosos } \\
\text { Faltas frequentes e } \\
\text { localização de materiais, } \\
\text { acarretando a parada do } \\
\text { processo fabril } \\
\text { Constantes } \\
\text { cancelamentos de ordem } \\
\text { de compra e alto custo } \\
\text { de estoque } \\
\text { Materiais de reposição e } \\
\text { suporte }\end{array}$ & $\begin{array}{l}\text { momentos antes do } \\
\text { despacho } \\
\text { Controle por estação de } \\
\text { trabalho em horas e números } \\
\text { por turno } \\
\text { Consumo atual versus } \\
\text { estoque existente } \\
\text { Substituição de } \\
\text { equipamentos }\end{array}$ & & $\begin{array}{l}\text { A alocação de novos } \\
\text { pedidos pode ser } \\
\text { avaliada rapidamente } \\
\text { pelos planejadores de } \\
\text { produção } \\
\text { Distribuição de jobs } \\
\text { por máquina e } \\
\text { eliminação dos } \\
\text { gargalos } \\
\text { Formação de Planos } \\
\text { de Contingência } \\
\text { Percentual de } \\
\text { utilização de ativos } \\
\text { mensal, semestral, } \\
\text { anual }\end{array}$ \\
\hline QUALIDADE & OPERAÇÕES & COMPLIANCE & $\begin{array}{l}\text { INTEGRAÇÃO } \\
\text { CONTROLE DE } \\
\text { DISTRIBUIÇÃO }\end{array}$ \\
\hline $\begin{array}{l}\text { Execução de testes e } \\
\text { divulgação de resultados } \\
\text { para vários usuários } \\
\text { simultaneamente } \\
\text { Armazenamento de } \\
\text { histórico para consulta e } \\
\text { alteração de } \\
\text { especificações } \\
\text { SQC Statistic Quality } \\
\text { Control e SPC Statistical } \\
\text { Process Control } \\
\text { Correlação entre } \\
\text { experimentos e amostras } \\
\text { para tomada de decisão } \\
\text { Garantia de } \\
\text { cumprimento de normas } \\
\text { por parte dos operadores }\end{array}$ & $\begin{array}{l}\text { Controle, incorporação dos } \\
\text { procedimentos de processos } \\
\text { e especificações para cada } \\
\text { operação, através de dados } \\
\text { capturados eletronicamente } \\
\text { Definição para processos } \\
\text { discretos semi-automáticos } \\
\text { ou automáticos para } \\
\text { manuseio de materiais, } \\
\text { processamento e inspeção } \\
\text { Etapas para execução de um } \\
\text { trabalho de produção, no } \\
\text { intuito de reduzir a } \\
\text { variabilidade das operações } \\
\text { Instruções eletrônicas de } \\
\text { trabalho e documentação } \\
\text { técnica sobre as operações } \\
\text { Divisão de operações de } \\
\text { start-up, intermediárias, e } \\
\text { desligamento em ambientes } \\
\text { de produção contínua, } \\
\text { híbrida ou por lote } \\
\text { Menor tempo entre o pedido } \\
\text { e a entrega do produto ou } \\
\text { lead-time } \\
\text { Sequenciamento de } \\
\text { atividade e produção } \\
\text { Aumento do controle do } \\
\text { produto através de ações } \\
\text { proativas em relação aos } \\
\text { desvios de especificações } \\
\text { Falta de espaço para o } \\
\text { armazenamento e atrasos }\end{array}$ & $\begin{array}{l}\text { Atendimento as normas } \\
\text { estabelecidas pela } \\
\text { OSHA, EPA, FDA, ISO } \\
9000 \text { e das demandas de } \\
\text { agências reguladoras } \\
\text { através de soluções de } \\
\text { gerenciamento de } \\
\text { segurança } \\
\text { Atualização de dados e } \\
\text { registro de histórico para } \\
\text { consultas no longo e } \\
\text { curto prazo e } \\
\text { arquivamento de } \\
\text { documentação do } \\
\text { produto } \\
\text { Processos de } \\
\text { documentação, } \\
\text { procedimentos de } \\
\text { produção e geração de } \\
\text { evidências } \\
\text { Revisão, análise, } \\
\text { aprovação e auditoria dos } \\
\text { documentos } \\
\text { Registro de treinamentos, } \\
\text { qualificações dos } \\
\text { operadores, certificações, } \\
\text { durante ações em } \\
\text { condições normais ou } \\
\text { anormais } \\
\text { Desenvolvimento de } \\
\text { novas estratégias de } \\
\text { compliance ao longo do } \\
\text { tempo a partir de } \\
\text { observações reais e }\end{array}$ & $\begin{array}{l}\text { Necessidade dos } \\
\text { controles dos custos } \\
\text { diretos, como material } \\
\text { e mão-de-obra } \\
\text { As decisões são } \\
\text { tomadas com base em } \\
\text { atividades em um } \\
\text { curto espaço de } \\
\text { tempo, já que os } \\
\text { gestores não podem } \\
\text { aguardar um longo } \\
\text { período para receber } \\
\text { as informações e a } \\
\text { partir de então tomar } \\
\text { as decisões } \\
\text { Por esta razão, os } \\
\text { pequenos desvios de } \\
\text { planejamento, } \\
\text { quantidade de } \\
\text { inventário e custos } \\
\text { devem ser reportados } \\
\text { e devem constar no } \\
\text { MES } \\
\text { O MES propicia } \\
\text { ações proativas para a } \\
\text { tomada de decisões } \\
\text { antes que os erros } \\
\text { ocorram e por isso é } \\
\text { denominado um early } \\
\text { warning system } \\
\text { Redução ou } \\
\text { eliminação do tempo } \\
\text { de entrada dos dados }\end{array}$ \\
\hline
\end{tabular}




\begin{tabular}{|c|c|c|c|}
\hline $\begin{array}{l}\text { produto em relação a } \\
\text { novos e futuros } \\
\text { desenvolvimentos } \\
\text { Baixa rotatividade de } \\
\text { estoque e grande número } \\
\text { de compras em } \\
\text { emergência }\end{array}$ & $\begin{array}{l}\text { frequentes na entrega de } \\
\text { materiais } \\
\text { Grande variação no capital } \\
\text { de giro aplicado nos } \\
\text { estoques de materiais } \\
\text { Desequilíbrio entre as } \\
\text { atividades da produção e } \\
\text { sequenciamento de } \\
\text { atividades } \\
\text { Oferecer serviços associados } \\
\text { ao produto } \\
\text { Integração vertical e opções } \\
\text { do tipo comprar ou fazer } \\
\text { Alterações de layout } \\
\text { desnecessárias } \\
\text { Checagem de processos } \\
\text { repetitivos ou inadequados e } \\
\text { superprodução } \\
\text { Eliminação ou redução de } \\
\text { controles em papel }\end{array}$ & $\begin{array}{l}\text { programas de prevenção } \\
\text { e estimativa de } \\
\text { ocorrências } \\
\text { Atendimento de } \\
\text { requisitos de agências } \\
\text { regulamentários dos } \\
\text { clientes e fornecedores }\end{array}$ & $\begin{array}{l}\text { e papéis utilizados na } \\
\text { operação }\end{array}$ \\
\hline
\end{tabular}

FONTE: Adaptado ADLER et al, 1995; BERTI, 2011; DEUEL, 1994; GAMA, 2011; GRIEVES, 2006; KLETTI, 2007; KOVALESKI et al, 2005; LIU et al, 2008; MESA, 1997; VANDERLEI, 2010). 


\section{ELABORAÇÃO DE PROPOSIÇÕES}

A partir da revisão bibliográfica foram elaboradas as proposições deste estudo que são detalhadas a seguir.

A finalidade das proposições é verificar como ocorreu o processo de implementação do sistema MES, proveitos e dificuldades encontradas no decorrer dos anos, além de compreender quais os fatores considerados relevantes para a redução de custos, comparando o grau de importância que cada fator ocupa em detrimentos de outros fatores.

Tais proposições serão validadas de forma exploratória, com o objetivo de discuti-las e aprimorá-las em um primeiro momento. Em estudos futuros pode-se visar a uma abordagem quantitativa no sentido de comprovar as proposições utilizadas para a construção de um modelo.

Diante do exposto pelas fundamentações teóricas foram elaboradas 02 proposições a serem exploradas ao longo do questionário desenvolvido nesta pesquisa, no sentido de aprofundar sobre a estruturação dos sistemas para permitir uma melhor gestão estratégica de redução de custos por meio da gestão de scraps, refugos e controle da qualidade. As proposições são apresentadas e discutidas a seguir.

A elaboração das proposições remete-se a algumas argumentações encontradas na literatura em respeito ao MES, tais como:

P1: A integração entre os sistemas ERP e MES em manufaturas discretas pode contribuir para a redução de custos, quando:

a) Existe uma maior confiabilidade no controle de estoque a qual resulta em uma redução de desperdícios com matéria-prima e menor lead-time;

Através da coleta de dados do chão-de-fábrica em tempo real, através de dispositivos eletrônicos é possível obter informações bastante precisas em termos de consumo de estoque (GIACON e MESQUITA, 2011; DEUEL, 1994). 
A informação gerada pela integração de sistemas permite uma maior acurácia no controle dos custos com estoque e de produção, consumo de matéria-prima e produtos auxiliares para atualização dos custos e sua contabilização (DEUEL, 1994; LIU et al., 2008).

As organizações orientadas para uma cultura de redução de custos são capazes de identificar ações no sentido de aumentar a performance do estoque ou reduzir o seu time-tomarket (LIU et al., 2008; DEUEL, 1994).

Por meio de um controle mais detalhado do inventário, do estoque em processo WIP, produtos acabados em estoque e do cálculo do nível do estoque, torna-se viável verificar uma eventual baixa rotatividade de estoque e uma grande variação no capital de giro aplicado nos estoques de materiais. Assim, verificando o estoque parado, pode-se estudar métodos para reduzir o lead-time e aumentar o giro do estoque (ADLER et al., 1995; BERTI, 2011; DEUEL, 1994; KOVALESKI et al., 2005; LIU et al., 2008; MESA, 1997; VANDERLEI, 2010).

b) Existe uma alocação adequada de recursos, redução do setup e tempo de parada de máquinas, as quais resultam em um uso mais eficiente da capacidade das máquinas por meio da otimização e flexibilidade da manufatura;

O MES pode ser útil para indicar a alocação real dos recursos para os respectivos Centros de Trabalho (LIU et al., 2008). Assim, através de ações adequadas de alocação de recursos e sugestão de alternativas para alocação de recursos em caso de contratempos (ADLER et al., 1995; BERTI, 2011; DEUEL, 1994; KOVALESKI et al., 2005; LIU et al., 2008; MESA, 1997; VANDERLEI, 2010) pode-se obter um uso mais adequado da capacidade das máquinas.

O MES também pode destacar os tempos consumidos em setup de máquinas, tempos de espera e movimentação (GAMA, 2011; BERTI, 2011), facilitando a coleta de dados para decisões de aumento da capacidade das máquinas, minimização de setups e ciclos de trocas e ajustes de máquinas (ADLER et al., 1995; BERTI, 2011; DEUEL, 1994; KOVALESKI et al., 2005; LIU et al., 2008; MESA, 1997; VANDERLEI, 2010).

Desta forma, aumenta-se o controle sobre controles estatísticos, rastreabilidade, controle de paradas (GAMA, 2011; GRIEVES, 2006). Além disso, o MES pode oferecer acesso aos relatórios de produção e detalhamento via drill-down, segundo o equipamento, produtos parados na linha de produção e tempo de parada ou identificação de micro-paradas, além de 
emitir sinais em caso de baixa eficiência ou paradas do equipamento (FERRAZI, 2012; STANO, 2011; DEUEL, 1994).

Se tomadas as providências, o MES pode ajudar a identificar os custos de perdas de processo, com refugos e desperdícios de insumos por consequência das paradas (KOVALESKI et al., 2005), auxiliando no cálculo da taxa de capacidade/eficiência, com agendamento e planejamentos efetivos conforme a capacidade de cada máquina, evitando a formação de gargalos (ADLER et al., 1995; BERTI, 2011; DEUEL, 1994; KOVALESKI et al., 2005; LIU et al., 2008; MESA, 1997; VANDERLEI, 2010).

\section{c) Por meio do apontamento real e identificação de problemas decorrentes de programação, existe um melhor planejamento e gerenciamento dos jobs no chão- de-fábrica;}

De posse dos dados capturados em tempo real, o MES pode atualizar a programação detalhada da produção, organizando os recursos disponíveis para a execução do trabalho, o gerenciamento do planejamento e agendamento dos jobs de produção (DEUEL, 1994; BERTI, 2011) e verificando os impactos de eventuais mudanças no ambiente produtivo em termos de programação (ROLÓN e MARTINEZ, 2012).

O MES estaria preparado para indicar uma programação detalhada de atividades, responder aos eventos incertos e aleatórios e também adaptar planejamentos elaborados a determinadas circunstâncias, tais como falta de material e quebra de máquinas (GAMA, 2011; BERTI, 2011). As informações são transmitidas para a gestão e liberação da produção, convertidas em instruções de trabalho (JUNQUEIRA, 2003).

Dentre as principais informações transportadas do MES para o ERP, seriam a respeito de jobs concluídos e performance de operação real (GIACON e MESQUITA, 2011; DEUEL, 1994).

As principais atividades que compreendem a execução e o controle no chão-de-fábrica são a liberação e planejamento das ordens de produção, distribuição de jobs por máquina (ADLER et al., 1995; BERTI, 2011; DEUEL, 1994; KOVALESKI et al., 2005; LIU et al., 2008; MESA, 1997; VANDERLEI, 2010), o sequenciamento das operações e o apontamento da produção, traduzindo estes dados em ações detalhadas e executáveis com propósitos de 
verificação e rastreamento das ordens de produção (FERNANDES, 2010; ROLÓN e MARTINEZ, 2012).

As informações de controle extraídas do chão-de-fábrica são capazes de criar um banco de dados no sistema MES (STANO et al., 2011), cujos apontamentos tinham a operação bastante dificultada pela entrada manual e em planilhas (VANDERLEI, 2010), o que pode resultar em erros de input, informações inconsistentes e divergentes da realidade (FERRAZI, 2012).

P2: A redução de custos pode ocorrer em decorrência das adaptações e reestruturações de processos frente à adoção do MES

A proposição P2 está pautada na sintetização de toda a revisão bibliográfica, e pretende verificar se a redução de custos advém das ações tomadas para mudança de processos, de forma a atender aos requisitos de controle do MES.

Visto que estudos evidenciam que muitas empresas são avessas a mudança, que refletem muitas vezes as percepções e a própria cultura disseminada pelos proprietários ou gestores das empresas, tal fato pode restringir o universo de medidas que poderiam ser tomadas para melhorias ou implantação de novas tecnologias (SNIDER et al., 2009; DEUEL, 1994), podendo-se averiguar também a questão ao preparo da própria cultura organizacional em absorver eventuais mudanças nos processos (GEORGES, 2010; GAMA, 2011). 


\section{METODOLOGIA}

\subsection{Descrição da Metodologia}

O estudo desenvolvido tem como principal conteúdo abordar sobre melhorias obtidas no controle de custos, através da integração dos sistemas ERP e os chamados softwares de MES.

Após identificar os construtos e estabelecer as definições operacionais do estudo, por intermédio da aplicação de um estudo de múltiplos casos, foram captados dados das indústrias de manufatura discreta para que pudessem ser debatidas as opiniões de diversos gestores e verificado se as proposições levantadas no estudo são validadas.

As principais proposições que o estudo pretende verificar é que de fato os altos investimentos em desenvolvimento e implantação de sistemas em indústrias são favoráveis no sentido de proporcionar uma redução de custos, e por este motivo os investimentos em tecnologia devem aumentar.

Inicialmente foram revisadas bibliografias relevantes ao tema de pesquisa, incluindo livros, estudos de periódicos e consulta a base de dados relacionada ao tema de pesquisa, assim como uma pesquisa detalhada sobre tecnologias vigentes no mercado.

Esperava-se que ao final do estudo, fosse possível verificar as melhorias obtidas sob a ótica da redução de custos, com o sistema MES, e também uma possível integração com o ERP.

Em especial, foram avaliadas as principais métricas utilizadas pelos gestores e como as integrações podem contribuir para o fornecimento de informações mais precisas e adequadas para não apenas mensurar os custos de produção, mas também oferecer recursos para a redução de custos.

A justificativa para a escolha da metodologia qualitativa está baseada no teor exploratório que a pesquisa se propõe a estudar. Isto é, procura apenas verificar a aplicação de integração de ERP e MES, e como suas práticas entre manufaturas de diferentes perfis podem contribuir para reduzir custos, entretanto, não busca comprovar ou generalizar nenhum modelo existente entre as diversas empresas de manufatura. 
Trata-se de uma metodologia de pesquisa que procura definir um processo de investigação de caráter exploratório a partir do objetivo delimitado para uma determinada pesquisa, evidenciando a sua natureza e proposta de entrega.

Esta fase foi concebida mediante aplicações de entrevistas de abordagem qualitativa segundo o método de pesquisa de estudo múltiplo de casos (YIN, 2005; VOSS et al., 2002) como uma estratégia de pesquisa (COOPER e SCHINDLER, 2003). Tal estratégia seria indicada para estudos cujos temas possuam um caráter emergente (VOSS et al., 2002).

Desta forma, procurou-se identificar os principais problemas encontrados pela organização, por meio de questionários em que estão relacionadas diversas questões selecionadas conforme a atribuição de pesos de importância.

Gil (1996) esclarece que o estudo de caso é concebido mediante uma análise profunda de um ou mais objetos permitindo o seu conhecimento detalhado. Os estudos de caso procuram esclarecimentos a respeito do motivo pelo qual um fenômeno, uma decisão ou um conjunto de decisões ocorrem, a forma como foram implementadas e caracteriza os resultados alcançados (YIN, 2005).

Através de situações específicas é possível absorver uma compreensão da dinâmica sob a perspectiva de características próprias de cada local de estudo (EISENHARDT, 1989; VOSS et al., 2002).

Através da adoção de estudos de casos múltiplos pretende-se um maior grau de generalização dos resultados obtidos, em detrimento de uma obtenção menor em no que tange a profundidade tratada em cada situação (YIN, 2005; SOUZA, 2005). Em adição, o estudo de casos múltiplos permite um uma maior validade e reduz a probabilidade de ocorrências viesadas (VOSS, 2009; YIN, 2005).

É preciso lembrar que para Voss et al. (2002) se o objetivo da pesquisa corresponder a uma maior generalização da análise, o estudo de caso múltiplo seria bastante indicado ao oferecer uma maior gama de opções tratadas em menor profundidade.

Segundo Bagozzi (1984), a validação do constructo é uma fase muito importante da metodologia de pesquisa, pois exerce a função de verificar se as medidas operacionalizadas estão de fato medindo os conceitos propostos pela teoria, a qual está sendo difundida no estudo. Portanto, é necessário existir um relacionamento semântico e sintático entre os significados teóricos e operacionais do conceito. 
Pode-se afirmar que para Popper (1959), de um ponto de vista epistemológico, o conceito de testes é uma propriedade essencial, que deve estar totalmente integrada a teorias propostas, caso seja desejável lhes atribuir algum significado.

O estudo possui caráter exploratório e foi concebido mediante aplicações de entrevistas de abordagem qualitativa segundo o método de pesquisa de estudo múltiplo de casos de forma a evidenciar os principais problemas encontrados pela organização, por meio de questionários semi-estruturados em que estavam relacionadas diversas questões selecionadas conforme a atribuição de pesos de importância.

Neste projeto foram realizados os estudos de casos em 03 empresas, sendo que o intervalo sugerido por Eisenhard (1989) compreende de 04 a 10 casos.

Neste projeto, o uso da pesquisa exploratória foi justificado pela razão de que procura explorar algumas características do tema já encontrado na literatura e para a formulação de outras hipóteses e buscar outros conhecimentos da área de pesquisa (YIN, 2005, EISENHARDT, 1989).

Em sua obra, Churchill (1979) destaca a necessidade da absorção do conhecimento presente na literatura, e a habilidade e esforços requisitados para transpor este conhecimento e traduzi-lo em medidas palpáveis dentro da pesquisa. Tull e Hawkins (1993) complementam com a ideia de definições operacionais para decifrar as atividades necessárias para atribuir valor as teorias conceituais e modelos.

Em contrapartida, Menon (1992), teoriza sobre as dificuldades encontradas no processo de utilização de conhecimento das firmas, por conta de sua complexidade e dos desafios em conceituar e medir os constructos em uma pesquisa.

\subsection{Estratégia para Coleta de Dados}

A coleta de dados teve início no primeiro quadrimestre de 2014, entre gestores que atuem em unidades de manufatura por meio de entrevistas semi-estruturadas e observações diretas.

A lógica básica da metodologia foi identificar os principais aspectos e tópicos relacionados ao controle de custos, propor tabelas de estudos, formular proposições e comparar 
com as respostas obtidas em campo através de cruzamento de dados, confirmando ou não as proposições montadas através de preceitos teóricos.

Após tentativas de contato para participação da pesquisa, foram selecionadas 03 (três) empresas de manufatura discreta que utilizam o MES, através de interações por $e$-mail. Após um contato inicial, foram enviados os documentos de apresentação da pesquisa e os termos de confidencialidade. Uma vez aprovados pelos gestores, foram agendadas as visitas para apresentação da pesquisa, e posteriormente reuniões para coleta de dados.

Os meios utilizados para transferência de informações e conhecimento foram entrevistas diretas com preenchimento do questionário pelos participantes e transcrição de trechos pelo pesquisador, totalizadas em 03 questionários aplicados entre os gestores de produção, tecnologia e contabilidade entre 03 empresas distintas, com 01 questionário atribuído por cargo.

A coleta foi feita através de questionários semi-estruturados contendo perguntas referentes ao tema, correios eletrônicos, pesquisas na nos sites dos fornecedores e também leituras de portfolios desenvolvidos pelas organizações para a devida coleta de dados secundários. Também foram coletados os depoimentos dos entrevistados.

Além disso, foram exibidos dois exemplos de indústrias para verificar o contexto em que a tecnologia MES foi aplicada.

A partir do referencial teórico foram elaboradas perguntas que compõem o questionário da pesquisa como pilar para a obtenção dos dados. A pesquisa focou em entrevistas realizadas em empresas de manufatura discreta dentro do estado de São Paulo.

Como meio de coleta de dados foram propostas as entrevistas diretas com os gestores das áreas de manufatura e custos que puderam contribuir com percepções sobre o uso de sistemas dentro da manufatura, permeando principalmente os motivos que levaram à adoção do MES e como o processo de aplicação do sistema foi desencadeado ao longo dos anos, levantando benefícios ou eventuais dificuldades encontradas.

A amostra convidada a responder a entrevista foi composta basicamente de profissionais dentre os quais, Gerentes e Supervisores que atuam nos departamentos de PCP (Planejamento e Controle da Produção), Gestão da Tecnologia, Automação Industrial ou Contabilidade de Custos. Foi imprescindível que os profissionais possuíssem mais de 02 (dois) anos de atuação na empresa para que estivessem aptos a responder de forma adequada os questionários. 
Foi entregue um termo de Consentimento Livre e Esclarecido aos participantes da pesquisa informando que será mantido absoluto sigilo quanto à sua identidade. Sendo que a participação é totalmente voluntária, podendo ser cancelada a qualquer momento, não havendo prejuízo ou benefício no desenvolvimento pessoal e profissional na instituição.

O modelo de questionário semi-estruturado pode ser verificado na seção do Apêndice 2 - MODELO DE QUESTIONÁRIO SEMI-ESTRUTURADO, deste trabalho. A distribuição das questões foi feita conforme demonstrado na Figura 14:

\section{Distribuição de questões}

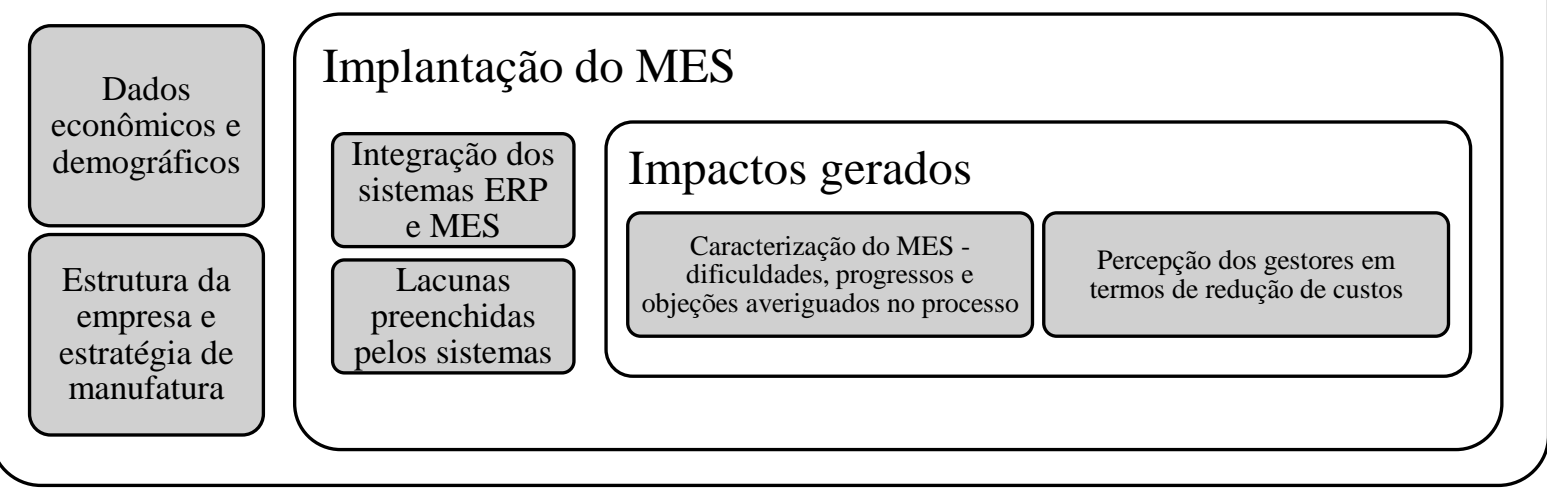

Figura 14 - Variáveis do processo de fabricação

FONTE: Figura elaborada pelo autor da obra.

\subsection{Análise dos Dados - Métodos de análise de resultados}

Após obter os dados, estes foram transcritos para que pudessem ser tabulados e dado início a análise de dados. Todos os dados obtidos foram previamente organizados para facilitar a análise de resultados.

O principal foco deste método seria coletar dados de gestores das áreas de operações e controladoria para checar dois aspectos relevantes do objetivo proposto pela dissertação.

O primeiro deles refere-se a compreender melhor a percepção dos gestores de indústrias quanto aos proveitos gerados pela integração dos sistemas ERP e MES:

O primeiro ponto a ser avaliado é se na percepção destes entrevistados, a Redução de custos teria um desempenho melhor ou não no sentido de controlar as suas diversas variáveis, agrupadas em diferentes constructos. 
Neste aspecto, o objeto principal seria o desempenho na redução de custos e as variáveis determinadas para cada perspectiva que se deseja verificar, como por exemplo, os indicadores de Custos Operacionais, Custos com Mão-de-Obra, Padronização de Custos, entre outras.

Para o segundo ponto espera-se investigar em qual grau cada variável poderia explicar a melhoria de Redução de custos.

Outro aspecto oportuno que será destacado nas análises de dados será compreender se a área de atuação, tempo de atuação, tipos de indústrias, dos entrevistados estão associados a respostas para determinadas variáveis e também se estas áreas estão intimamente relacionadas as tendências de posicionamento de cada gestor em relação aos resultados globais gerados em detrimento da integração dos sistemas ERP e o MES.

Segundo Hair et al. (2010), alguns erros podem ser originados devido à estrutura do questionário, escalas de respostas inapropriadas, entrada incorreta de dados, vieses dentre outros.

O modelo de análise de resultados da pesquisa foi organizado de modo a verificar primeiramente o modo como as organizações dos estudos de caso estão estruturadas, por meio do tópico "Estrutura da Empresa". A seguir são analisadas as questões pertinentes à implementação do sistema MES em si, em que serão observados os procedimentos e características presentes na adoção do MES em cada situação. O bloco destinado para esta finalidade será definido como "Implementação do MES". Finalmente, o último bloco de análise denominado como "Redução de Custos" detalha a situação vivenciada por cada empresa em termos de expectativas e resultados no que diz respeito à redução de custos. 


\section{ANÁLISE DOS RESULTADOS}

\section{CASO A}

\section{ESTRUTURA DA EMPRESA}

O primeiro estudo de caso foi realizado em um Grupo com unidade de escritório posicionada no município de São Paulo, e fábricas instaladas no interior do estado de São Paulo.

A empresa conta com um quadro de colaboradores extenso, visando à manutenção de um portfólio de produtos diversificado, aumento de mercado e ganhos de escala.

O Grupo atua em diversas frentes de negócios, dentre elas, a produção de fontes de energia, sendo que as linhas de produtos são compreendidas por alguns tipos, desenvolvimento de produtos alimentícios, cujas linhas de produto compreendem vários ingredientes naturais.

A unidade orientada a produção de energia apresenta estratégias de manufatura contínua, enquanto que a unidade produtora de produtos alimentícios está delineada para atender a manufatura intermitente, ou seja, produção por bateladas ou lotes.

A área participante desta pesquisa foi o departamento de sistemas de automação industrial, cujo gestor atua na área desde 2006.

A estrutura organizacional do grupo está dividida da seguinte maneira: 


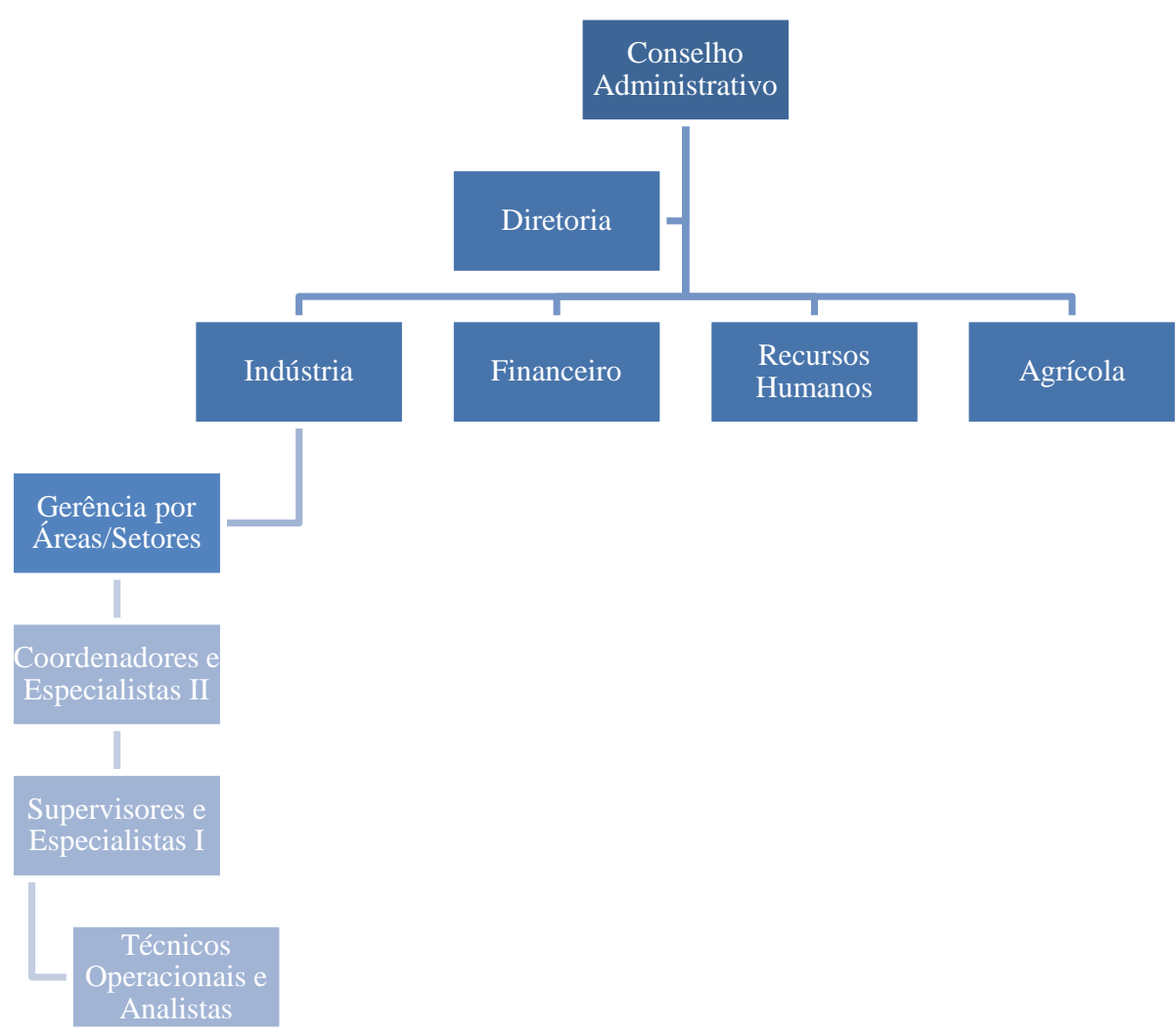

Figura 15 - Organograma de hierarquia, empresa A

FONTE: Figura elaborada pelo autor da obra.

\section{IMPLEMENTAÇÃO DO MES}

Na empresa A, não existe uma área específica dentro de TI para tratar de assuntos relacionados a investimentos em tecnologias. Normalmente, tais iniciativas são tratadas por um Comitê envolvendo representantes de diversas áreas, inclusive da Diretoria. Nas reuniões de Comitê são abordados diversos assuntos, dentre eles, as discussões e propostas de ideias as quais podem ser aprovadas, uma vez que exista um interesse e haja uma viabilidade para executá-las.

O Grupo procura adotar a integração de sistemas. Este fenômeno ocorre pelo fato do sistema ERP possuir uma abrangência muito grande, acarretando em impactos relevantes sobre o Grupo. Normalmente, a integração dos sistemas caminha no sentido de: 
1. Integrar sistemas legados e demais sistemas ao ERP, quando não se pode substituí-los definitivamente;

2. Utilizar módulos e ferramentas do próprio ERP.

Um dos traços da empresa é a presença do conceito de integração entre o sistema ERP e o MES. Na produtora de energia, o MES foi introduzido desde 2006, enquanto que a integração foi dada em 2010. O processo de implementação do sistema MES que foi iniciada em 2006, não transcorreu em simultaneidade com sua integração ao ERP. Tanto a implementação do MES quanto à integração ocorreram para solucionar determinados problemas da indústria. Na unidade produtora de alimentos, por sua vez, o MES foi inserido em 2010, com integração simultânea ao ERP.

A empresa já possui uma implementação consolidada de um sistema ERP de grande escala e também instalou recentemente o sistema MES. A empresa está muito satisfeita com o controle de custos. Assim é pouco provável que investirá em novos sistemas de informações nos próximos períodos.

Os critérios usados para a escolha do sistema MES são discutidos a seguir. Na área de sistemas de automação, bem como de automação básica, a empresa conta com uma parceria de longa data com uma das empresas de um grupo, que fabrica hardware e software de automação.

Como o produto de MES da fornecedora se mostrava adequado como solução para determinados problemas na indústria e também na área de sistemas de automação básica, sua escolha foi classificada como a mais apropriada, considerando também critérios de integração nativa com a cadeia de produtos de chão-de-fábrica da própria fornecedora.

Um dos principais desafios encontrados foi a questão das mudanças, como em muitas implantações de sistemas. As atividades, que até então eram feitas de um determinado modo, são extintas, e muitas outras são criadas.

Um grande desafio consiste em conseguir envolver toda a equipe do projeto e stakeholders do início ao fim do projeto, para estabelecer qual é a proposta do sistema MES, como a necessidade surgiu e como o sistema será implementado.

Deve-se informar sobre o que será afetado, os riscos envolvidos, as mudanças e as pessoas envolvidas, monitorando frequentemente o andamento das atividades e os desvios. Agindo assim, a passagem do sistema das mãos da equipe de implantação para os usuários 
transcorre de uma forma mais amena, permitindo a absorção de um conhecimento pleno sobre o sistema.

O conhecimento é essencial, porque, em última análise, os participantes das equipes irão manter o sistema depois de entregue e serão estes que ajudarão na construção das futuras soluções.

As principais diferenças entre o processo atual e o anterior em relação à coleta de dados de manufatura é que as soluções de MES criadas nas unidades contribuíram para a centralização das informações de determinados processos relacionados com a gestão do laboratório e do processo produtivo, por meio de um repositório único e acessível a todos.

Entre os objetivos básicos, pode-se apontar dois que estão relacionados com a desoneração das funções dos operadores, técnicos e analistas, tanto do laboratório quanto do processo:

1) Avaliar a necessidade e eliminar ou reduzir o número de informações digitadas ou escritas pelos operadores, técnicos e analistas em controle manuais, como planilhas e relatórios impressos descentralizados, através da coleta automática dessas informações em equipamentos e dispositivos de medição e controle do chão-de-fábrica;

2) Nos casos em que a coleta automática não é possível, avaliar a necessidade dos demais controles manuais e procurar sistematizar as informações digitadas e escritas, que passaram a ser feitas diretamente no MES.

Na unidade de energia, os benefícios estão mais relacionados com o objetivo 2, já que no sistema antigo já havia uma integração via banco de dados com equipamentos/dispositivos de medição de campo.

Já na unidade de produtos alimentícios, os benefícios estão relacionados com ambos os objetivos.

A decisão para usar o sistema na unidade de energia se deu porque havia um descontentamento com o sistema antigo de MES. A decisão pela substituição pareceu ser a decisão mais coerente a se seguir. 
O ERP também não cumpria uma série de atividades relacionadas com o monitoramento do processo de produção e de laboratório, por isso, existia uma lacuna a ser preenchida.

$\mathrm{Na}$ unidade de produtos alimentícios, o ERP já cumpria uma série de atividades relacionadas com o monitoramento do processo de produção e de laboratório, diferentemente da unidade de energia.

O MES foi instalado para desenvolver um papel mais apropriado ao seu caso, como fornecer informações no nível dos equipamentos, papel que o ERP não desempenhava e espelhando para o ambiente ERP. Estudou-se bastante o campo de atuação do ERP atual para evitar redundância de controles.

As informações que transitam no MES são de caráter "event based" (orientada por eventos/descontínuo/informação relevante), diferentemente de sistemas historiadores (orientada por tempo/contínuo/dados numéricos).

O MES trabalha com a coleta de informações de determinados eventos, eventos estes que são relevantes para o monitoramento. Basicamente, são divididas em entradas e cálculos. As entradas podem ser puramente digitadas ou coletadas automaticamente. Os cálculos são obtidos de forma automática, a partir do processamento das informações de entrada e de outros cálculos.

Os motivos que levaram a empresa adotar novos sistemas de informação foram basicamente a necessidade do negócio, deficiência de sistemas antigos (evidentes problemas de performance) e mudanças de legislação.

A avaliação da estabilidade dos sistemas atuais quando comparada aos controles manuais executados anteriormente está se consolidando.

A inovação ocorreu principalmente entre as equipes de operadores, técnicos e analistas do laboratório e do processo produtivo no sentido de contribuir para um amadurecimento do conhecimento sobre como os sistemas MES funcionam e de como podem ajudar a organizar a gestão dos processos de laboratório e de produção.

Intuitivamente, os colaboradores já concebem novas demandas por relatórios, indicadores e controles operacionais arquitetando modos de inseri-las dentro do sistema MES. Tal fenômeno reduz os controles manuais, o que evita as informações serem tratadas de forma exclusiva e passem a ser disseminadas para toda a organização. 
Em relação ao nível de envolvimento dos participantes no projeto, durante um período de 12 meses, a equipe de implantação do MES ainda fornece suporte em tempo integral, de até 24h, quando solicitado, às equipes de usuários do laboratório e do processo produtivo, em virtude de ajustes e aperfeiçoamentos no modelo originalmente proposto.

Depois disso, a equipe volta-se para um papel mais informativo, avaliando novas iniciativas e desvios de utilização do sistema, readequando-o quando necessário, a pedido das equipes de usuários.

\section{Características do MES:}

- Com a introdução do MES, houve um aprimoramento no processamento de informações e das consolidações diárias;

- Consolidações tornaram-se mais rápidas, em virtude de menos digitações manuais e também de uma revisão dos cálculos do antigo sistema;

- Monitoramento qualitativo e quantitativo dos processos industriais;

- Por meio da integração com o ERP, existe a baixa de ordens de processo para o MES simplesmente para que o MES determine o exato lote de cada ordem;

- Por se tratar de processo batelada, existia a possibilidade de se obter maiores informações sobre o processo produtivo dos produtos intermediários;

- Atualmente, o MES não retorna ao ERP os tempos reais de execução dos processos.

\section{Obstáculos:}

- Adaptação aos processos de mudança;

- Atividades extintas ou desempenhadas de outra forma;

- Garantir o envolvimento de toda a equipe do projeto e stakeholders, do início ao fim do projeto;

- Promover uma comunicação eficaz dos objetivos do MES, discutindo riscos e mudanças.

\section{Proveitos:}

- O sistema é fortemente customizável, permitindo várias possibilidades;

- Aumento da visibilidade, confiabilidade e centralização das informações;

- Agilização de determinados processos; 
- Obtenção de benefícios de curto prazo.

\section{Objeç̃es:}

- Risco de descontinuidade do software de MES adquirido;

- Risco de falta de suporte adequado;

- No caso de muitas necessidades não há solução standard;

- Existe o risco de se caminhar muito no sentido de customizações.

\section{Impactos na organização:}

- Frequentemente, projetos de MES fazem a organização repensar seus processos e se questionar sobre o que realmente agrega valor na sua cadeia produtiva;

- Os controles antigos foram extintos, pois se provaram sem efeito;

- A organização admite uma postura mais crítica sobre o que é ou não necessário.

No grupo, o MES foi inserido para substituir um sistema dedicado responsável pelo monitoramento qualitativo dos processos industriais, tais como, a digitação de informação pertinente aos laboratórios da indústria, análises físico-químicas e microbiológicas, além do quantitativo, dentre eles, dados relacionados à operação e à produção, balanços de produção e vários indicadores dos processos produtivos, tais como rendimentos, perdas, eficiências, controle de paradas, OEE, Overall Equipment Effectiveness de equipamentos e relatórios web customizados.

Com a introdução do MES, houve um aprimoramento no processamento dessas informações e, portanto, das consolidações diárias, que se tornaram mais rápidas, em virtude de menor volume de digitações manuais, e também de uma revisão dos cálculos do antigo sistema, com o objetivo de agilizar ainda mais o processamento do fechamento pelo MES.

As etapas do processo antigo eram formadas primeiramente pela anotação dos lotes consumidos por produto. Em seguida, os produtos consumidos eram posicionados próximos às máquinas para início da produção. O processo era executado e todos os dados relacionados à produção eram anotados manualmente no formulário físico ou inseridos através do sistema supervisório pelas telas dos terminais.

Com o MES houve maior controle sobre o processo de manufatura com precisão sobre as operações, evitando o contato direto do operador de máquina com retorno manual de dados 
ao sistema, o qual opera em dois sistemas simultaneamente, o sistema de batelada e o supervisório.

Com a entrada do MES, que é operado por diversos terminais, os operadores são distribuídos dentro das áreas, mas cada operador é responsável por monitorar até 02 (dois) equipamentos simultaneamente, enquanto os demais monitoram os equipamentos restantes.

Posteriormente, a integração com o ERP permitiu que uma série de indicadores do MES necessários para o custeio dos produtos da unidade de energia, pudessem ser integrados ao ERP por meio de uma carga única diária, sem a necessidade de redigitação. Todavia, não existia uma baixa de ordens de processo do ERP para o MES, pois não havia necessidade.

Os controles de lotes são feitos exclusivamente para os produtos acabados e, por se tratar quase que totalmente de processos contínuos, a rastreabilidade pode ser feita por determinação indireta conhecendo-se os lead-times entre os processos intermediários e analisando-se os dados e informações de todos os processos da cadeia.

As ordens de processo são mensais com apontamentos diários e não existe uma necessidade de estudo de capacidades e de quantidades, mas sim uma previsão de produções e de indicadores por mês, com base no SOP, Sales and Operations.

Contudo, na unidade de produtos alimentícios, a proposta foi semelhante, exceto pela área de laboratório e qualidade, já que o ERP desempenhava esse papel. Por se tratar de processo batelada, existia a possibilidade de se obter informações mais detalhadas acerca do processo produtivo dos produtos intermediários ou semi-acabados.

Por meio do acesso ao sistema supervisório de cada equipamento, com a entrada do MES, criou-se automaticamente uma abertura de folha do equipamento para apontamento de dados da produção. Com base no intervalo de aproximadamente 01 (uma) hora, o sistema calcula automaticamente os dados de produção e os lança na folha do equipamento, sem qualquer necessidade de apontamento manual.

Por esta razão, foi criada uma sistematização semi-automática com o intuito de monitorar os processos nos equipamentos, tais como o relacionamento entre lotes, ordens, produtos e equipamentos. Outro objetivo era manter a rastreabilidade de lotes, ordens, produtos e equipamentos, disseminar a substituição de planilhas de apontamentos dos processos ao longo das bateladas por registros operacionais automáticos, controle de paradas, OEE de equipamentos e emitir relatórios web customizados. 
Com a integração com o ERP, existe a baixa de ordens de processo para o MES simplesmente para que o MES determine o exato lote de cada ordem, auxiliando a operação na escolha do lote e seu posterior envio ao ERP. Outras informações de lista técnica e receitas são transmitidas pelo ERP, mas atualmente não possuem serventia.

O MES não retorna ao ERP os tempos reais de execução dos processos. Já o estudo de quantidades é feito no ERP, com base nas listas técnicas e no SOP. Porém estudo de capacidades não é realizado. Atualmente este estudo é desempenhado de forma manual e direcionado apenas aos equipamentos considerados como gargalos.

O MES atua como um sistema de históricos inteligente para armazenagem de eventos relevantes ao processo, com cruzamento de dados. Mede-se cada variável, com armazenagem direta no banco de dados otimizado.

Assim, conforme cada batelada por equipamento, o MES coleta os dados durante a manufatura, associando as informações de parada, lote e produto produzido. A partir do MES, outros sistemas podem extrair informações também.

A avaliação dos custos de hora-homem seria uma proposta interessante para a gestão da fábrica. Atualmente já é possível identificar uma redução de tempo gasto nas operações, e atualmente já existe um monitoramento do processo para garantir a estabilidade do processo, garantindo maior autonomia e tempo livre para os supervisores do chão-de-fábrica investirem tempo em outras atividades.

$\mathrm{Na}$ unidade de produtos alimentícios com maior divisão de áreas, estas características tornam o processo e as operações mais lentas, já que há um número reduzido de operadores. Assim, é preciso cobrir as demandas por setup, verificar os consumos, acompanhar a produção, além de realizar as análises de automação.

Não é preciso mais que o responsável pela operação cheque em qual o momento uma batelada é iniciada. Previamente havia esta demanda, uma vez que o sistema batch via web não existia. Todas as áreas consultam o MES e podem extrair dados por meio de relatórios web.

Como alternativa, foi desenvolvido um quadro onde se realiza a gestão à vista, que por sua vez torna possível interagir e atuar para compreender quais são as informações corretas, com maior flexibilidade e mapeamento de rotas, ou possibilidade de manter as rotas manuais com opções em aberto. À medida que as rotas forem sendo cumpridas, os sinalizadores do painel mudam de cor, seguindo o core do módulo no MES. 
No resumo, para a unidade de energia, com processos contínuos e sem paradas, o MES ofereceu melhorias diretas no chão-de-fábrica, retornando os dados, o que ajuda a dimensionar de forma mais rápida. Acerca dos benefícios quantificados seria necessário investigar com mais clareza os benefícios quantificados a partir dos registros de documentos e visibilidade de informações originados de uma ferramenta única.

$\mathrm{Na}$ unidade de produtos alimentícios, embora haja o domínio do uso do MES na empresa, as prioridades do chão-de-fábrica são alternam repentinamente, de modo que os projetos de acompanhamento e melhoria apresentam dificuldades de serem concluídos. Seria preciso ter uma proposta de visão do problema a ser resolvido e estabelecer quais ferramentas seriam usadas para reduzir ou mitigar o problema.

Atualmente não há uma forma atuante de retroalimento e há muita preocupação em atender demandas de curto prazo, como formulação de relatórios para as áreas, reuniões, reportes a gerência.

Foi apontada uma escassez de tempo para calcular efetivamente o ganho, já que muito é investido na discussão de problemas e não discussão da melhoria em si, atacando a causa de modo analítico.

É reconhecida a necessidade de investimentos em recursos para acompanhar o dia-a-dia da operação, pois hoje há escassez de tempo para que a equipe responsável pelo chão-de-fábrica possa se dedicar aos planos de melhoria sem comprometer a operação.

\section{REDUÇÃO DE CUSTOS}

Para compreender a redução de custos, seria necessário fazer um levantamento mais extenso para identificar todos os departamentos que utilizam informações do MES para alimentar o ERP.

Atualmente não existe uma clara visão de como, quando e onde exatamente as informações do MES são utilizadas para a determinação dos custos de produção. Tampouco é possível fornecer uma estimativa de tempo gasto nessa atividade. Ainda, acredita-se que muitas informações podem estar sendo digitadas manualmente. 
Assim, um levantamento mais preciso seria essencial para definir quais as informações estão sendo utilizadas, quem as digita, quanto tempo é dispendido nessa digitação e os quais os benefícios em automatizá-las.

A quantificação dos benefícios percebidos em torno da redução de custos pode ser melhor identificada e é mais palpável quando o MES é analisado de forma isolada, em detrimento da perspectiva a partir da integração com o sistema ERP, já que são duas formas de visão distintas ao se analisar a questão de redução de custos. É bastante complexo identificar e relacionar quais informações são inseridas no ERP, por qual departamento e por quais colaboradores, já que as informações são acessíveis a todos da empresa.

No geral, os resultados superaram as expectativas, porém há uma grande dificuldade em equacionar o legado do projeto de forma quantitativa. A visão dos gestores em relação à redução de custos é de que tanto a implantação do MES quanto a sua integração com ERP reduz custos, porém há uma dificuldade em se contabilizar e mensurar esta redução.

Pode-se observar que houve uma economia de custos, em relação à agilidade na disponibilização da informação e à desoneração da carga de trabalho dos operadores, técnicos e analistas, uma vez que o processo de se obter informações foi muito aprimorado e agilizado. Tal fato permite que o operador possa dedicar mais tempo auxiliando na gestão do processo em si.

Em um nível hierárquico mais alto, a própria gestão reconheceu que a análise de seu trabalho passou a ser facilitada, pois a qualidade das informações também melhorou. A partir dos dados gerados, foram criados indicadores que permitem uma reação preventiva mais rápida quando uma tendência ruim é detectada.

O tema da redução de custos pode recair sobre a questão de se dimensionar e definir o que realmente originou a redução de custos, antes e após o MES.

Existem vários fatores que podem influenciar na redução. Por exemplo, sobre a contratação de pessoal que foi reduzida desde alguns anos atrás, não se pode inferir que o MES foi responsável por este fenômeno. Outro exemplo interessante pode ser a troca de equipamentos. Uma vez identificado um problema recorrente no equipamento, esta máquina pode ser substituída e oferecer menor demanda por manutenção. Quando substituída, o volume de reclamações e manutenção é reduzido. Em contrapartida, é muito complicado mensurar esta ação em conjunto com o MES para verificar quem é elemento responsável pela redução de custos. 
Em uma indústria com nível de automação robusto e atividades mais específicas, a verificação destes dados pode ser facilitada.

Logo, ao analisar uma eventual redução, deve-se isolar as diversas variáveis, compreender o contexto de análise, criar os grupos de controle, verificando os efeitos causados por estímulos, e levantar uma estatística mensal para entender o comportamento diante de diversas variáveis.

Na unidade produtora de alimentos, a iniciativa mais impactante para a redução de custos se deu pela automatização da coleta de dados operacionais. Antigamente, os operadores tinham que se dedicar, em intervalos de 01 hora, durante todo o tempo de cada batelada, para preencher manualmente um formulário em papel com os valores de, na média, 20 instrumentos de campo, em pelo menos 15 equipamentos diferentes.

Para a unidade produtora de energia, por se tratar de um processo contínuo e sem paradas, os benefícios percebidos foram mais discretos, no sentido de que a melhoria no chãode-fábrica não ficasse tão perceptível. Obviamente, algumas melhorias foram notáveis como a documentação de registros, apontamentos, visibilidade de informação e a unificação de ferramentas. Com o MES retornando os dados ao ERP, pode-se auxiliar no dimensionamento de volumes de trabalho de forma rápida.

O MES permitiu que os colaboradores pudessem ter um acesso a dados mais detalhados, como o controle do OEE, o MTBF, Mean Time Between Failures, o MTTR, Mean Time to Repair, registros de paradas, fechamentos de $\mathrm{OP}$, mas isto não significa necessariamente que os colaboradores estejam tomando as ações necessárias para de fato reduzirem os custos a partir desta visibilidade. Atualmente, sem dúvida, há um maior controle e precisão sobre uma análise, evitando que haja uma intervenção muito intensa do operador com o sistema.

Na unidade de produtos alimentícios, o MES é bastante útil para a extração de relatórios operacionais. Antes do MES, o operador identificava e marcava o lote, verificando o produto a ser manufaturado. A seguir a máquina recebia os insumos, executava-se o processo de fabricação e posteriormente, os apontamentos eram registrados no papel. Portanto, o processo envolvia muitas etapas manuais.

O sistema supervisório era utilizado para abertura da folha do equipamento. A partir do MES, a abertura desta folha passou a ser automática em um intervalo de tempo de 01 hora. Assim, pode-se obter todos os dados calculados automaticamente pelo MES, sem qualquer apontamento manual. 
$\mathrm{Na}$ avaliação do custo de hora-homem houve uma proposta interessante do MES. A partir da implementação do sistema, pode-se identificar uma redução no tempo de produção. Os recursos humanos em conjunto com os sistemas eram designados a monitorar os processos, além de desempenhar outros papeis simultaneamente.

O MES pode ser bastante útil, uma vez que se estratifique adequadamente os motivos das paradas causadas pelas quebras de equipamentos ou improdutividades, como por exemplo, uma quebra de peça. É preciso identificar a causa raiz, enxergar e analisar um problema. Devido ao problema identificado pode-se partir para uma ação efetiva, e trabalhar de forma proativa. Assim, pode-se evitar que um determinado problema ocorra.

Então haveria uma possibilidade maior em se quantificar os ganhos obtidos em redução de custos. Atualmente, há uma carência no que diz respeito ao trabalho conjunto entre a operação e a manutenção, além de envolver a equipe participante do projeto. Acredita-se que com uma medida de aproximar os membros e incentivar o trabalho em conjunto seria possível obter um ganho ainda mais significativo. 


\section{CASO B}

\section{ESTRUTURA DA EMPRESA}

$\mathrm{O}$ primeiro caso exposto neste estudo refere-se à empresa $\mathrm{B}$ direcionada para $\mathrm{O}$ desenvolvimento de produtos para controle, proteção e distribuição de energia e produtos para supervisão e proteção de sistemas elétricos, cujas linhas de produtos são distribuídas entre bens de bens de capital durável e componentes elétricos.

Além de atuar no mercado brasileiro e possuir duas fábricas, a empresa exerce atividades de exportação para os Estados Unidos, América Latina, Ásia e Oriente Médio. Já a estrutura organizacional da empresa B é organizada da seguinte forma:

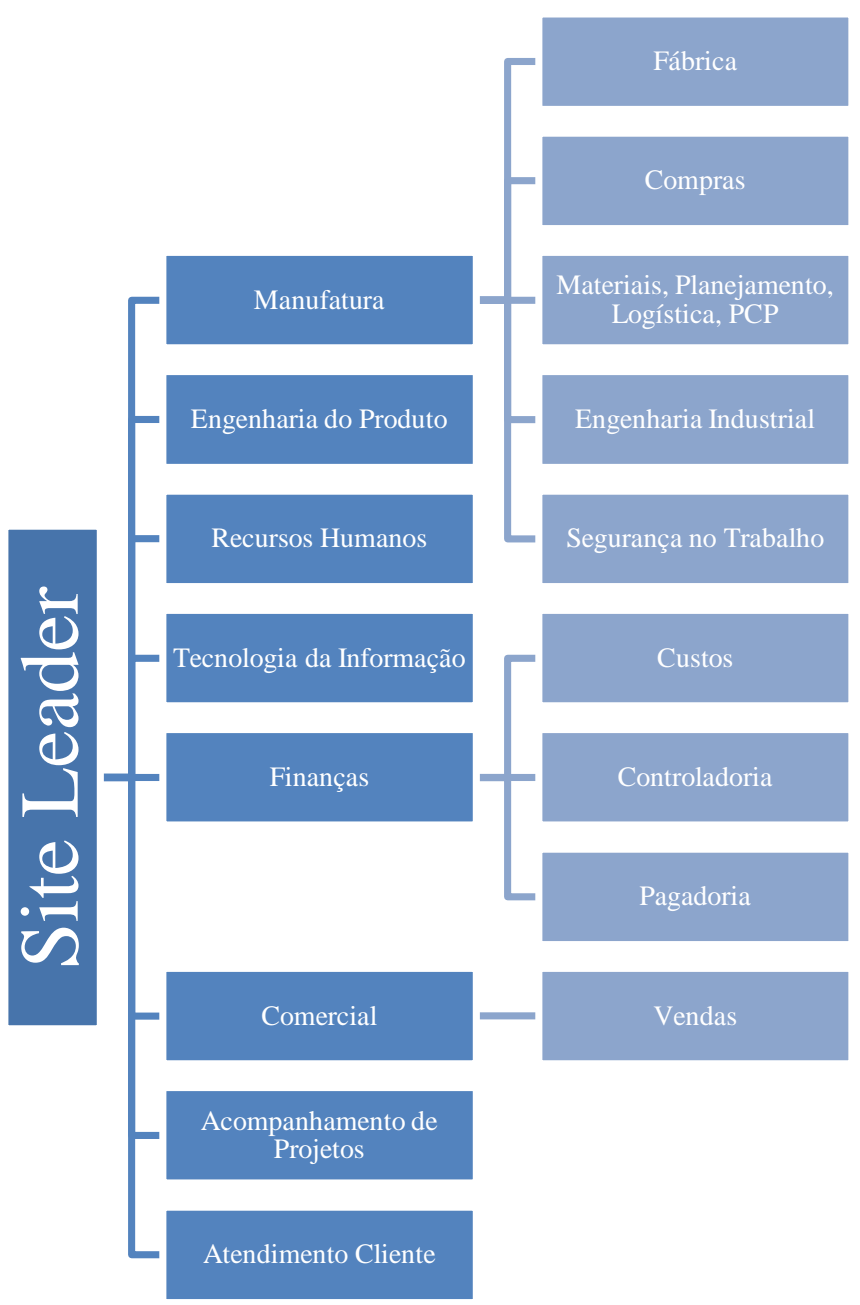

Figura 16 - Organograma de hierarquia, empresa B FONTE: Figura elaborada pelo autor da obra. 


\section{IMPLEMENTAÇÃO DO MES}

No caso da empresa B, identificou-se que para implementações específicas, como no exemplo do sistema MES, não existe uma área específica de Tecnologia da Informação (TI) designada para tratar de assuntos relacionados a investimentos em tecnologias.

Cada departamento é responsável por decidir os investimentos necessários e identificar as demandas por sistemas específicos, como o MES, conforme as carências. No entanto, cada área conta também com o respaldo de TI na implementação.

Em contrapartida, para projetos de maior dimensão, como a implementação do sistema ERP, há uma área global de TI responsável pelas análises e decisões a respeito de investimentos, sendo que os sites possuem autonomia para liberar e organizar os recursos que devem participar da implantação.

Conforme apurado, os fatores mais relevantes no momento da decisão de implementação de novos sistemas são o atendimento de demandas específicas de cada área, os custos relacionados à implementação e a análise do índice Return On Investment (ROI).

A decisão de implementação parte das áreas que originaram a solicitação, com o suporte decisório das áreas financeiras e TI, de modo que a área financeira priorize fatores como a viabilidade do projeto e o cálculo do ROI e TI disponibilize os elementos necessários para que a execução do projeto se faça possível.

Na empresa B, existem muitos softwares classificados como stand-alone, ou seja, sistemas que operam de forma autônoma e que não dependem de outros programas para funcionar corretamente e que também são integrados ao ERP através de desenvolvimento de interfaces.

Assim, é possível observar que muitos elementos de integração de sistemas de informação se fazem presentes no ambiente da empresa B. Identificou-se que existe um conceito claro de integração entre os sistemas ERP e MES disseminado na organização e que inclusive encontra-se em processo de finalização.

A partir deste conceito a empresa procurou se informar a respeito dos fornecedores do sistema MES. A seguir são descritos os fatores considerados para a escolha do MES. Dentre os vários fatores decisivos para a escolha do MES, os fatores considerados de maior peso para a decisão do software MES são o custo total do projeto, tempo de implementação, e disponibilidade de ferramentas oferecidas comparadas às opções desejadas pela área. 
Dentre os fatores que motivaram os investimentos em sistemas são citados alguns. A empresa optou pelos investimentos em circunstâncias em que não era possível efetuar a gestão efetiva da manufatura, ou até mesmo acompanhar a evolução das ordens de produção. Tampouco era possível efetuar um planejamento produtivo com qualidade, já que não existia um conhecimento dos tempos reais de cada grupo de tarefas.

Podiam ser notados também outros fatores que motivaram a busca por novas soluções de sistemas, tais como o nível baixo de atendimento ao cliente no prazo, elevado valor de inventário em processo, além de comprometer as tomadas de decisão por falta de visibilidade na manufatura. Desta forma, por meio de um estudo de caso foi possível demonstrar a necessidade de investimentos em novos sistemas e projetos cujos ROI fossem projetados para aproximadamente 1,5 (um e meio) anos.

Desta forma, a empresa buscou no mercado um software de planejamento de produção com capacidade finita. Essa iniciativa permitiu que a empresa percebesse a necessidade de se medir a execução dos trabalhos de manufatura para poder obter a qualidade no planejamento, e assim houve a decisão de adquirir uma solução que pudesse atender a estes requisitos em conjunto com as soluções já existentes. A corporação decidiu investir para obter uma melhoria no prazo de entrega de seu produto.

A implementação do MES transcorreu em um primeiro momento, sem a integração completa. Os dados referentes à configuração de produtos e das rotas fabris foram alimentados por meio do ERP e os dados de execução foram coletados via MES.

No caso da empresa B, o produto final é custeado com base no planejamento de horas para execução, sendo que todas as cargas horárias incrementais utilizadas em produção são consideradas como improdutivas nos livros fiscais.

Contudo, na segunda fase do projeto os dados de execução da manufatura passaram a retornar ao sistema ERP. Este fato permitiu que o valor real apontado custeasse o produto e a engenharia passasse a exercer um papel mais atuante na interpretação das divergências encontradas entre os valores reais e planejados.

Tal situação contribui para que a área de engenharia possa atuar de fato em adaptações de processos fabris ou detectar oportunidades de melhoria, que é o objetivo central traçado no início da implementação. Em resumo, os dados reais do chão-de-fábrica são coletados e manipulados via MES e através de interface são transmitidos aos sistemas gerenciais ERP, gerando impactos e inovações mais relevantes na área de manufatura. 
A seguir destacam-se as principais modificações de processo em decorrência da implementação do MES:

Informe dos horários de início e término das operações controladas para cada ordem de produção pelos operadores;

$>$ Informe dos horários de início e término de paradas não planejadas para cada ordem de produção pelos operadores;

$>$ Organização de encontros liderados pela área de Engenharia Industrial para discussão de tempos reais e planejados;

$>$ Análises pelos gerentes de fábrica sobre o tempo de paradas não planejadas, junto aos supervisores de células.

A seguir, são discorridas as principais diferenças entre o processo atual e o anterior em relação à coleta de dados de manufatura. Por um período, a empresa manteve um processo de coleta manual de dados, em que o operador marcava em cartões o seu horário de início da jornada, além de eventuais paradas ocorridas durante o dia e seu final de jornada, sem manter uma relação com a ordem de produção.

No atual processo, o operador se desloca até um ponto de coleta de dados, efetua a leitura de códigos de barra da ordem de produção, do seu crachá e a tarefa/parada que está executando.

Assim, por meio do sistema o operador é capaz de registrar o início e o término de cada tarefa, liberando relatórios a qualquer instante sobre a situação real da fábrica, com recursos trabalhando e parados, utilização dos recursos, tempos parados, entre outros.

Devido à recente instalação do sistema MES e integração junto ao ERP, de aproximadamente 06 (seis) meses, uma análise mais profunda entre os controles automáticos atuais e o processo anterior e manual será possível mediante o decorrer do tempo, já que não era possível extrair dados que fossem úteis.

Sendo possível averiguar a estabilidade dos sistemas quando comparada aos controles manuais executados anteriormente. Entretanto, inicialmente já foi possível detectar um maior impacto de inovação recaindo sobre a área de Manufatura.

Um dos grandes desafios do projeto consistiu em encontrar meios para envolver os participantes do projeto de modo mais intenso. Foi identificada a necessidade de disponibilizar 
mais recursos junto à equipe de operação para as fases de testes e desenvolvimento do sistema. Além disso, foi relatada a necessidade de uma maior sintonia entre a gerência de fábrica e engenharia, risco frente ao sindicato da categoria, alto custo do treinamento e manutenção do conhecimento.

Explicitando as principais características do sistema MES implantado na organização, foram elencados os obstáculos de implantação, proveitos e adversidades obtidos no processo, além dos impactos na organização:

\section{Características do MES:}

- Coleta de dados via código de barra, com pontos de coleta próximos aos operários;

- Acesso aos relatórios para toda a supervisão e níveis hierárquicos superiores via intranet;

- Customização do produto e vários pontos do processo, como por exemplo, as tarefas onde o custo do apontamento seria superior ao custo da operação (pequenas operações) ou apontamento em lotes (tratamentos térmicos);

- Relatórios em tempo real;

- Falta da implantação do pacote de OEE.

\section{Obstáculos:}

- Envolvimento dos participantes do projeto de modo mais intenso;

- Alinhamento de expectativas dos usuários e participação nas solicitações de customizações;

- Trabalhar a percepção do MES frente aos usuários;

- Necessidade de disponibilizar mais recursos junto à equipe de operação para as fases de testes e desenvolvimento do sistema;

- Necessidade de sintonia e engajamento entre fábrica e engenharia;

- Risco frente ao sindicato da categoria;

- Alto custo do treinamento;

- Manutenção do conhecimento. 


\section{Proveitos:}

- Visibilidade clara dos processos fabris;

- Bom comparativo entre o plano e a realidade;

- Visão dos problemas que cada área da fábrica apresenta através dos tempos de parada;

- Melhoria no planejamento da produção;

- Melhoria e acompanhamento no comprometimento de cada operário;

- Facilidade na criação de vários projetos de melhoria de produtividade;

- Aumento na competência administrativa dos supervisores de área.

\section{Objecões:}

- N/A

\section{Impactos na organizacão:}

- Aumento no conhecimento do processo fabril e na formação de preços;

- Aumento da integração operário x liderança.

\section{REDUÇÃO DE CUSTOS}

Em relação à redução de custos em si, o caso B demonstra que a finalização da segunda fase será muito oportuna para avaliar a superação das expectativas em torno do investimento executado para o uso do sistema MES.

Os investimentos realizados e os custos para implementar o MES terão retorno após a conclusão da segunda fase do projeto, em que será possível analisar em detalhes o rendimento do MES.

Sobretudo, ficou evidenciado que a implementação do MES em si, não é a única responsável pelas melhorias e reduções de custos, mas sim, contribui para a geração de informações que por sua vez, oferecem um maior número de opções para que os gestores da companhia possam optar pela adoção de novas técnicas e disseminar novos conceitos, além de investir em novos projetos de melhoria.

Caso a empresa opte por não utilizar a informação para a geração de projetos de melhoria, não haverá o resultado desejado, já que o MES por si só não consegue mudar processos dentro da empresa. 
O MES pode ajudar a aumentar a visão dos gestores, mensurar e auxiliar na leitura e interpretação de dados por parte da Engenharia Industrial, para que tenham as condições de atuar na causa raiz dos problemas. No entanto, a relação entre o MES e a redução de custos não seria uma relação de causa e efeito obrigatoriamente.

Descrevendo brevemente as medidas ou métodos adotados para otimizar a redução de custos de produção nos últimos 03 (três) anos, a empresa credita a ações sobre investimentos em projetos de melhoria de produtividade, com base na experiência de engenheiros de processo ou ideias de operários.

Em razão da fase do projeto foram percebidas algumas melhorias em áreas isoladas, que renderam uma redução de custo, principalmente no que diz respeito à identificação de fatores que geram desperdícios.

Até o momento a percepção dos gestores em relação ao uso do conceito de integração entre ERP e MES é bastante positiva para a redução de custos, já que, por meio dos dados coletados, existem muitas oportunidades de melhoria que antes não eram visíveis para a fábrica e que têm potencial contínuo para gerar novas reduções de custos.

Acredita-se, no entanto, que futuramente com a posse de dados mais apurados, seja possível observar a geração de mais projetos de melhoria frente aos recursos oferecidos pelo MES, o que poderia gerar reduções de custos consideráveis.

Dentre as iniciativas mais relevantes para a redução de custos, pode-se citar que o grupo de melhorias contínuas, liderado pela Engenharia industrial, passou a assumir responsabilidades e tomar a frente dos dados de paradas de forma a buscar continuamente onde estão localizadas as oportunidades de redução de custos através do aumento de produtividade.

Os principais fatores de redução de custos elencados no caso B são detalhados a seguir, assim como o grau de importância e impacto nas operações de cada um destes fatores. $\mathrm{O}$ fator neste caso refere-se aos principais atributos que, segundo um ponto de vista, possam ter sido responsáveis pela redução de custos, verificando o impacto gerado para cada um deles. 


\section{Fator 01: Produtividade do Operário}

Impacto: Alto

Detalhes: Em relação à redução de custos em si, o caso B demonstra que a finalização da segunda fase será muito oportuna para avaliar a superação das expectativas em torno do investimento executado para o uso do sistema MES.

Os investimentos realizados e os custos para implementar o MES terão retorno após a conclusão da segunda fase do projeto, em que será possível analisar em detalhes o rendimento do MES.

Sobretudo, ficou evidenciado que a implementação do MES em si, não é a única responsável pelas melhorias e reduções de custos, mas sim, contribui para a geração de informações que por sua vez, oferecem um maior número de opções para que os gestores da companhia possam optar pela adoção de novas técnicas e disseminar novos conceitos, além de investir em novos projetos de melhoria.

Caso a empresa opte por não utilizar a informação para a geração de projetos de melhoria, não haverá o resultado desejado, já que o MES por si só não consegue mudar processos dentro da empresa.

O MES pode ajudar a aumentar a visão dos gestores, mensurar e auxiliar na leitura e interpretação de dados por parte da Engenharia Industrial, para que tenham as condições de atuar na causa raiz dos problemas. No entanto, a relação entre o MES e a redução de custos não seria uma relação de causa e efeito obrigatoriamente.

Descrevendo brevemente as medidas ou métodos adotados para otimizar a redução de custos de produção nos últimos 03 (três) anos, a empresa credita a ações sobre investimentos em projetos de melhoria de produtividade, com base na experiência de engenheiros de processo ou ideias de operários.

Em razão da fase do projeto foram percebidas algumas melhorias em áreas isoladas, que renderam uma redução de custo, principalmente no que diz respeito à identificação de fatores que geram desperdícios.

Até o momento a percepção dos gestores em relação ao uso do conceito de integração entre ERP e MES é bastante positiva para a redução de custos, já que, por meio dos dados coletados, existem muitas oportunidades de melhoria que antes não eram visíveis para a fábrica e que têm potencial contínuo para gerar novas reduções de custos. 
Acredita-se, no entanto, que futuramente com a posse de dados mais apurados, seja possível observar a geração de mais projetos de melhoria frente aos recursos oferecidos pelo MES, o que poderia gerar reduções de custos consideráveis.

Dentre as iniciativas mais relevantes para a redução de custos, pode-se citar que o grupo de melhorias contínuas, liderado pela Engenharia industrial, passou a assumir responsabilidades e tomar a frente dos dados de paradas de forma a buscar continuamente onde estão localizadas as oportunidades de redução de custos através do aumento de produtividade.

Os principais fatores de redução de custos elencados no caso B são detalhados a seguir, assim como o grau de importância e impacto nas operações de cada um destes fatores. O fator neste caso refere-se aos principais atributos que, segundo um ponto de vista, possam ter sido responsáveis pela redução de custos, verificando o impacto gerado para cada um deles.

\section{Fator 02: Perdas com Logística}

Impacto: Alto

Detalhes: Existia em toda a manufatura uma reclamação do atendimento da área de Logística, que não era considerado, nem pela Logística e tampouco pela Engenharia Industrial. Atualmente, os dados sugerem mudanças de layout e de processo logísticos, aumentando a produtividade.

\section{Fator 03: Ferramentas Inadequadas}

Impacto: Médio

Detalhes: Várias trocas de ferramenta e setups desnecessários tornam-se visíveis a partir da implantação do MES, incluindo possibilidades de customizações no sistema. O MES permite também controlar fatores como a necessidade de troca de ferramentas e também o cálculo de absenteísmo.

Além disso, o MES apresentou opções para controle de produtos, alinhamento e previsão de vendas, maior precisão de orçamentos realizados, maior efetividade no cálculo do custo da operação, da mão-de-obra e do consumo de material. O MES permite também que os 
operadores verifiquem e organizem suas atividades e suas respectivas prioridades de execução.

A implementação do MES pode contribuir, fornecer subsídios, gerar trabalhos de produtividade e até mesmo incentivar programas de melhoria contínua como o Kaizen, o Lean Manufacturing, ajustes de layout, e manutenção, podendo ocasionar uma redução de custos. $\mathrm{O}$ MES poderia ajudar a perceber determinados pontos que sem algum tipo de sistema, poderia haver uma complexidade maior. Contudo, as melhorias são advindas de uma ação específica e direta sobre a gestão da manufatura. Caso contrário, a instalação por si só pode tornar o MES improdutivo.

Os resultados advindos do MES dependem também da maturidade de processos e tarefas que a organização apresenta para que esforços sejam convertidos em ganhos de capital propriamente ditos.

Como exemplo, no caso B foi citado o implante do método de reposição de materiais por Kanban e modificações no layout da fábrica para redução de movimentações desnecessárias. 


\section{CASO C}

\section{ESTRUTURA DA EMPRESA}

O terceiro caso consiste na análise de uma empresa fabricante de embalagens de diversos tamanhos. Por meio de modernas técnicas de gestão integrada, excelência operacional, disseminação de conhecimento, e investimentos em tecnologias a empresa é uma referência mundial na área de atuação.

Contando com várias unidades fabris no país, a organização investe em planos de assistência técnica, capacitação de profissionais, manutenção integrada de equipamentos, aumentando a produtividade das operações.

O controle de custos e desempenho de processos e produtos é fator fundamental para atingir objetivos de superação das expectativas dos clientes, assim como incentivar ações de inovação.

Algumas ações são extremamente importantes para desenvolver as capacidades e ser competitivo no mercado atual. É preciso aumentar a disponibilidade e a eficiência das linhas de produção, assim como reduzir as perdas no processo produtivo e estabelecer padrões nos processos de produção.

Existem também operações específicas que consistem nas atividades desempenhadas nas próprias unidades de embalagem e que possuem o objetivo de aperfeiçoar a melhoria contínua dos processos.

Estas ações são refletidas no gerenciamento logístico no fornecimento dos produtos, redução de custos operacionais e eliminação de perdas e desperdícios.

A área participante desta pesquisa foi o departamento de gestão industrial, cujo gestor atua na área desde 2003.

A empresa é estruturada de forma hierárquica e verticalmente, segundo o modelo tradicional. O organograma é apresentado na Figura 17: 


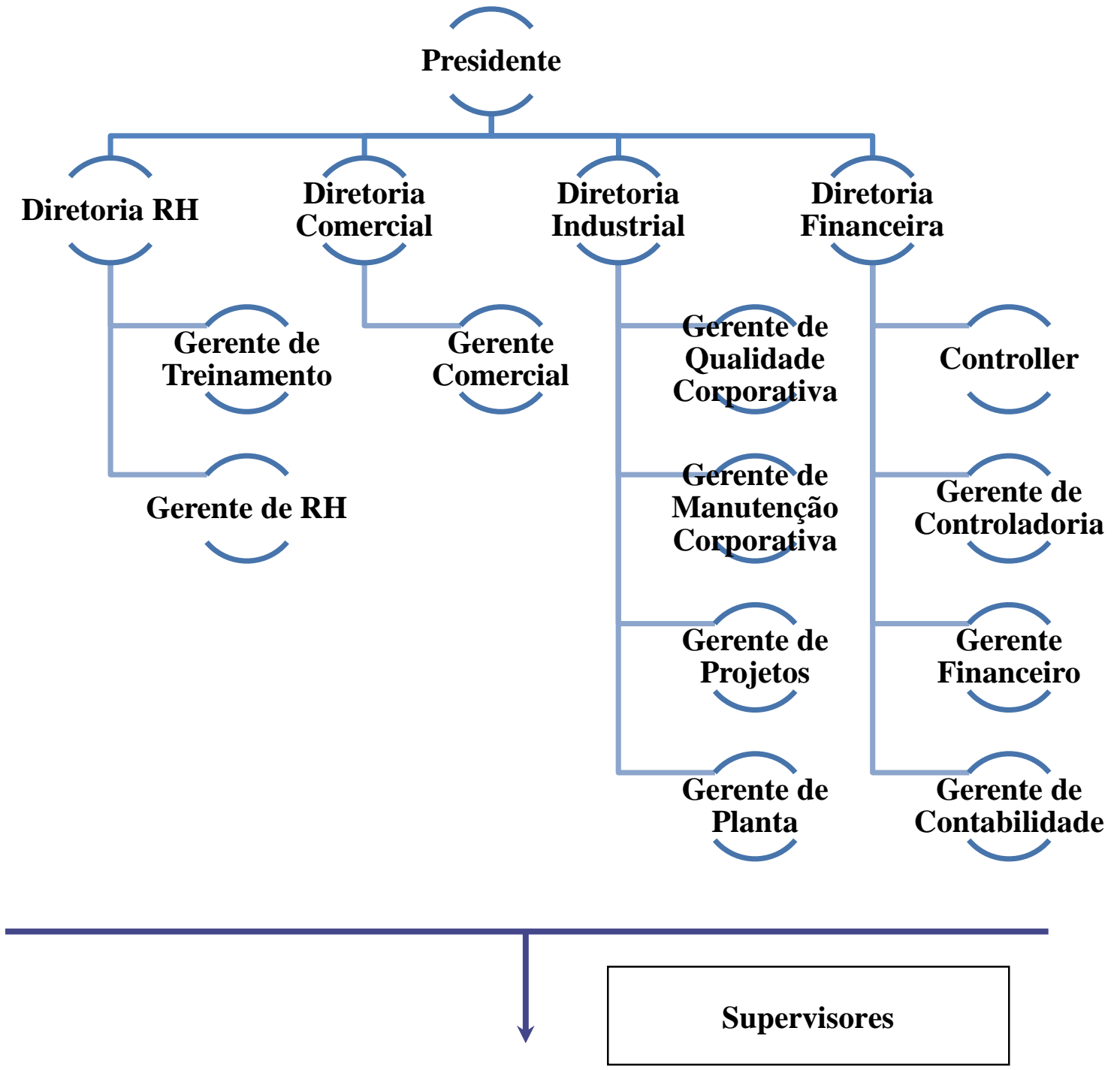

Figura 17 - Organograma de hierarquia, empresa $\mathrm{C}$

FONTE: Figura elaborada pelo autor da obra.

\section{IMPLEMENTAÇÃO DO MES}

Existe hoje um departamento específico de TI para tratar de assuntos relacionados a investimentos em tecnologias. Trata-se de um setor terceirizado de uma empresa especialista no ramo.

Os investimentos necessários são expostos pelo departamento de TI e também por outros departamentos que recorrem à área de TI para as especificações técnicas, que ao final são aprovados ou rejeitados pela diretoria. 
Dentre os fatores utilizados para a implementação de novos sistemas, é verificado que a implementação de novos sistemas deve resultar em alguma melhoria financeira, produtiva com relação a processos, de qualidade, ou ser inevitável em função de obsolescência ou vantagem estratégica. A decisão de efetuar o desembolso para o investimento sempre cabe à diretoria.

Os motivos que levaram a empresa adotar novos sistemas de informação foram a necessidade de atualização, redução de custos, maior controle de processo, melhoria em análises e controle estatístico do processo.

Para a seleção do MES foram utilizados os critérios técnicos e de custo. A coleta de dados atual é realizada via sistema supervisório. Diversos outputs dos equipamentos são monitorados e dados são armazenados em planilhas.

A implementação de sistemas partiu de uma necessidade para integração entre áreas. Os sistemas sempre são e foram implementados devido as análises de retorno em investimento ou pelos outros motivos supracitados.

A empresa possui uma implementação consolidada de um ERP nacional de grande escala e também instalou recentemente o sistema MES em uma de suas unidades, cujo fornecedor é uma empresa renomada e de elevado conhecimento. $\mathrm{O}$ processo de instalação ocorreu paulatinamente.

Muito provavelmente, haverá investimentos de curto e médio prazo em softwares justamente na implantação do MES na unidade em que a área participante foi entrevistada para atender as demandas peculiares a manufatura discreta.

A empresa adota o ERP e está em processo de implementação integral do MES, todavia, estes sistemas ainda não se comunicam.

O MES está principalmente sendo utilizado como uma ferramenta sofisticada de monitoramento de parâmetros de processo, de desempenho de equipamentos, tempo de parada, tempo médio entre paradas, entre outros.

O MES ainda não é empregado como um sistema que altera parâmetros de forma autônoma, já que quaisquer mudanças ainda são feitas por colaboradores com acompanhamento no próprio local.

De um modo geral, a maioria das informações do chão-de-fábrica são gerenciadas e alimentadas automaticamente ao sistema de Controle Estatístico de Processo, o Datalyzer. 
Algumas informações ainda são manualmente alimentadas em planilhas e ainda podem ser gerenciadas por meio de relatórios.

A estabilidade e a confiabilidade dos dados gerados automaticamente pelos sistemas são maiores do que aqueles comparados os dados lançados manualmente, com inovações e impactos mais reconhecidos na área de chão-de-fábrica e com alto nível de envolvimento dos participantes, iniciando na definição do escopo original e terminando no comissionamento ou debugging do sistema.

\section{Características do MES:}

- Processo de implementação do MES ainda em consolidação;

- Não há evidência de integração entre o ERP e o MES, mas a pretensão de realizá-la no futuro;

- Ferramenta sofisticada de monitoramento de parâmetros de processo;

- Utilizado para medir o desempenho de equipamentos, tempo de parada e tempo médio entre paradas;

- Algumas informações ainda são manualmente alimentadas em planilhas;

\section{Obstáculos:}

- A resistência à mudança foi um dos principais desafios encontrados ao longo do processo de instalação dos sistemas.

\section{Proveitos:}

- Automatização na coleta de dados;

- Promover a integração entre as áreas;

- Maior estabilidade e confiabilidade dos dados gerados;

- Alto nível de envolvimento dos participantes.

\section{Objecões:}

- MES não é utilizado para modificar parâmetros de recursos produtivos de máquinas, com intervenção humana, caso necessário. 


\section{$\underline{\text { Impactos na organização: }}$}

- Inovações geradas e percebidas principalmente no chão-de-fábrica;

- Os impactos estão sendo avaliados, devido ao momento de implementação em que o MES se encontra.

\section{REDUÇÃO DE CUSTOS}

Pode-se dizer que a opinião da empresa em respeito às ferramentas disponíveis para o controle de custos atual é muito satisfatória, uma vez que o departamento de controladoria possui levantamentos detalhados dos custos e despesas da empresa.

Todavia, com o projeto do MES ainda em andamento, acredita-se que futuramente muitos benefícios em termos de redução possam ser rendidos.

As principais expectativas em relação ao MES estavam relacionadas à geração de relatórios advindos de cruzamento de dados do chão de fábrica, principalmente para auxiliar na tomada de decisões gerenciais.

Muitos processos que antes eram controlados manualmente passaram a ser executados automaticamente e espera-se que em um futuro o nível de controle de cada variável em relação aos procedimentos atuais para redução de custos, passe a ser da ordem individual, isto é, para cada máquina produtiva.

As economias esperadas estão relacionadas à melhoria de desempenho de produtividade. A redução de desperdício ou refugo também é minuciosamente monitorada pelo MES, por meio de sensores de entrada e saída de equipamentos individuais.

Os tempos de setup são memorizados no banco de dados para análises posteriores, comparando turnos com melhor desempenho, os tempos médios, entre outros. Já a capacidade produtiva não foi alterada em função do MES, mas espera-se que o sistema auxilie na utilização de todo o potencial produtivo instalado.

Dentre as iniciativas mais impactantes para a redução de custos, destaca-se a possibilidade de identificar equipamentos unitários que estejam com índice de refugo em tendência ascendente o que possibilita intervenções localizadas, as quais reduzem o desperdício. Ademais, atuar em equipamentos que estão com tendência decrescente de eficiência auxilia na melhoria da produtividade. 
Na planta aonde há o MES, devido ao pouco tempo de instalação, ainda não pode ser mensurada uma redução significativa nos custos, mas houve uma melhora apreciável nos controles existentes e na qualidade dos relatórios gerados.

As medidas utilizadas para redução de custo nos últimos 03 (três) anos se relacionam a redução no consumo de insumos através da otimização de processos, redução de desperdício, redução no descarte por meio de intervenções de manutenção nos equipamentos e conscientização dos colaboradores.

A visão dos gestores em relação ao conceito de integração de sistemas visando à redução de custos é que a integração é grande valia na redução de custos porque permite ao gestor enxergar de forma mais abrangente distintas áreas da empresa, principalmente as áreas interdepartamentais.

Os principais fatores considerados na redução de custos são elencados a seguir, assim como o grau de importância na contribuição para reduzir custos e os impactos gerados nas operações de cada um deles. O nível de detalhamento de cada variável de controle em relação aos procedimentos atuais de redução de custos deve contemplar os equipamentos produtivos em níveis individuais.

\section{Fator 01: Melhoria na Produtividade}

Impacto: Alto

Detalhes: Em relação ao fator produtividade, entende-se que a entrada do sistema MES pode contribuir para que seja possível fabricar mais unidades de produtos acabados utilizando ou consumindo a mesma quantidade de recursos e matéria-prima. Este aumento de produtividade decorre da redução de desperdícios que podem ser solucionados por meio do MES.

\section{$\checkmark$ Fator 02: Redução do Descarte}

Impacto: Alto

Detalhes: O fator redução do descarte foi possível através do MES devido à possibilidade de detecção de problemas e uma atuação mais rápida sobre os equipamentos com baixo desempenho de qualidade. Em mescla com os dados oferecidos pelo MES, os gestores 
podem obter informações de máquinas de forma rápida e organizada para a tomada de decisões.

\section{Fator 03: Lacunas Preenchidas}

Impacto: Alto

Detalhes: As lacunas que poderiam ser preenchidas com a integração de sistemas estão situadas entre as medições físicas (Kg, Litros, Tempo) e monetárias/financeiras (Custos em $\mathrm{R} \$)$.

Mesmo após as iniciativas de implantar o MES, a empresa está sempre buscando opções de avanço tecnológico para aumentar a competitividade. Assim, após os investimentos com o MES, a empresa percebeu que poderia investir em outras opções para compensar a alimentação manual de dados, através dos equipamentos de medição automáticos, novos sistemas de controle estatístico do processo, softwares de gestão e controle. Todas estas opções estão dentro das possibilidades de investimento, tendo como premissa o retorno financeiro esperado.

Após analisar os casos, foi desenvolvido o Quadro 5, resumindo os principais achados dentro de cada caso, verificando os impactos gerados pelo sistema, a caracterização da implementação do MES e o resultado gerado sobre a redução de custos. 
Quadro 5 - Resumo geral da implementação do MES

\begin{tabular}{|c|c|c|c|}
\hline & CASO A & CASO B & CASO C \\
\hline $\begin{array}{l}\text { Estrutura } \\
\text { Organizacional }\end{array}$ & $\begin{array}{l}\text { Duas unidades de negócios com } \\
\text { estratégias de manufatura } \\
\text { distintas, sendo a primeira } \\
\text { orientada para a contínua e a } \\
\text { segunda para a discreta }\end{array}$ & $\begin{array}{l}\text { Unidade de negócios atuante no } \\
\text { mercado brasileiro, com foco } \\
\text { em manufatura discreta. A } \\
\text { empresa também exerce } \\
\text { atividades de exportação }\end{array}$ & $\begin{array}{l}\text { Unidades de negócios } \\
\text { posicionadas no Brasil, com } \\
\text { Diretoria Industrial atuando em } \\
\text { diversas frentes }\end{array}$ \\
\hline Impactos & $\begin{array}{l}\text { - Remodelagem de processos } \\
\text { - Questionar a cadeia produtiva } \\
\text { - Extinguir controles antigos, } \\
\text { dentre os que se provaram sem } \\
\text { efeito } \\
\text { - A organização admite uma } \\
\text { postura mais crítica sobre suas } \\
\text { necessidades }\end{array}$ & $\begin{array}{l}\text { - Elevação do conhecimento de } \\
\text { processo fabril e na formação } \\
\text { de preços } \\
\text { - Aumento da integração } \\
\text { operário x liderança }\end{array}$ & $\begin{array}{l}\text { - Inovações geradas e } \\
\text { percebidas principalmente no } \\
\text { chão-de-fábrica; } \\
\text { - Os impactos estão sendo } \\
\text { avaliados, devido ao } \\
\text { momento de implementação } \\
\text { em que o MES se encontra. }\end{array}$ \\
\hline $\begin{array}{l}\text { Caracterização } \\
\text { do MES }\end{array}$ & $\begin{array}{l}\text { - Aprimoramento no } \\
\text { processamento de informações } \\
\text { e das consolidações diárias } \\
\text { - Consolidações tornaram-se } \\
\text { mais rápidas, em virtude de } \\
\text { menos digitações manuais } \\
\text { - Monitoramento qualitativo e } \\
\text { quantitativo dos processos } \\
\text { industriais } \\
\text { - Por meio da integração com o } \\
\text { ERP, existe a baixa de ordens } \\
\text { de processo para que se } \\
\text { determine o exato lote de cada } \\
\text { ordem } \\
\text { - Informações sobre os produtos } \\
\text { intermediários dentro do } \\
\text { processo por batelada } \\
\text { - Atualmente, o MES não retorna } \\
\text { ao ERP os tempos reais de } \\
\text { execução dos processos }\end{array}$ & $\begin{array}{l}\text { - Coleta de dados via código } \\
\text { de barra, com pontos de } \\
\text { coleta próximos aos operários } \\
\text { - Acesso aos relatórios para } \\
\text { toda a supervisão e níveis } \\
\text { hierárquicos superiores via } \\
\text { intranet } \\
\text { - Customização do produto e } \\
\text { vários pontos do processo: } \\
\text { o Tarefas onde o custo do } \\
\text { apontamento seria } \\
\text { superior ao custo da } \\
\text { operação (pequenas } \\
\text { operações) } \\
\text { o Apontamento em lotes } \\
\text { (tratamentos térmicos) } \\
\text { - Relatórios em tempo real } \\
\text { - Ausência da implantação do } \\
\text { pacote de OEE }\end{array}$ & $\begin{array}{l}\text { - Processo de implementação } \\
\text { do MES ainda em } \\
\text { consolidação } \\
\text { - Não há evidência de } \\
\text { integração entre o ERP e o } \\
\text { MES, mas há pretensão de } \\
\text { realizá-la no futuro } \\
\text { - Ferramenta sofisticada de } \\
\text { monitoramento de parâmetros } \\
\text { de processo; } \\
\text { - Utilizado para medir: } \\
\text { o Desempenho de } \\
\text { equipamentos } \\
\text { o Tempo de parada } \\
\text { o Tempo médio entre } \\
\text { paradas } \\
\text { - Algumas informações ainda } \\
\text { são manualmente alimentadas } \\
\text { em planilhas }\end{array}$ \\
\hline $\begin{array}{l}\text { Redução de } \\
\text { Custos }\end{array}$ & $\begin{array}{l}\text { o Resultados superaram as } \\
\text { expectativas } \\
\text { ○ Dificuldade em equacionar o } \\
\text { legado do projeto de forma } \\
\text { quantitativa } \\
\text { O MES e integração com ERP } \\
\text { contribuem para a redução de } \\
\text { custos, porém há uma } \\
\text { necessidade de se quantificar e } \\
\text { mensurar esta redução }\end{array}$ & $\begin{array}{l}\text { o Grande expectativa, } \\
\text { aguardando finalização da } \\
\text { segunda fase, para avaliar a } \\
\text { superação das expectativas } \\
\text { em torno dos investimentos } \\
\text { o Contribui muito para uso de } \\
\text { melhorias e reduções de } \\
\text { custos. Muito útil na geração } \\
\text { de informações, que por sua } \\
\text { vez, oferecem um maior } \\
\text { número de opções para } \\
\text { tomada de decisões }\end{array}$ & $\begin{array}{l}\text { o Acredita-se que futuramente } \\
\text { muitos benefícios em termos } \\
\text { de redução possam ser } \\
\text { rendidos. } \\
\text { o Expectativas em relação à } \\
\text { geração de relatórios } \\
\text { advindos de cruzamento de } \\
\text { dados para auxiliar na tomada } \\
\text { de decisões gerenciais. } \\
\text { O Produtividade, menor } \\
\text { desperdício, e lacunas } \\
\text { preenchidas }\end{array}$ \\
\hline
\end{tabular}

FONTE: Quadro elaborado pelo próprio autor da obra, portanto, sem fonte indicada. 


\subsection{Análise dos Casos}

Iniciando as análises dos resultados obtidos, a primeira perspectiva analisada é em relação ao estágio de maturidade em que a implantação do MES se encontra entre as organizações.

Nos Quadros 6, 7 e 8 foram agrupados os dados, conforme as respostas de cada caso. Após analisar os grupos, identificou-se que na maioria dos casos, os respondentes apontam para vários benefícios percebidos, tais como disponibilização de dados em tempo real, coleta automática de dados, aumento de produtividade e redução de desperdícios.

Os dados da tabela demonstram que em algumas situações, houve a pontuação simultânea ou o compartilhamento de características do MES em todos os casos, tanto para os atributos quanto para os obstáculos. Porém, para alguns pontos específicos, os pontos levantados foram peculiares de cada caso. Por exemplo, em todos os casos, foi revelado que houve um aumento da produtividade, mas que também era necessário um grande envolvimento das equipes como obstáculo na implementação. Contudo, em apenas dois casos foi notificada uma maior resistência a mudança nos processos.

Tal situação pode ter ocorrido em decorrência do tipo da empresa, da diversidade da gestão ou até mesmo do tempo decorrido da implantação do MES. Tantos os atributos como os obstáculos mencionados na pesquisa foram citados espontaneamente pelos entrevistados, sem qualquer tipo de viés

\section{Principais Atributos Detectados no Uso do MES}

Quadro 6 - Principais atributos detectados no uso do MES

\begin{tabular}{llll}
\hline & CASO A & CASO B CASO C \\
\hline Informações atualizadas em tempo real & $\mathbf{X}$ & $\mathbf{X}$ & $\mathbf{X}$ \\
\hline Maior facilidade para emissão de relatórios & $\mathbf{X}$ & $\mathbf{X}$ & $\mathbf{X}$ \\
\hline Coleta automática de dados & $\mathbf{X}$ & $\mathbf{X}$ & $\mathbf{X}$ \\
\hline Aumento de produtividade & $\mathbf{X}$ & $\mathbf{X}$ & $\mathbf{X}$ \\
\hline Redução de desperdícios e perdas & $\mathbf{X}$ & $\mathbf{X}$ & $\mathbf{X}$ \\
\hline
\end{tabular}




\begin{tabular}{|c|c|c|c|}
\hline Redução de setup & $\mathbf{X}$ & $\mathbf{X}$ & $\mathbf{X}$ \\
\hline Maior visibilidade dos problemas detectados nas fábricas & $\mathbf{X}$ & $\mathbf{X}$ & \\
\hline Maior controle sobre os parâmetros do processo & $\mathbf{X}$ & & $\mathbf{X}$ \\
\hline Mensuração do desempenho de equipamentos, OEE e rendimento & $\mathbf{X}$ & & $\mathbf{X}$ \\
\hline Tempo de parada e tempo médio entre paradas & $\mathbf{X}$ & & $\mathbf{X}$ \\
\hline Melhoria no planejamento da produção & & $\mathbf{X}$ & \\
\hline Menor erro de dados inseridos manualmente & $\mathbf{X}$ & & \\
\hline Desoneração das funções dos operadores & $\mathbf{X}$ & & \\
\hline $\begin{array}{l}\text { Centralização das informações por meio de um repositório único e } \\
\text { acessível a todos }\end{array}$ & $\mathbf{X}$ & & \\
\hline Projetos de melhoria de produtividade & & $\mathbf{X}$ & \\
\hline Melhoria no controle de processo por meio de análises estatísticas & & & $\mathbf{X}$ \\
\hline Monitorar processos no nível de detalhes por equipamento & $\mathbf{X}$ & & \\
\hline Processamento de informações e das consolidações diárias & $\mathbf{X}$ & & \\
\hline $\begin{array}{l}\text { Possibilidade de obter sobre o processo produtivo dos produtos } \\
\text { intermediários ou semi-acabados }\end{array}$ & $\mathbf{X}$ & & \\
\hline Rastreabilidade e lead-times entre os processos intermediários & $\mathbf{X}$ & & \\
\hline \multicolumn{4}{|l|}{ Análise dos dados e informações de todos os processos da cadeia } \\
\hline Sistema customizável, permitindo várias possibilidades; & $\mathbf{X}$ & & \\
\hline $\begin{array}{l}\text { Aumento da visibilidade, confiabilidade e centralização das } \\
\text { informações }\end{array}$ & $\mathbf{X}$ & & \\
\hline Agilização de processos & $\mathbf{X}$ & & \\
\hline Custeio dos produtos & $\mathbf{X}$ & & \\
\hline Gestão efetiva da manufatura e evolução das OP & & $\mathbf{X}$ & \\
\hline $\begin{array}{l}\text { Planejamento produtivo com qualidade, ciência dos tempos reais de } \\
\text { cada grupo de tarefas. }\end{array}$ & & $\mathbf{X}$ & \\
\hline
\end{tabular}

FONTE: Quadro elaborado pelo próprio autor da obra, portanto, sem fonte indicada.

Os resultados relacionados aos obstáculos no uso do MES exprimem uma necessidade de integração entre os membros, pois os entrevistados acreditam que foi requerido um engajamento de todas as equipes envolvidas, e perceberam a necessidade contínua do 
alinhamento de expectativas. Como melhoria, sugeriam que houvesse ações para contornar a forte resistência frente às mudanças.

Assim constata-se que da mesma forma, muitos dos obstáculos citados na literatura também foram evidenciados na prática.

\section{Principais Obstáculos Detectados no Uso do MES}

Quadro 7 - Principais obstáculos detectados no uso do MES

\begin{tabular}{lccc}
\hline & CASO A & CASO B & CASO C \\
\hline $\begin{array}{l}\text { Necessário maior envolvimento das equipes participantes do } \\
\text { projeto }\end{array}$ & $\mathbf{X}$ & $\mathbf{X}$ & $\mathbf{X}$ \\
\hline $\begin{array}{l}\text { Alinhamento de expectativas } \\
\text { Abertura demasiada para customização }\end{array}$ & $\mathbf{X}$ & $\mathbf{X}$ & $\mathbf{X}$ \\
\hline $\begin{array}{l}\text { Necessidade de disponibilizar mais recursos junto à equipe } \\
\text { de operação }\end{array}$ & $\mathbf{X}$ & $\mathbf{X}$ & $\mathbf{X}$ \\
\hline $\begin{array}{l}\text { Envolvimento da engenharia, equipe de projetos e gerência } \\
\text { de fábrica nos levantamentos de requisitos }\end{array}$ & $\mathbf{X}$ & $\mathbf{X}$ & $\mathbf{X}$ \\
\hline $\begin{array}{l}\text { Forte resistência à mudança } \\
\text { Disseminação do conhecimento e processos }\end{array}$ & $\mathbf{X}$ & $\mathbf{X}$ & $\mathbf{X}$ \\
\hline \begin{tabular}{l} 
Mudança de atividades prévias desempenhadas \\
\hline
\end{tabular} & $\mathbf{X}$ & \\
\hline
\end{tabular}

FONTE: Quadro elaborado pelo próprio autor da obra, portanto, sem fonte indicada.

Quando discorridos os principais problemas associados ao uso do MES, foram reconhecidas em todos os casos a possibilidade de customizações. Algumas passagens apontam para questões como o suporte ao sistema. 


\section{Principais Problemas Detectados no Uso do MES}

Quadro 8 - Principais problemas detectados no uso do MES

\section{CASO A CASO B CASO C}

\begin{tabular}{lll}
\hline Risco de descontinuidade do software de MES adquirido & $\mathbf{X}$ \\
\hline Risco de falta de suporte adequado & $\mathbf{X}$ & \\
\hline No caso de muitas necessidades não há solução standard & $\mathbf{X}$ & $\mathbf{X}$ \\
\hline Existe o risco de se caminhar muito no sentido de customizações & $\mathbf{X}$ & $\mathbf{X}$ \\
\hline
\end{tabular}

FONTE: Quadro elaborado pelo próprio autor da obra, portanto, sem fonte indicada.

\section{Principais Impactos Gerados no Uso do MES}

O Quadro 9 evidencia os principais impactos causados pelo uso do MES nos 03 casos.

\section{Quadro 9 - Impactos no uso do MES}

Casos

Caso A

Caso B

Caso C
Impactos Gerados

O MES mobilizou os recursos para que houvesse a oportunidade de haver uma remodelagem de processos sobre as operações existentes, com isso possibilitando aumentar o valor agregado na cadeia como um todo.

Após o uso do MES, identificou-se que foi desenvolvido um aumento no conhecimento do processo fabril, de tal forma que forma que com um controle maior, fosse possível reunir recursos mais adequados para calcular o preço de venda dos produtos.

Já é perceptível que a entrada do MES pode fornecer os subsídios necessários para executar mudanças relevantes e ações diretas no chão-de-fábrica, modificando alguns processos e operações executados atualmente.

FONTE: Quadro elaborado pelo próprio autor da obra, portanto, sem fonte indicada.

Ao analisar os dados dos principais impactos do MES, os resultados claramente mostram que foram alcançados objetivos diferentes pelo MES. 
A conclusão que se pode obter com este estudo, é que de fato o MES parece ter contribuído ou apresenta o potencial para oferecer as ferramentas adequadas para a redução de custos em organizações de manufatura discreta.

Todavia, seria necessário um estudo mais aprofundado para averiguar quais os objetivos das empresas mais impactados pelo MES e também se a integração com o ERP de fato causaria alguns impactos nestes objetivos. Para tal, seria preciso uma massa de dados mais extensa, para que pudesse haver uma amostra mais abrangente e que pudesse oferecer condições de cálculo quantitativo para entender exatamente em quais pontos o MES causa impactos nas empresas.

\section{Quadro 10 - Resumo das conclusões}

\section{OPERACIONAL}

- Os controles desenvolvidos anteriormente foram extintos, pois se provaram sem efeito;

- A corporação decidiu investir para obter uma melhoria no prazo de entrega de seu produto.

\section{PROCESSOS}

- A organização admite uma postura mais crítica sobre o que é ou não necessário;

- Essa iniciativa permitiu que a empresa percebesse a necessidade de se medir a execução dos trabalhos de manufatura para poder obter a qualidade no planejamento;

- Assim houve a decisão de adquirir uma solução que pudesse atender a estes requisitos em conjunto com as soluções já existentes.

\section{SOLUÇÕES}

- Motivaram a busca por novas soluções de sistemas, tais como o nível baixo de atendimento ao cliente no prazo;

- Elevado valor de inventário em processo;

- Além de comprometer as tomadas de decisão por falta de visibilidade na manufatura.

FONTE: Quadro elaborado pelo próprio autor da obra, portanto, sem fonte indicada. 


\section{$\underline{\text { Reducão de Custos com o MES }}$}

A Figura 18 apresenta um resumo específico referente à redução de custos, após implementação do MES nos 03 casos apresentados, de acordo com a fase de implementação e suas peculiaridades.

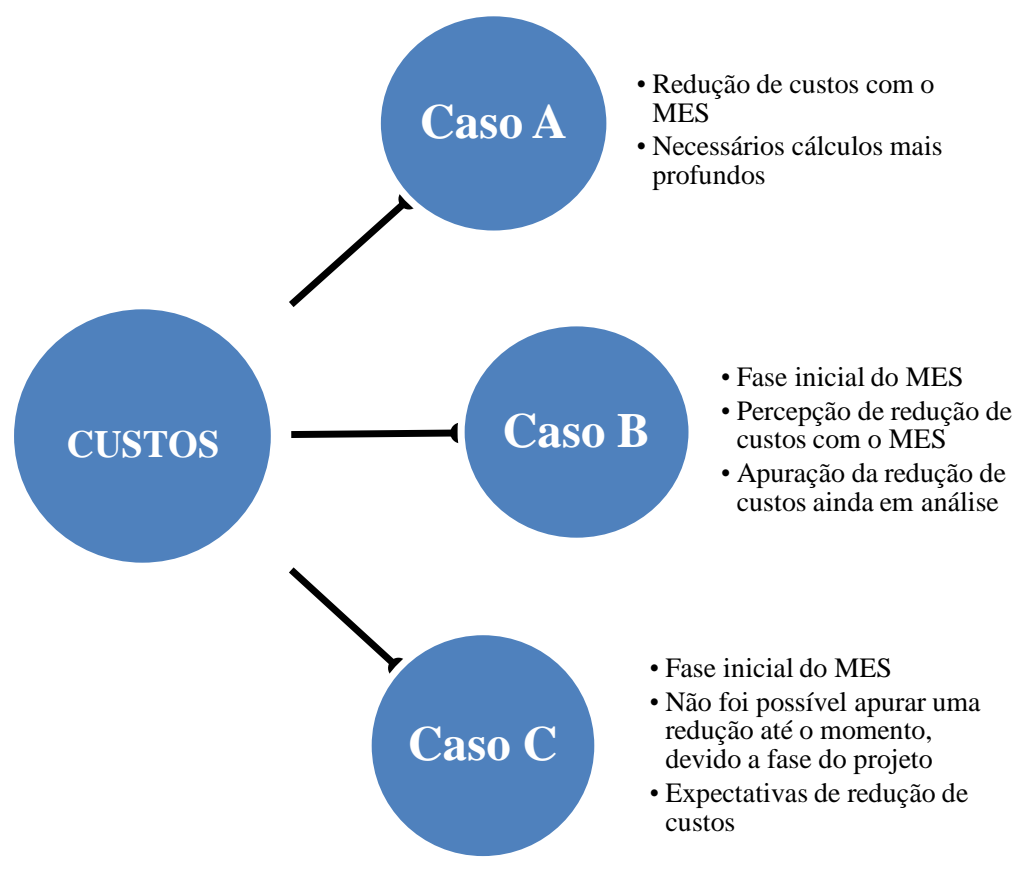

Figura 18 - Redução de custos

FONTE: Figura elaborada pelo autor da obra.

Pelos dados encontrados, pode-se notar diferentes perspectivas da redução de custos para cada caso. Ao comparar os resultados no que tange a possibilidades de redução foram comentados os seguintes aspectos:

i. [TODOS OS CASOS] Houve uma melhoria notável no controle;

ii. [CASO B] Houve redução de custo, principalmente no que diz respeito à identificação de fatores que geram desperdícios;

iii. [CASO C] Não houve aumento da capacidade produtiva;

iv. [CASO C] Identificação de equipamentos com índice de refugo em tendência ascendente, eficiência auxilia na melhoria da produtividade; 
v. [CASOS A e B] Os resultados advindos do MES dependem também da maturidade de processos e tarefas que a instituição apresenta para que esforços sejam convertidos em ganhos de capital, propriamente ditos.

O tema da redução de custos pode recair sobre a questão de se dimensionar e definir o que realmente originou a redução de custos, antes e após o MES.

Portanto, se faz preciso ter uma visão clara de como viabilizar a coleta automática de dados, e de estruturar o banco de dados que irá armazenar todas as informações absorvidas do chão-de-fábrica.

Contudo, a questão é o que fazer com estes dados e como melhorar a gestão por meio de ações, sejam estas de alta ou de baixa complexidade, caminhando em direção à redução dos custos de produção.

Em contrapartida, o MES parece oferecer inúmeras funcionalidades positivas para a gestão da manufatura, porém é preciso utilizar todos os recursos em conjunto com uma gestão efetiva e forte acompanhamento de atividades e medição de desempenho. Se não houver ação pode-se correr o risco do sistema se tornar apenas um repositório de dados.

É preciso a alocação de uma equipe dedicada para efetuar cálculos comparativos antes e pós MES, até mesmo para entender o que foi o que o MES gerou de fato de benefício, e o que foi atividade indireta e paralela ao MES. Identificou-se que o MES gera os benefícios esperados, mas que ainda não foram totalmente contabilizados. Tais constatações induzem a concluir que o MES reduz os custos, assim como os índices de refugo e setup. Neste caso, seria preciso investigar mais profundamente sob a óptica do gerenciamento de custos em detrimentos da manufatura, propriamente dita. 


\section{DISCUSSÃO DOS RESULTADOS}

Pela análise dos 03 casos averiguados, percebe-se que os diferentes estágios do uso do MES proporcionam diferentes visões, dentro do curto, médio e longo prazo. Conforme visto no Quadro 11, pode-se entender que inclusive a integração com o ERP parece ser um elemento mutável ao longo da implantação do MES e de bastante relevância para verificar os impactos financeiros, integrados com as demais áreas da empresa.

Com o tempo, os dados coletados pelo MES podem, se devidamente utilizados, gerar novas visões para a tomada de ações no médio e longo prazo, advindo de ações efetivas sobre problemas identificados pelo sistema.

Quadro 11 - Resumo do MES

\begin{tabular}{|c|l|l|}
\hline Perspectiva & \multicolumn{1}{|c|}{ Curto Prazo } & \multicolumn{1}{c|}{ Médio e Longo Prazo } \\
\hline $\begin{array}{c}\text { REDUÇÃO DE } \\
\text { CUSTOS }\end{array}$ & $\begin{array}{l}\text { MES oferece os principais } \\
\text { requisitos para redução de custos e } \\
\text { permite a visibilidade de dados } \\
\text { para tomada de ação. }\end{array}$ & $\begin{array}{l}\text { Com as tomadas de ações sobre as } \\
\text { informações adquiridas pelo MES, } \\
\text { as organizações podem obter } \\
\text { reduções expressivas de custos, por } \\
\text { meio de técnicas de mensuração } \\
\text { mais apuradas, comparando os } \\
\text { dados antigos com aqueles } \\
\text { detectados após a instalação do } \\
\text { MES. }\end{array}$ \\
\hline INTEGRAÇÃO & $\begin{array}{l}\text { No curto prazo a integração com o } \\
\text { ERP não parece ser um requisito } \\
\text { obrigatório para obter reduções de } \\
\text { custos. }\end{array}$ & $\begin{array}{l}\text { Contudo, no médio e no longo prazo } \\
\text { a integração parece ser bastante } \\
\text { efetiva no sentido de retornar } \\
\text { informações financeiras e atualizar } \\
\text { os demais processos que estão } \\
\text { envolvidos no ERP, tais como } \\
\text { Compras, Vendas, Inventário e } \\
\text { Gestão/Fechamento de Estoque, } \\
\text { MRP e Fiscal. }\end{array}$ \\
\hline
\end{tabular}




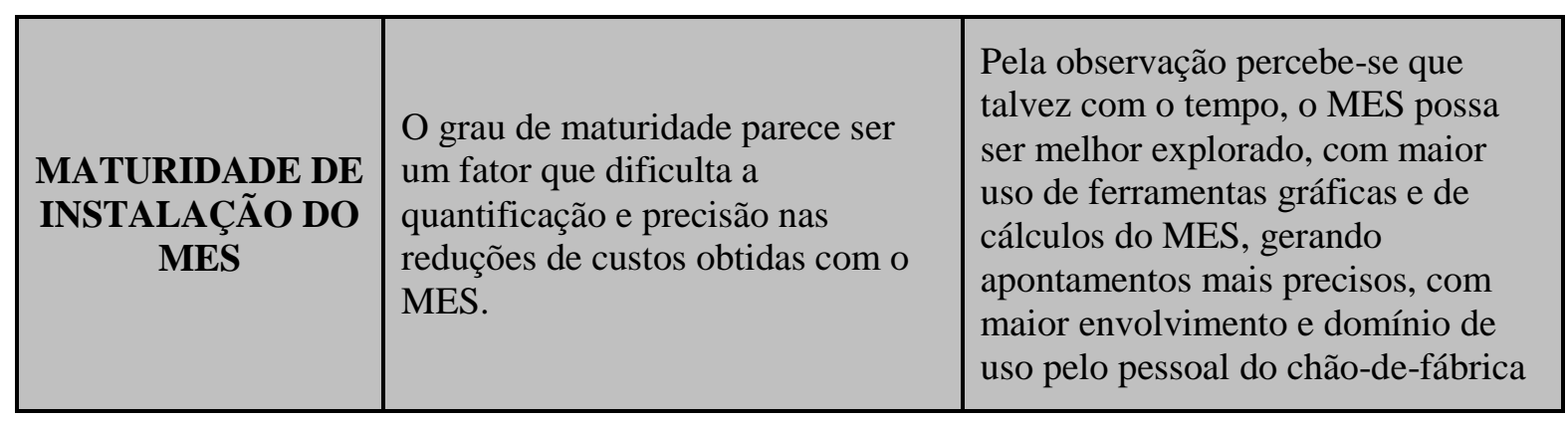

FONTE: Quadro elaborado pelo próprio autor da obra, portanto, sem fonte indicada.

Para facilitar a visualização dos resultados e comentários deste estudo, foram agrupados os dados de acordo com as proposições e os dados informados no instrumento de coleta, na seguinte ordem:

Quadro 12 - Agrupamento de dados por proposição

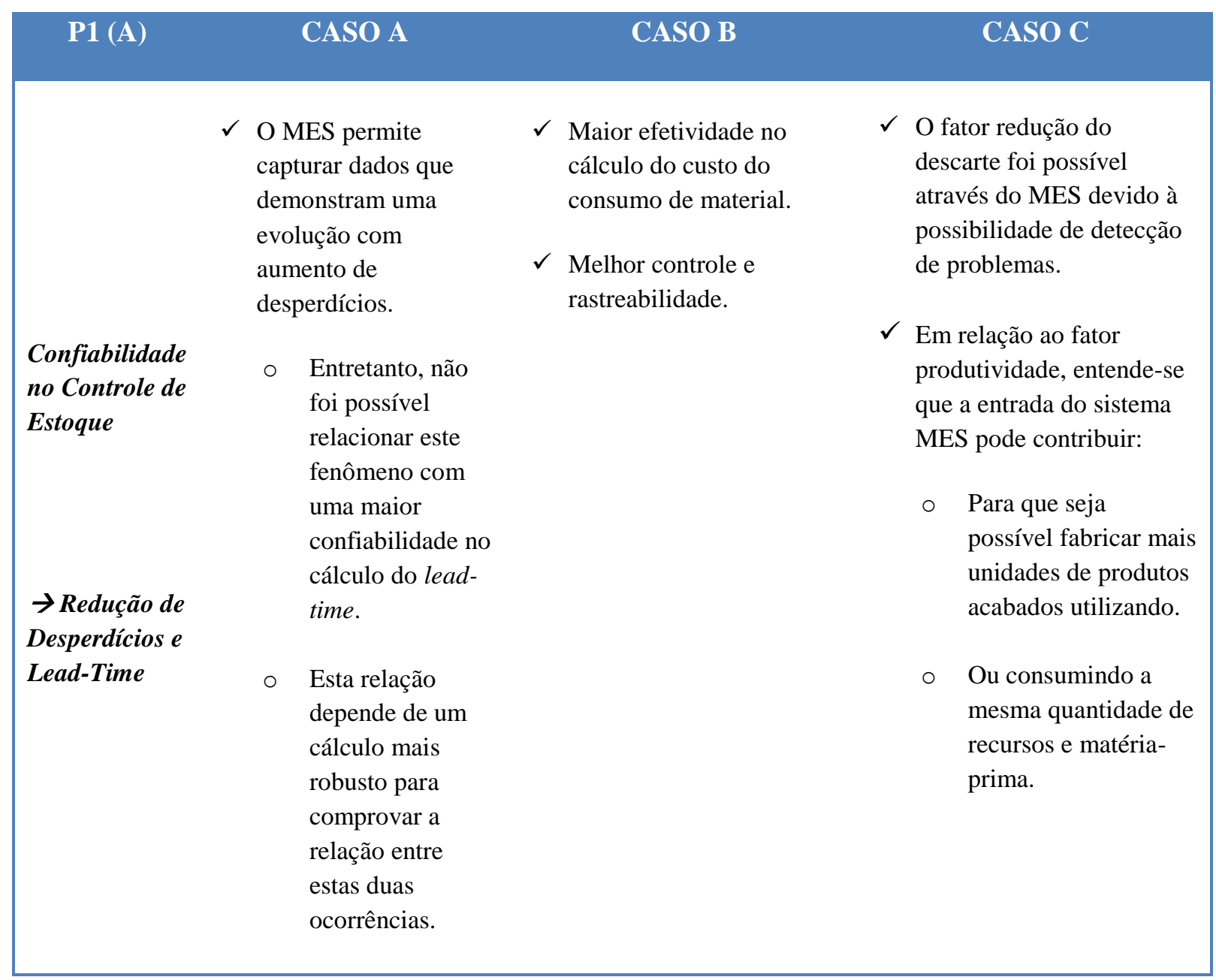




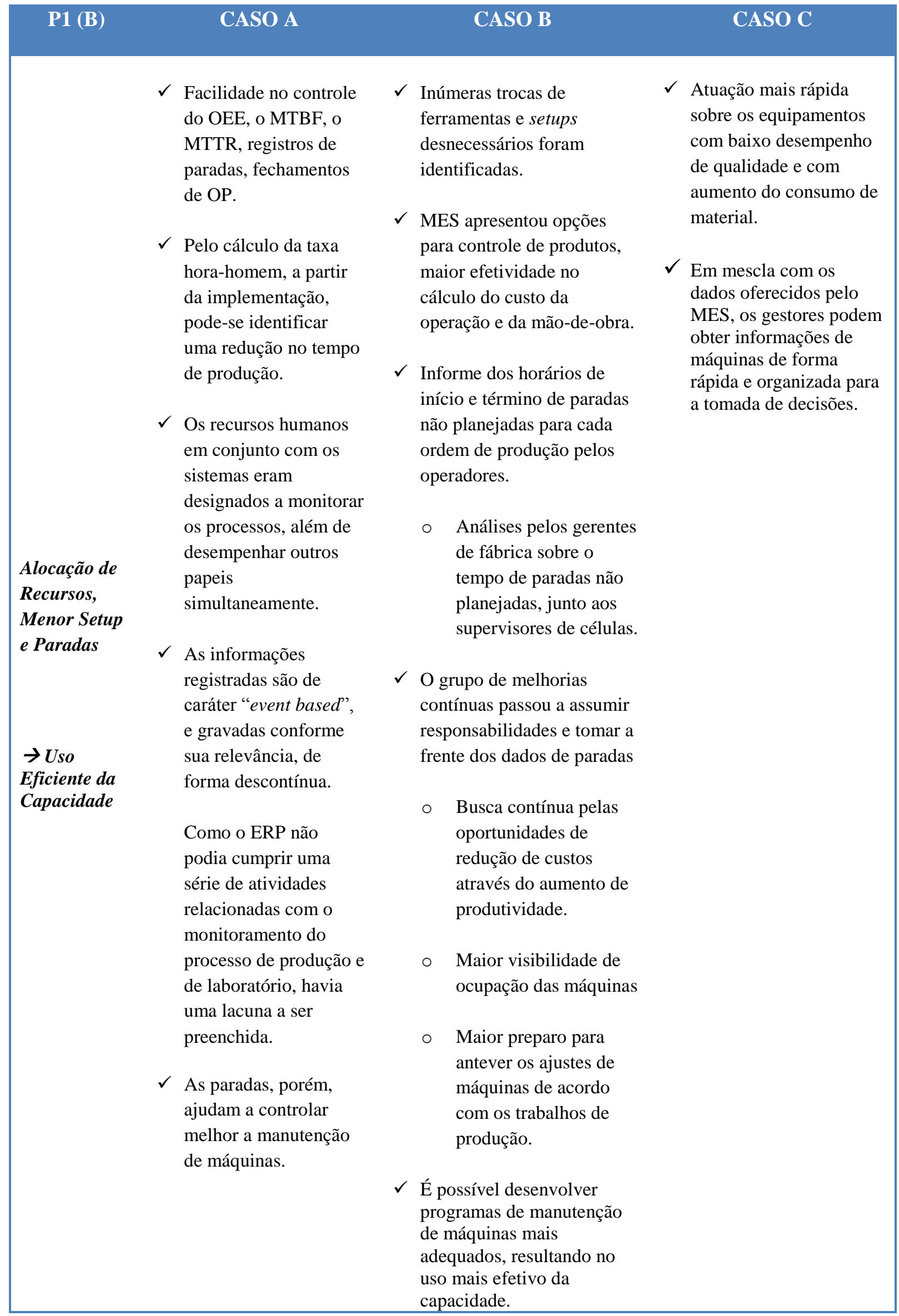




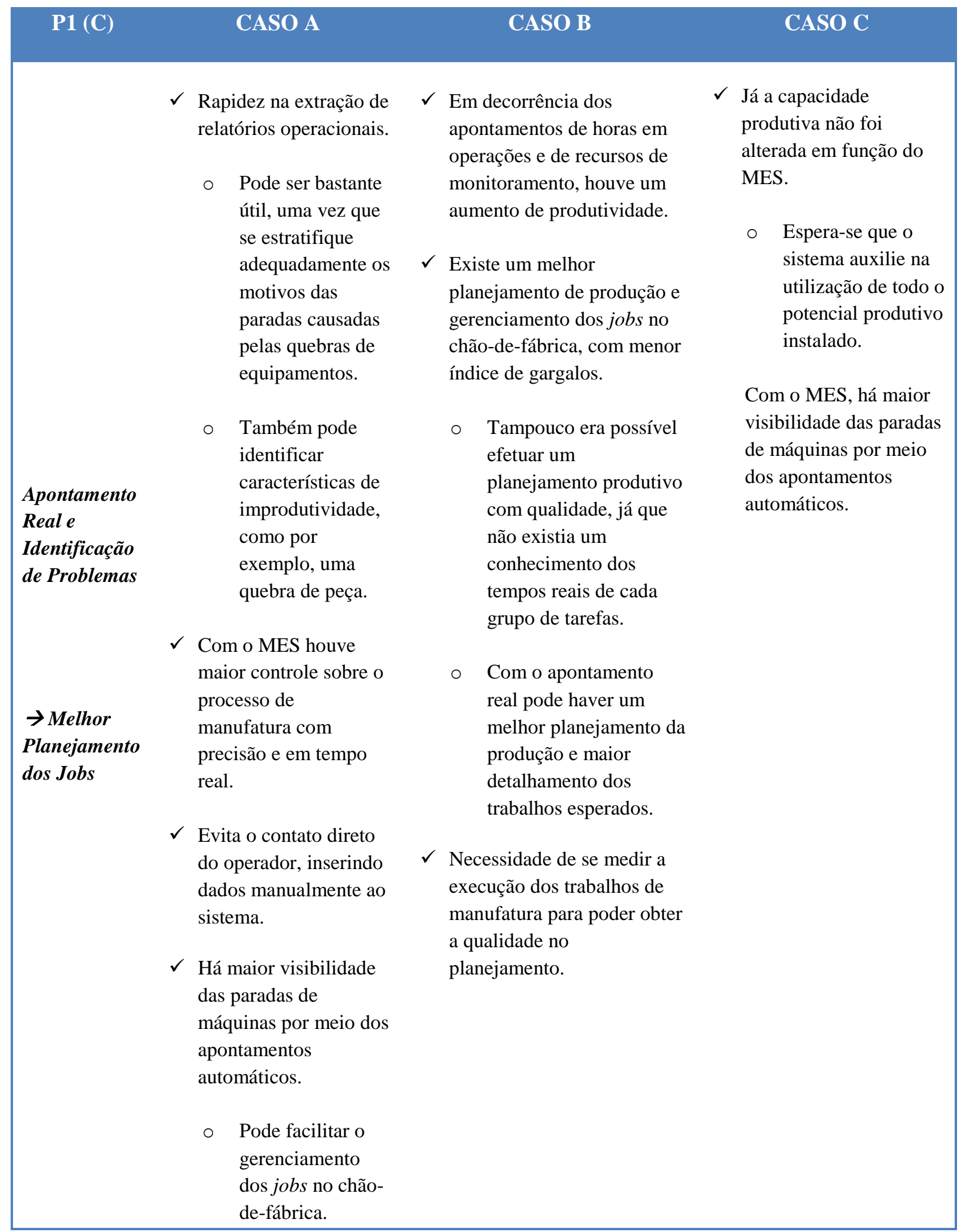

\section{P2} CASO A CASO B

CASO C

\section{Mudança}

de

Processos $\checkmark$ A proposição P2

parece ser bastante
Da mesma forma no Caso

$\mathrm{B}$, percebe-se que a
As mudanças podem ocorrer a partir de ações específicas em cada área. 


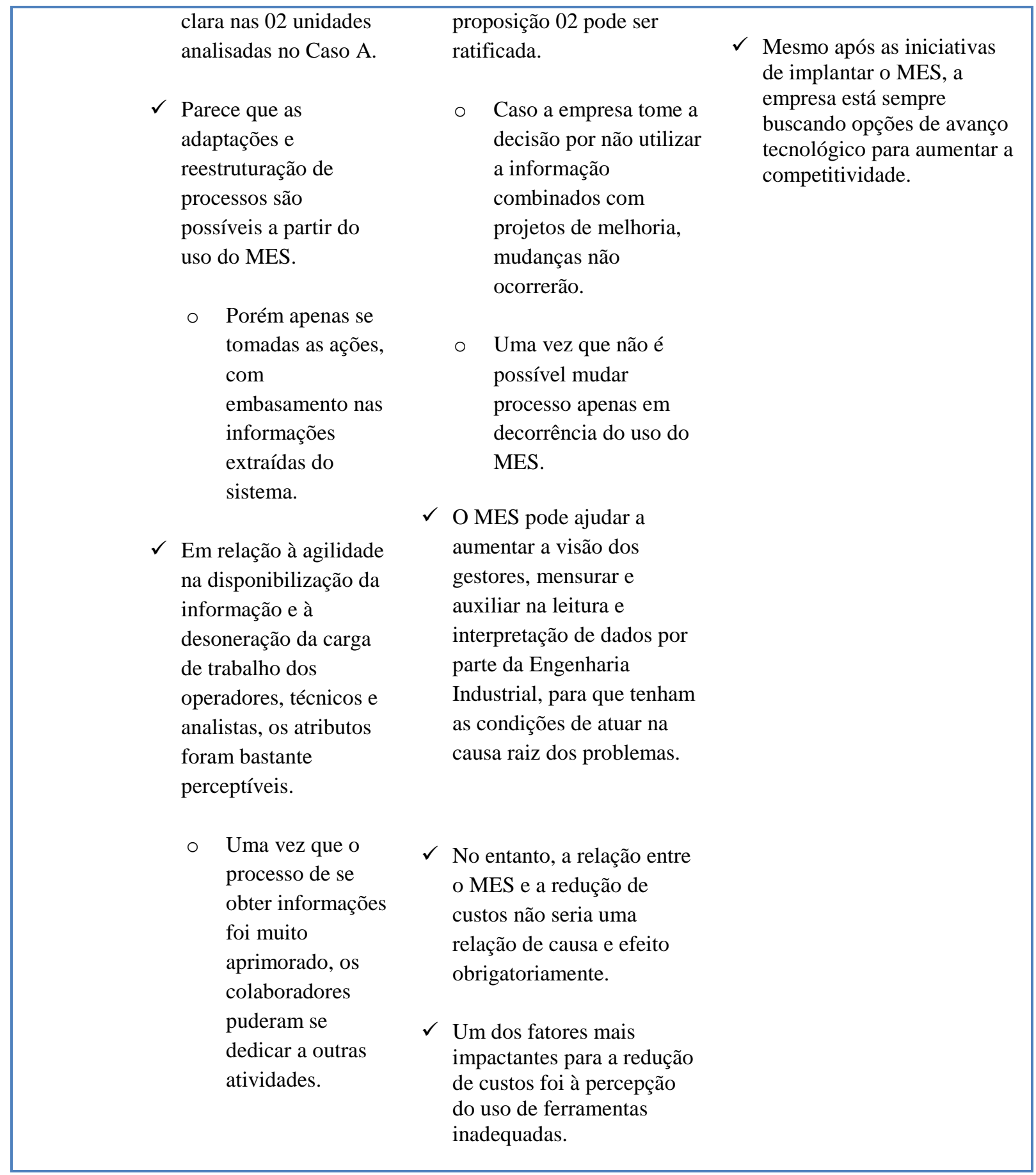

FONTE: Quadro elaborado pelo próprio autor da obra, portanto, sem fonte indicada.

Em adição, comparando as diversas tecnologias disponibilizadas no mercado, como os sistemas e o controle atual das empresas (por exemplo, via planilhas), isto é, como os custos são controlados atualmente, em contraposição com os métodos desejados para serem utilizados efetivamente (por exemplo, via sistema MES), ou seja, como os custos poderiam ser controlados. 
Sobretudo, o projeto discute sobre os níveis de detalhamento em que as empresas se encontram, até onde estão com os sistemas ERP, e até onde podem chegar, com o desenvolvimento de novos softwares.

Quadro 13 - Comparativos pós-instalação do MES

\begin{tabular}{|c|c|}
\hline \multirow{4}{*}{$\begin{array}{l}\text { Controle sem } \\
\text { MES }\end{array}$} & Planilhas ou papel físico \\
\hline & Apontamentos manuais \\
\hline & Documentações externas \\
\hline & Sistemas de informação \\
\hline \multirow{4}{*}{$\begin{array}{l}\text { Lacunas } \\
\text { Existentes }\end{array}$} & Controle de horas paradas \\
\hline & Dificuldade de apontamento \\
\hline & Gerenciamento da matéria-prima \\
\hline & Gastos desconhecidos, retrabalho \\
\hline \multirow{4}{*}{$\begin{array}{l}\text { Controle com } \\
\text { MES }\end{array}$} & Apontamento automático \\
\hline & Informações mais precisas \\
\hline & Acesso a banco de dados \\
\hline & Automatização da coleta de dados e consolidações \\
\hline
\end{tabular}

FONTE: Quadro elaborado pelo próprio autor da obra, portanto, sem fonte indicada.

Sob outro ponto de vista pode ser interessante averiguar o grau de impacto em termos da própria operação como em termos financeiros causados na melhoria da redução de custos, de acordo com cada variável no controle de custos e a integração entre os sistemas legados.

De um modo genérico podem ser analisados apenas alguns fatores, como por exemplo, os 05 fatores citados no Quadro 14, elencando os principais fatores mencionados que exprimem aqueles mais citados durante a análise de resultados. Em estudos futuros, a gama destes fatores pode ser ampliada. 
Quadro 14 - Grau de impactos causados

Alto Impacto Médio Impacto Baixo Impacto

\begin{tabular}{|c|c|c|c|}
\hline \multirow{7}{*}{$\begin{array}{l}\text { Material (M) } \\
\text { Setup (S) } \\
\text { Desperdícios (D) } \\
\text { Informações (I) } \\
\text { Paradas (P) } \\
\text { Layout (L) } \\
\text { Compliance (C) }\end{array}$} & X & & \\
\hline & & $X$ & \\
\hline & X & & \\
\hline & & $X$ & \\
\hline & $X$ & & \\
\hline & & & $X$ \\
\hline & & & $X$ \\
\hline
\end{tabular}

FONTE: Quadro elaborado pelo próprio autor da obra, portanto, sem fonte indicada.

Outra opção pode ser o desenvolvimento de uma tabela comparativa para avaliar o grau de importância atribuído a cada aspecto do controle de custos para uma determinada indústria. Este quadro poderia ser tabulado, após preenchimento do questionário distribuído entre os gestores, representando os graus de impactos elevados, médios ou moderados.

Na realidade, este quadro seria uma proposta de análise futura com dados quantitativos procurando exprimir com mais detalhes o percentual da participação de redução de custos para cada fator de alto impacto mencionado no Quadro 14, cruzando os percentuais com os graus de impactos para geração de curva $\mathrm{ABC}$.

Outra perspectiva de análise consiste em segmentar as variáveis identificadas de acordo com as reduções de custos obtidas em relação ao seu impacto. Em algumas situações, podem ser despendidos esforços em variáveis que, segundo a análise dos resultados restritos a esta pesquisa, podem causar uma redução de custos menos intensa. Assim, pode-se distribuir os esforços em ações que reduzam os custos em fatores impactantes e que possuam alto potencial de redução de custos.

\section{Pontos Centrais do MES}

A redução de custos depende das ações tomadas pró ativamente a partir do MES, ou seja, por meio de pequenas ações tomadas com base em informações. Os dados acumulados de forma passiva e não seguidos por ações, por si só, não são capazes de representar nenhuma melhoria. Com o tempo, o MES pode ser quantificado, contudo deve-se verificar se há a necessidade de uma equipe dedicada para tal, capaz de transpor as atividades diárias. O MES futuramente pode ter opções de acoplamentos diretos com a máquina, sinais elétricos para interromper a programação de máquinas. 
Foi percebido que os estudos literários apontam muitos pontos benéficos do MES, mas na prática é preciso se atentar para a maturidade da empresa, os recursos disponíveis para ações, disposição para mudanças, quantificações de volume e tempo.

Um resultado percebido foi que o MES, além de ser muito útil para aumentar o controle sobre os processos por meio do apontamento em tempo real, pode influenciar também na programação PCP, através de ferramentas de scheduling que permitem os recálculos na programação de jobs, caso haja algum imprevisto no chão-de-fábrica, como quebra de máquinas, ausência de recursos humanos, falta de material.

O MES atuaria, portanto não somente como um elemento passivo para armazenagem de dados, mas também como sugerindo a programação do PCP mais adequada, de acordo com a situação pontual da fábrica.

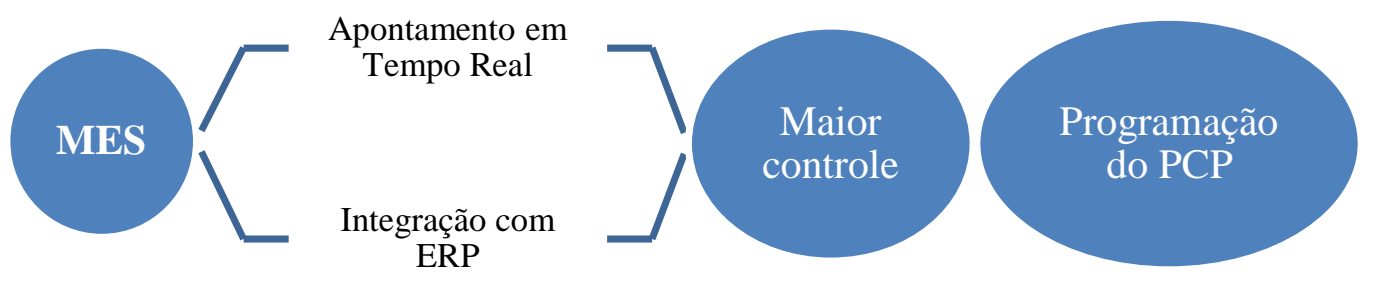

Figura 19 - Pontos do MES

FONTE: Figura elaborada pelo autor da obra.

\section{$\underline{\text { Interseccões dos Casos }}$}

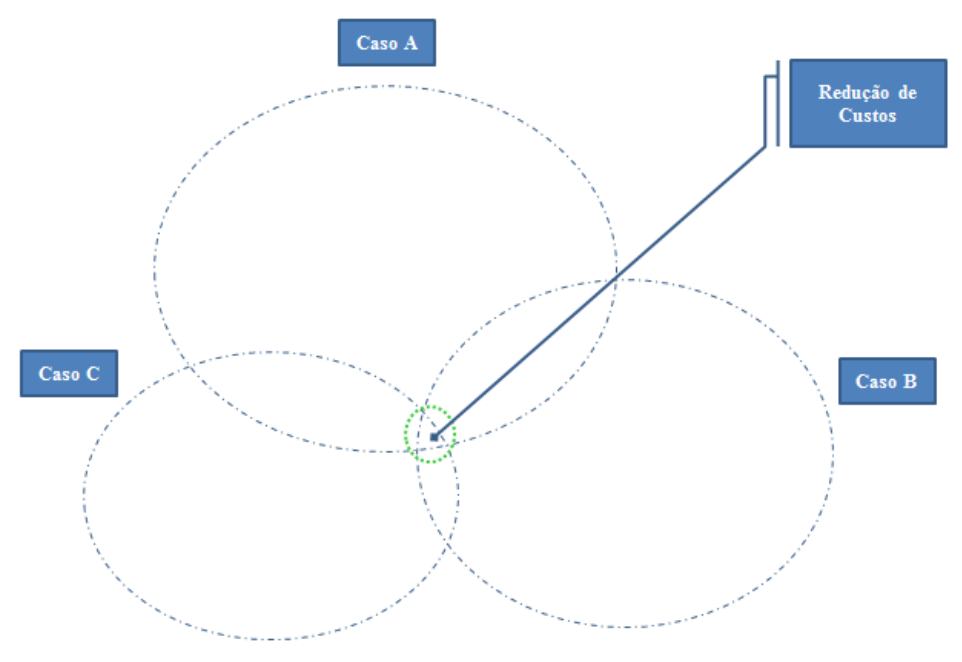

Figura 20 - Intersecção dos casos

FONTE: Figura elaborada pelo autor da obra. 
Nos 03 casos estudados, o MES apresentou como um dos objetivos centrais, a redução dos custos, conforme demonstrado na Figura 20. Apesar do objetivo central se mesclar entre os diversos casos, cada um deles, apresentou também outros assuntos relacionados ao MES que se intercalaram. Outros pontos, porém foram discutidos exclusivamente de acordo com cada análise.

\section{$\underline{\text { Integração com ERP }}$}

Em algumas empresas não se faz presente a integração de ERP com MES, o que dificulta ainda mais a percepção de redução de custos, mas no longo prazo este panorama pode mudar.

Necessidade de a alta diretoria cultivar esta mentalidade, mas depende do chão-defábrica para alimentar também. Disseminar visão financeira casada com a operação e verificar as atividades indiretas.

O MES não retorna ao ERP os tempos reais de execução dos processos, o que também não realizado sequer no ERP. Já o estudo de quantidades é feito no ERP, com base nas listas técnicas e no SOP, ao contrário das análises de capacidades. Atualmente este estudo é desempenhado de forma manual e direcionado apenas aos equipamentos considerados como gargalos.
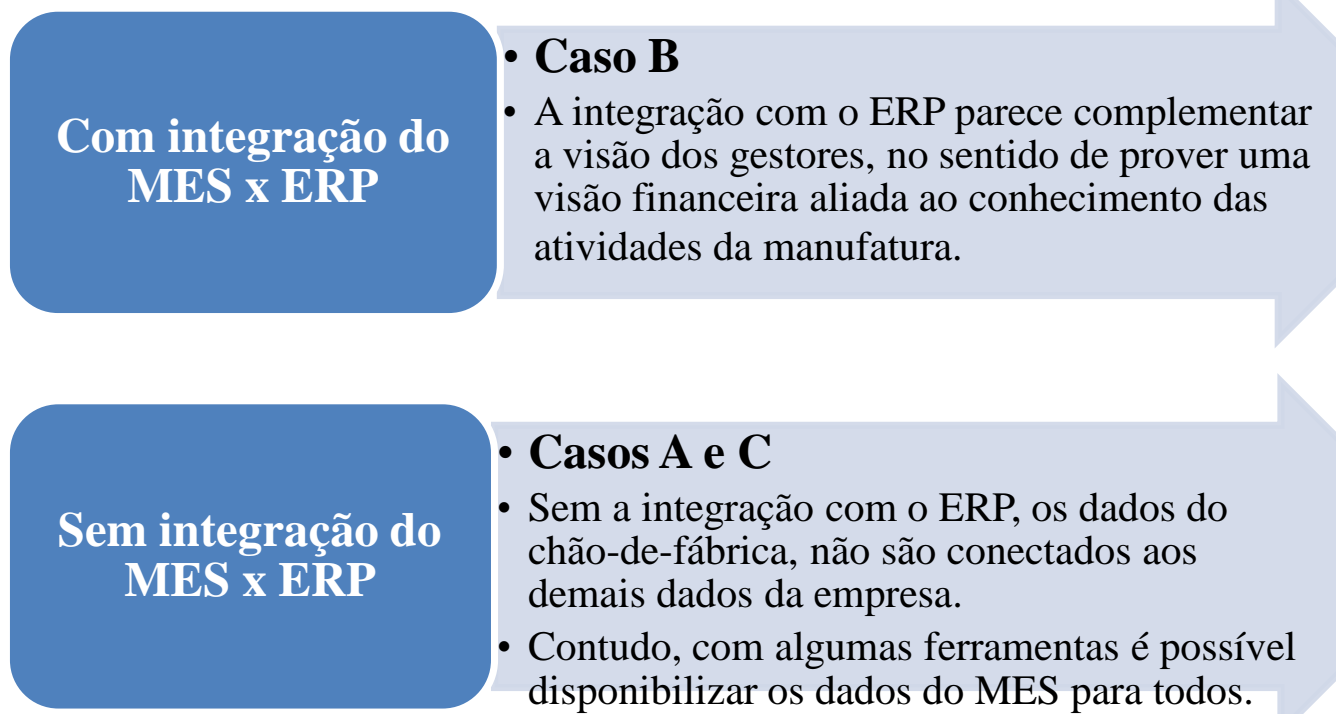

- Casos A e C

- Sem a integração com o ERP, os dados do chão-de-fábrica, não são conectados aos demais dados da empresa.

- Contudo, com algumas ferramentas é possível disponibilizar os dados do MES para todos.

Figura 21 - Integração MES e ERP

FONTE: Figura elaborada pelo autor da obra. 


\section{Maturidade do MES}

Os estudos de casos averiguados nesta pesquisa possuem divergências em termos de estágios na implantação do MES e também em relação ao grau de desenvolvimento de seu uso, maturidade em termos de tempo de implementação. A Figura 22, no entanto, não busca classificar os estágios do MES, inclusive porque não foi identificado nenhum material na literatura que assim o fizesse e também porque o tempo de implementação não é necessariamente proporcional a um grau de maturidade definido do sistema. A figura busca apenas facilitar a percepção do uso do MES em cada caso, após a coleta dos dados.

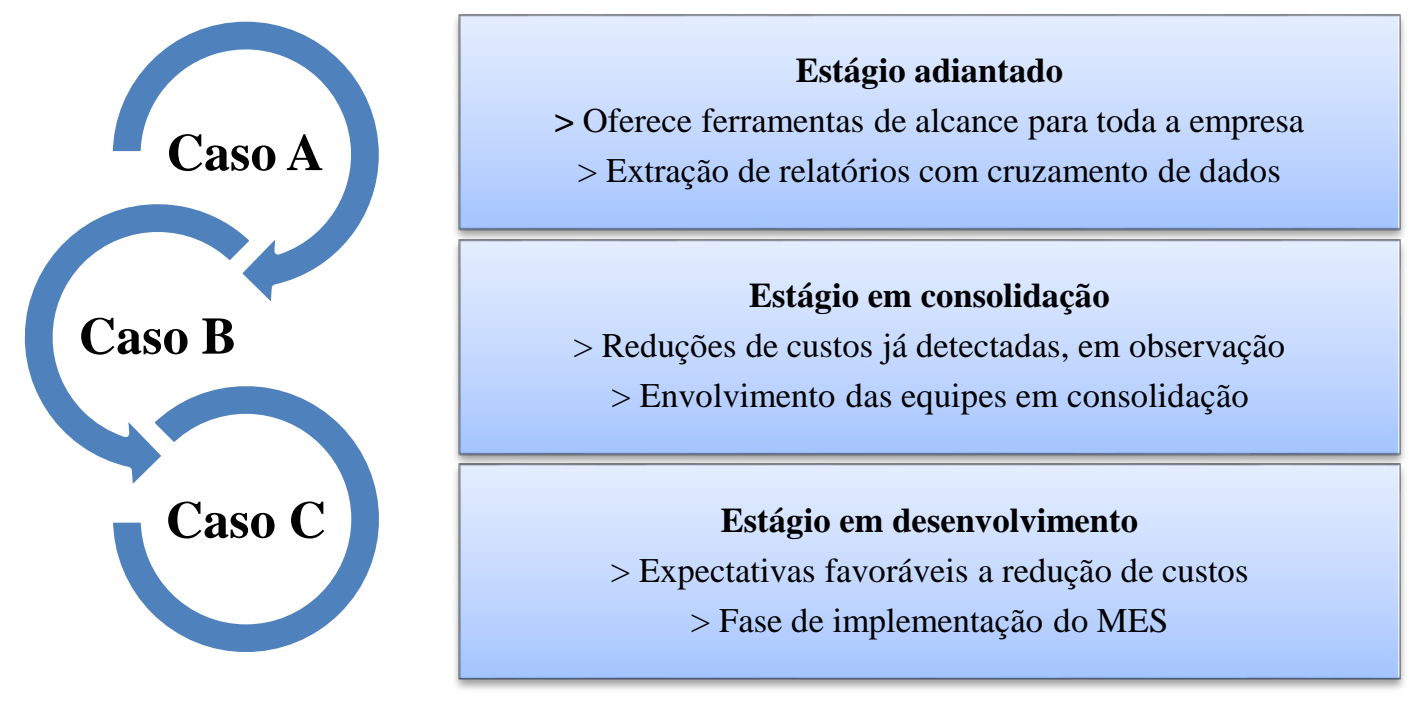

Figura 22 - Estágios do MES

FONTE: Figura elaborada pelo autor da obra.

Outro ponto interessante seria verificar o intevalo de tempo (delta t) necessário para que as empresas alcancem a maturidade desejada para o MES. Nesta análise, não se pode afirmar que exista relação lógica, pois existe empresa com estágio elevado, mas sem integração ao ERP. 


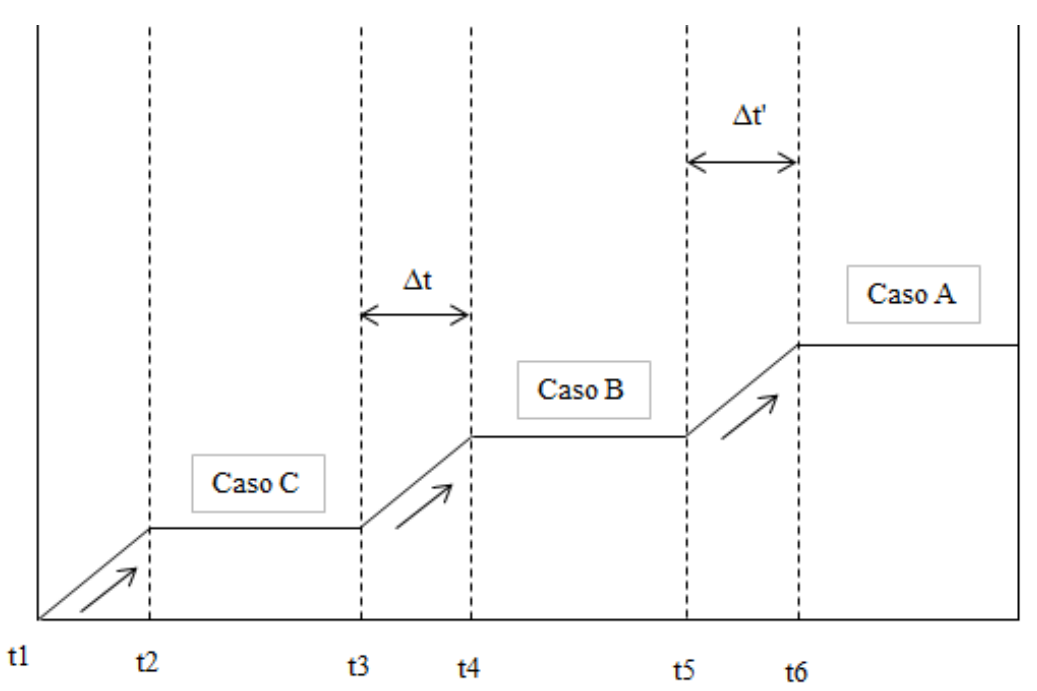

Figura 23 - Níveis de maturidade do projeto

FONTE: Figura elaborada pelo autor da obra.

\section{Porte de Empresa}

No início pretendia-se estudar o fenômeno do MES aplicado em pequenas e médias empresas, mas devido à dificuldade em se encontrar empresas destes portes para a pesquisa, este quesito foi removido. Assim, todos os casos vistos neste projeto correspondem aqueles aplicados em empresas de grande porte.

\section{Tipo de MES}

Em relação ao uso do MES em termos dos tipos de empresas manufatureiras, não foi possível identificar uma diferenciação muito grande. Para atender as especificações de cada tipo de manufatureira, o MES parece atendê-las através de customizações do sistema, mas a essência do sistema é bastante similar em todos os casos.

Este estudo considera o mesmo tipo de MES aplicados para os 03 primeiros casos. Somente no último caso, o MES era de um fornecedor diferente. 


\section{$\underline{\text { Reducão de Custos com MES }}$}

Em nível estratégico e estratégico-operacional, o MES dispõe das ferramentas mencionadas na literatura e na observação empírica deste estudo. Todavia, a Figura 24 procura destacar um ponto relevante percebido que é a tomada de decisão de melhoria de processos a partir dos dados gerados pelo MES, com resultados diretos causados no plano operacional, através da qual poderá resultar em uma melhor gestão dos custos no nível estratégicooperacional que por sua vez poderá resultar em uma eventual redução de custos.

Esta relação, contudo, não se dá necessariamente por fenômenos de causa-efeito, pois a redução de custos pode depender também, em última instância, de elementos além daqueles proporcionados pelo MES. Pode existir uma correlação entre o uso do MES e a melhoria dos resultados operacionais que resultam em uma redução de custos. No entanto, outros fatores externos ao MES, também podem influenciar nesta melhoria e na consequente redução de custos.

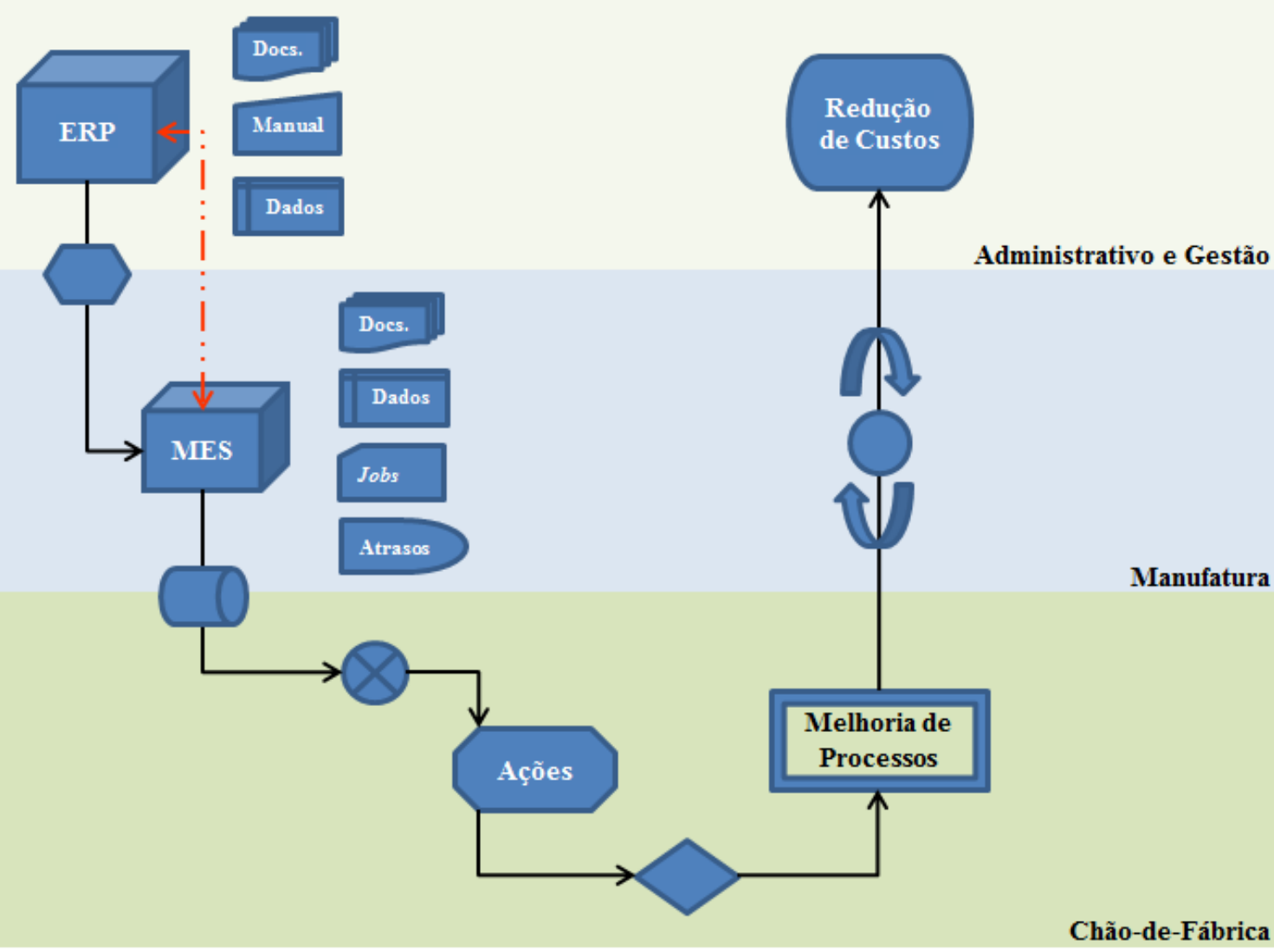

Figura 24 - Resumo do MES

FONTE: Figura elaborada pelo autor da obra. 
O estudo deve ser extenso para identificar todos os departamentos que utilizam informações do MES para alimentar o ERP. Atualmente não existe uma clara visão de como, quando e onde exatamente as informações do MES são utilizadas para a determinação dos custos de produção.

É bastante complexo identificar e relacionar quais informações são inseridas no ERP, por qual departamento e por quais colaboradores, já que as informações são acessíveis a todos da empresa.

No geral, os resultados superaram as expectativas, porém há uma grande dificuldade em equacionar o legado do projeto de forma quantitativa. A visão dos gestores em relação à redução de custos é de que tanto a implantação do MES quanto a sua integração com ERP reduz custos, porém há uma dificuldade em se contabilizar e mensurar esta redução.

A implementação do MES em si, não é a única responsável pelas melhorias e reduções de custos, mas sim, contribui para a geração de informações que por sua vez, oferecem um maior número de opções para que os gestores da companhia possam optar pela adoção de novas técnicas e, mas isto não significa necessariamente que os colaboradores estejam tomando as ações necessárias para de fato reduzirem os custos a partir desta visibilidade.

Tal situação contribui para que a área de engenharia possa atuar de fato em adaptações de processos fabris ou detectar oportunidades de melhoria, que é o objetivo central traçado no início da implementação, liberando relatórios a qualquer instante sobre a situação real da fábrica, com recursos trabalhando e parados, utilização dos recursos, tempos parados, entre outros. 


\section{CONCLUSÕES}

Após a análise dos resultados pode-se observar que o MES tem sido de fato bastante útil para as empresas de manufatura discreta, oferecendo inúmeras opções para os gestores.

Guardadas as devidas ressalvas em termos dos estágios de maturidade do projeto e também das diversas características peculiares de cada caso apresentado neste trabalho, o MES apresenta uma vasta gama de soluções, que desde que aplicadas em conjunto com uma gestão de mudança intensa, podem contribuir muito para a estratégia da manufatura traduzida em operações mais eficazes.

A integração com o ERP pode enriquecer ainda mais a análise dos gestores, por integrar as visões da empresa como um todo, ressaltando inclusive a integração com os aspectos financeiros da empresa.

P1: A integração entre os sistemas ERP e MES em manufaturas discretas pode contribuir para a redução de custos, quando:

\section{a) Existe uma maior confiabilidade no controle de estoque a qual resulta em uma redução de desperdícios com matéria-prima e menor lead-time;}

Os resultados da pesquisa identificam que quando há uma coleta de dados em tempo real do consumo de estoque é apontado de forma mais precisa e menos suscetível a erros de input manual e, além disso, contribui para que os processos sejam mais voltados para a redução do consumo de material.

Um dos exemplos, que promovem ações de redução de desperdícios é a gestão a vista, em que os resultados podem ser acompanhados em monitores em tempo real e encontrados ao longo da fábrica, listando indicadores e gráficos.

Com menor desperdício em termos unitários, há uma redução de custo considerável quando pensado em volumes maiores. 
Uma vez integrado ao ERP, estes custos podem ser atualizados e contabilizados em tempo real, de forma que toda a empresa, e não apenas a manufatura, tenha acesso aos impactos gerados.

Uma vez investido o capital de giro em estoques, que estejam em processo ou acabados, e que não estejam circulando, os custos associados e os juros do tradeoff de investimento podem aumentar consideravelmente.

Se os custos podem ser atualizados e contabilizados em tempo real, então, pode-se ter uma noção melhor de adotar estratégias de reduzir o lead-time e aumentar o giro do estoque.

\section{b) Existe uma alocação adequada de recursos, redução do setup e tempo de parada de máquinas, as quais resultam em um uso mais eficiente da capacidade das máquinas por meio da otimização e flexibilidade da manufatura;}

No aspecto de alocação dos recursos e reajuste em caso de contratempos, pode-se notar que o MES também foi bastante útil para utilizar mais adequadamente a capacidade das máquinas.

Foi identificada também a redução nos setups de máquinas, após a implantação do MES, o que contribuiu bastante para a redução dos tempos e eficiência na produção, com maior uso da capacidade de cada máquina, auxiliando no cálculo da taxa de capacidade/eficiência, evitando a formação de gargalos.

A facilidade para acesso aos relatórios foi reportada em todos os casos. Elementos gráficos nos relatórios de produção e detalhamento via drill-down facilitam a identificação de problemas que antes não eram detectados, gerando possibilidades para reduzir custos.

Contudo, em nenhum caso foi identificada a possibilidade de disparar elementos elétricos automaticamente nas máquinas. Ou seja, as ações dependem de iniciativas da gestão efetivas, para que a resolução de problemas se converta em redução de custos. 
c) Por meio do apontamento real e identificação de problemas decorrentes de programação, existe um melhor planejamento e gerenciamento dos jobs no chãode-fábrica;

Em relação à programação detalhada dos jobs de produção e o gerenciamento de planejamento, o MES apresentou melhorias ao longo dos casos, porém com uma menor intensidade. Pelas características apontadas ao longo da pesquisa, o MES pode vir a contribuir futuramente com o melhor planejamento da produção com maior maturidade neste sentido, por meio de subsídios com uma maturidade um pouco maior e que ofereça visões diferentes.

O MES indica a programação detalhada de atividades de forma consolidada e automática. Mas, a adaptação dos planejamentos elaborados frente a determinadas circunstâncias de eventos incertos e aleatórios ainda ocorre com menor frequência, já que as intervenções dependem da tomada de decisão, após a análise dos dados.

Outro fator que impacta esta análise é o fato de que a integração com o ERP ainda não transporta os dados de jobs concluídos e da performance da operação real.

Em termos de execução e o controle no chão-de-fábrica, com a liberação e planejamento das ordens de produção, distribuição de jobs por máquina, o sequenciamento das operações e o apontamento da produção, traduzindo estes dados em ações detalhadas e executáveis com propósitos de verificação e rastreamento das ordens de produção, o MES tem sido efetivo.

Isto é, o MES possui o banco de dados com informações de controle extraídas do chãode-fábrica, com redução de erros de input, informações inconsistentes e divergentes da realidade. Porém, deve-se converter tais ações em reduções efetivas de custos.

P2: A redução de custos pode ocorrer em decorrência das adaptações e reestruturações de processos frente à adoção do MES

Além das conclusões obtidas com a proposição 02, é possível observar também algumas possibilidades de questionamentos. Seria extremamente relevante pensar também nas causas que são responsáveis pelas mudanças, ou seja, o que gera a mudança de fato? 
Pode-se inferir então que primeiramente houve a percepção de possibilidade de reduzir custos e por isso foi buscada a solução do MES ou instalou o MES e depois a organização percebeu que era possível reduzir custos?

Entende-se que o projeto expõe uma mescla das duas respostas, já que a organização pode ter pensado inicialmente em uma solução, mas ao longo do tempo o sistema pode oferecer mais visibilidade e oportunidades de melhoria. Portanto, há concordância com a proposição e os resultados aferidos no projeto por tais motivos.

Outra conclusão obtida é as organizações não mudam processos apenas com intuito de atender as exigências do MES, ou integrar com o ERP, mas sim para reduzir os custos.

Nem todas as operações são passíveis de medição e automação, principalmente aquelas em que o baixo custo da mão-de-obra, alto valor do equipamento e limitações técnicas não justificam o investimento de tecnologias.

Após a apuração dos dados é possível concluir que todos os entrevistados reconhecem que o MES contribuiu de maneira significativa ou têm expectativas projetadas para a melhoria dos custos, o que corrobora os investimentos procedidos junto aos sistemas.

Diante dos resultados apresentados, o estudo possibilitou analisar o uso do MES e sua integração com o sistema ERP no prisma da redução de custos de empresas manufatureiras do tipo discreta.

Permitiu ainda, observar algumas particularidades da implantação, em relação às dificuldades e pontos a serem aperfeiçoados no MES.

Sobretudo, permitiu resgatar as aplicações benéficas do MES nas empresas de segmentos variados, compreendendo as caracterizações do sistema segundo o tempo de implantação e tipo de segmento.

O projeto evidenciou que a integração com o ERP pode, de certa forma, oferecer os aparatos para melhorar o alcance das reduções de custos, o que culmina em uma relativa concordância com os estudos literários levantados.

Contatou-se que de fato, o uso do MES pode contribuir muito para a redução de custos ou pode apresentar grandes expectativas para. Contudo, foi observado que se faz necessário efetuar as mudanças de processos e operações necessárias para acompanhar este processo evolutivo na redução de custos. 
A mobilização dos recursos em torno do objetivo de implementar o sistema MES por si só pode se apresentar como um fator motivador e que contribui para a mudança necessária de processos.

Além disso, o uso dos recursos oferecidos pelo sistema parece estar bastante relacionado com o grau de maturidade e da fase de sua implementação.

Outro aspecto marcante é que embora a literatura e a prática dos casos do projeto apontem para vários atributos do MES é preciso estudar com maior profundidade outros casos, que consolidem não apenas os atributos aqui mencionados, mas que apresentem situações de sua integração com o ERP.

Portanto, ao finalizar este estudo pode-se observar que os inúmeros pontos levantados pela literatura são encontrados na prática.

Ao término deste estudo, espera-se que novos esclarecimentos possam surgir solidificar o estudo do MES na literatura.

Finalizando, ao longo da pesquisa, o MES se mostrou uma ferramenta de gestão importante, mas que não substitui o papel do gestor e sua influência nas tomadas de decisões da empresa.

Em adição, o estudo compara as diversas tecnologias disponibilizadas no mercado, e compara o controle atual das empresas (por exemplo, via planilhas), isto é, como os custos são controlados atualmente, em contraposição com os métodos desejados para serem utilizados efetivamente (por exemplo, via sistema MES), ou seja, como os custos poderiam ser controlados.

Por outro lado, é preciso enfatizar sobre o papel do coletor de dados, em especial, os indicadores e medidas de desempenho relacionadas ao negócio, e principalmente relacionadas ao controle de custos.

\section{Limitações da Pesquisa}

Ressalta-se que a aplicação da pesquisa foi restrita a apenas poucos casos. Como relatada na metodologia, este projeto possui caráter exploratório e não tem a pretensão de generalizar os fatos aqui discutidos. 
Pelo contrário, busca apenas elucidar sobre algumas questões do tema, verificando possibilidades de estudos futuros que possa solidificar o conhecimento ou contrariar os argumentos apresentados neste trabalho, caracterizando, portanto o caráter exclusivamente exploratório desta pesquisa.

A dificuldade em acionar outras organizações para participar da pesquisa, também pode ser relacionada como uma restrição na pesquisa.

\section{Estudos Futuros}

Outros fatores apontados na literatura e abordados neste estudo devem ser investigados com maior detalhamento.

Como estudo futuro é sugerido investigar a aplicação do MES e os impactos de sua integração com o ERP, em uma gama maior de empresas, em diferentes setores, e de diferentes portes. Com isto, seria possível obter uma amostra maior de dados, viabilizando o cruzamento de dados em indústrias distintas, entre os fatores considerados pelas empresas, estudando o grau de impacto de cada fator, com outros tipos de MES. Este estudo fornece ferramentas para buscar outras estratégias de manufatura, que não as tratadas neste projeto.

Sobretudo, o grau de importância atribuído a cada aspecto do controle de custos para uma determinada indústria.

Por se tratar de um projeto com limitações, são propostos alguns estudos futuros, entre as sugestões, a metodologia poderia ser aplicada em empresas de outros segmentos e portes, com fatores contingenciais diversos, verificando as diferenças encontradas, através de outras proposições e se possível em um nível mais quantitativo, por uma survey.

Nestas propostas futuras, uma das proposições a serem verificadas, é que a integração entre sistemas poderia auxiliar no levantamento da série histórica através de valores mais precisos e alavancar a precisão dos valores.

Em um exemplo para comparação em termos quantitativos, bastaria calcular a quantidade de dias necessários para o apontamento e comparar com os apontamentos atuais. Bastaria também obter o valor de taxa, calculando as variáveis por equipamento, e verificar a economia obtida com 01 equipamento, após a entrada do MES, sem considerar a integração com o ERP. 
Sugere-se que sejam estudados outros fatores como o levantamento dos históricos de entregas atrasadas, quantidades erradas, quebra de máquina, perda de produtividade e ineficiência. Medir o tempo de fluxo entre as ordens, tempo total de processamento, atraso total, estoque em processo, utilização de recursos (tempo ocioso).

Contudo, acredita-se que outros aspectos financeiros poderiam ser confrontados, avaliando os impactos do MES com ênfase sobre o controle dos preços de venda, custos padrão, obtido por meio de série histórica ou média ponderada, custos fixos e variáveis por meio de médias ponderadas, e cálculo de valores presentes a partir de despesas financeiras. 


\section{REFERÊNCIAS}

ADLER, D. J.; HERKAMP, J.; HENRICKS, D.; MOSS, R. Does a manufacturing execution system reduce the cost of production for bulk pharmaceuticals? Eli Lilly and Company, Lilly Corporate Center. 1995.

ARTIBA, A.; ELMAGHRABY, S. E. The planning and scheduling of production systems: methodologies and applications. New York, Springer, $1^{\text {a }}$ ed. 1996.

ATKINSON, A. A.; BANKER, R. D.; KAPLAN, R. S.; YOUNG, S. M. Contabilidade gerencial. $2^{\mathrm{a}}$ ed. São Paulo: Atlas, 2008.

BANERJEE, A.; BOMMU, N.; AGARWAL, P.; JAISANKAR, N. Design of manufacturing execution system for FMCG industries. International Journal of Engineering and Technology. Vol. 5, No 3, 2013.

BANZATO, E. WMS Warehouse management system: sistema de gerenciamento de armazéns. IMAN, São Paulo, 1998.

BAUER, M.; STOETER, S. Enterprise connectivity. In collaborative process automation systems. ISA: 2010.

BERNROIDER, E.W.N. IT governance for enterprise resource planning supported by the DeLone-McLean model of information systems success. Information and Management, Vol. 45, No 5, pp. 257-269, 2008.

BERTI, R. M. Implantação de um MES (sistema de execução de manufatura) em um ambiente de manufatura enxuta. Um estudo de caso em uma linha de montagem de produtos da linha branca. Universidade Federal de Santa Catarina. Programa de Pós-Graduação em Engenharia Mecânica. 2010.

BERTÓ, D.J.; BEULKE, R. Redução de custos. Ed. Saraiva. São Paulo, 2006.

BRUNI, L.A.; FAMÁ, R. Redução de custos e formação de preços. Atlas, $5^{\text {a }}$ ed., 2008.

BUNSE, K.; VODICKA, M.; SCHÖNSLEBEN, P.; BRÜLHART, M.; ERNST, F. O. Integrating energy efficiency performance in production management. Journal of Cleaner Production, Vol. 19, 2011.

CAMPOS, J. G.; MIGUEZ, L. R. Standard process monitoring and traceability programming in collaborative CAD/CAM/CNC manufacturing scenarios. Computers in Industry. Vol. 62, No 3, pp. 311-322, 2011. 
CHOI, B. K.; KIM, B. H. MES (manufacturing execution system) architecture for FMS compatible to ERP (enterprise planning system). International Journal of Computer Integrated Manufacturing. Vol. 15, № 3, pp. 274-284, 2010.

CHOIN, T. M; CHOW, P. S.; LIU, S.C. Implementation of fashion ERP systems in China: case study of a fashion brand. International Journal of Production Economics. Vol. 146, $\mathrm{N}^{\mathrm{o}} 1$, pp. 70-81, 2013.

CHURCHILL, G. A. Jr. A paradigm for developing better measures of marketing constructs. Journal of Marketing Research. Vol. 16, pp. 64-73, 1979.

CLARK, D. ISA S95 presentation. Invensys Operation Management. 2010.

CONFEDERAÇÃO NACIONAL DA INDÚSTRIA. Metodologia dos indicadores industriais. Confederação Nacional da Indústria. Versão 2.2. 2011.

CONFEDERAÇÃO NACIONAL DA INDÚSTRIA. Indicador de custos industriais. Informativo da Confederação Nacional da Indústria. Publicação Trimestral. Gerência Executiva de Pesquisa e Competitividade, Vol. 2, No 1, 2013.

CONFEDERAÇÃO NACIONAL DA INDÚSTRIA. Indicador de custos industriais. Informativo da Confederação Nacional da Indústria. Publicação Trimestral. Gerência Executiva de Política Econômica Vol. 24, Nº 6, 2013.

COOPER, D.R.; SCHINDLER, P. S. Métodos de pesquisa em administração. Porto Alegre: Bookman, 2003.

CORRÊA, H.L.; GIANESI, I.G.N.; CAON, M. Planejamento, programação e controle da produção: MRP II / ERP. Ed. Atlas, São Paulo, 1997.

CORRELL, J. G., EDSON, N. W. Gaining control - capacity management and scheduling. New York, Norris W. Edson, $3^{\mathrm{a}}$ ed. 2007.

COTTYN, J.; LANDEGHEM, H. V.; STOCKMAN, K.; DERAMMELAERE, S. A method to align a manufacturing execution system with lean objectives. International Journal of Production Research. Vol. 49, Nº 14, pp. 4397-4413. 2011.

COTTYN, J.; LANDEGHEM, H. V.; STOCKMAN, K.; DERAMMELAERE, S. The role of a manufacturing execution system during a lean improvement project. MITIP, Norwegian University of Science and Technology. 2011.

DAI, Q.; ZHONG, R.; HUANG, G. C.; QU, T.; ZHANG, T.; LUO, T. Y. Radio frequency identification-enabled real-time manufacturing execution system: a case study in an automotive part manufacturer. International Journal of Computer Integrated Manufacturing. Vol. 25, $\mathrm{N}^{\mathrm{o}}$ 1, pp. 51-65, 2012. 
DAVENPORT, T.H. Putting the enterprise into the enterprise system. Harvard Business Review. Boston, v. 70, № 3, pp. 94-102, 1995.

DBA SOFTWARE. Manufacturing Efficiency Guide, manufacturing fundamentals, continuous improvement and efficiency rating. DBA Software Inc. 2011.

DEUEL, A. C. The benefits of a manufacturing execution system for a plant automation. Manufacturing Execution Systems Services, Honeywell. 1994.

EISENHARDT, K. M. Building theories from case study research. Academy of Management Review. New York, Vol. 14, No 4, pp. 532-550, 1989.

ELIPSE SCADA. Manual de instruções do software. Elipse Software Ltda. Versão 2.29. 2010.

FAST MARKET. New market report: manufacturing execution systems (MES) market (2011-2016). Applications, Global Forecast and Analysis. 2012.

FERNANDES, F. C. F.; GODINHO FILHO, M. Planejamento e controle da produção. São Paulo: Atlas, 2010.

FERRAZZI, A. Manufacturing execution systems: a case study in the aerospace industry. Itália, 2012. Dissertação (Mestrado em Engenharia) - Programa de Gerenciamento em Engenharia da Escola de Engenharia da Università degli Studi di Padova.

FLICK, U. Uma introdução à pesquisa qualitativa. $2^{a}$ ed. Porto Alegre: Bookman, 2004.

FRANÇOISE, O.; PELLERIN, M. B. R. ERP implementation through critical success factors management. Business Process Management Journal. Vol. 15, № 3, pp. 371-394, 2009.

FRASER, J. Beyond plant-to-enterprise: inside your plant and across the supply network. Cambashi white paper. 2011.

GAITHER, N.; FRAZIER, G. Administração da produção e operações. Pioneira Thomson Learning, $8^{\text {a }}$ ed., 1999.

GAMA, E. B. Benefícios obtidos na colaboração entre sistemas MES e sistemas de manufatura digital do PLM - Diagnóstico. São Carlos, 2011. Dissertação (Mestrado em Engenharia da Produção) - Departamento de Engenharia de Produção da Escola de Engenharia da Universidade Federal de São Carlos.

GEORGES, M. R. Modelagem dos processos de negócio e especificação de um sistema de controle da produção na indústria de auto-adesivos. JISTEM Revista de Gestão da Tecnologia e Sistemas de Informação. Journal of Information Systems and Technology Management. Vol. 7, No 3, pp. 639-668, 2010. 
GIACON, E. Implantação de sistemas de programação detalhada da produção: levantamento das práticas de programação da produção na indústria. Escola Politécnica da Universidade de São Paulo. Programa de Pós-Graduação de Mestrado em Engenharia. 2010.

GIACON, E.; MESQUITA, M.A. Levantamento das práticas de programação detalhada da produção: um survey na indústria paulista. Revista Gestão e Produção, Vol. 18, No 3, pp. 487 498, 2011.

GIFFORD, C. When world collide in manufacturing operations. ISA best practice book. 2011.

GIL, A. C. Métodos e técnicas de pesquisa social. $5^{\text {a }}$ ed. São Paulo: Atlas, 2006.

GOLDRATT, E. M.; FOX, R. E. A corrida pela vantagem competitiva. $5^{\text {a }}$ ed. Ed. Educator. São Paulo: 1994.

GRIEVES, M. Product Lifecycle Management - Driving the next generation of lean thinking. New York: McGraw-Hill, 2006.

GUTIERREZ, V. C. P.; JÚNIOR, A. R.; ARIMA, C. H. A importância do ERP no processo de planejamento e controle de custos. $7^{\circ}$ CONTECSI Congresso Internacional de Gestão da Tecnologia e Sistemas de Informação. FEA USP. 2010.

HAIR, J.; BLACK, W. C.; BABIN, B. J.; ANDERSON, R. E. Multivariate Data Analysis. Englewood: Prentice Hall, 2010.

HALGARI, P.; MCHANEY, R.; PEI, Z. J. ERP systems supporting lean manufacturing in SMEs. Enterprise information for systems business integration in SMEs: Technological, organizational, and social dimensions. Hershey, PA: Business Science Reference. 2011.

HAYES, R.; UPTON, D.; PISANO, G.; WHEELWIGHT, S. Em busca da vantagem competitiva. Porto Alegre: Bookman, 2008.

HE, D. An approach for ISA-95 application to industrial systems. Finlândia, 2012. Dissertação (Mestrado em Tecnologia). Tampere University of Technology.

HORNGREN, C.T.; DATAR, S.M.; FOSTER, G. Contabilidade de custos. Prentice Hall, Vols. 1 e $2,11^{\text {a }}$ ed., 2004.

HORNGREN, C.T.; DATAR, S.M.; FOSTER, G. Contabilidade de custos. Prentice Hall, 9a ed., 1997.

HUANG, X.; WANG, Y.; ZHAO, L.; CHAI, T. Contemporary Integrated Manufacturing System Based on ERP, MES and PCS in Ore Dressing. $8^{\text {th }}$ International Conference on Control, Automation, Robotics and Vision. Research Center of Automation. Northeastern University. 2004. 
HWANG, Y, D. The practices of integrating manufacturing execution systems and six sigma methodology. International Journal of Advanced Manufacturing Technology. Vol. 31, pp. 145-154, 2006.

INTERNATIONAL SOCIETY OF AUTOMATION. ANSI/ISA-95.00.01-2000 Enterprisecontrol system integration part 1: models and terminology. Technical Report. Industry, Systems, and Automation Society (ISA), Pittsburgh, USA. 2000.

INVENSYS. Baltika masters brewing automation with Invensys MES software solution. Invensys Operation Management. Invensys success history. 2011.

JAHANYAN, S.; UPADHYAY, P.; DAN, P. K. Factors influencing ERP implementation in Indian manufacturing organizations. A study of micro, small and medium-scale enterprises. International Journal of Engineering and Technology. Vol. 24, № 2, pp. 130-145, 2011.

JÚNIOR, W. A. Tecnologias de Informação para a integração da manufatura, com ênfase à programação da produção. Centro Universitário Araraquara. Programa Nacional de PósDoutorado. Departamento de Engenharia de Produção. 2009.

JUNQUEIRA, G. S. Análise das possibilidades de utilização de sistemas supervisórios no planejamento e controle de produção. São Carlos, 2003. Dissertação (Mestrado em Engenharia da Produção) - Departamento de Engenharia de Produção da Escola de Engenharia da Universidade Federal de São Carlos.

KAPLAN, R. S.; NORTON, D. P. A execução premium: a obtenção de vantagem competitiva através do vínculo da estratégia com as operações do negócio. $2^{\mathrm{a}}$ ed. São Paulo: Atlas, 2009.

KLETTI, J. Manufacturing execution systems (MES). Verlarg Berlin Heidelberg: Springer, 2007.

KOVALESKI, J. L.; MARÇAL, R. F.; SILVA, A. D. Gestão Estratégica de Manutenção no Ambiente de Manufatura Enxuta. XXV Encontro Nacional de Engenharia de Produção. Porto Alegre, 2005.

LAURINDO, F. J. B. Tecnologia da informação, planejamento e gestão de estratégias. Ed. Atlas. São Paulo, 2008.

LAWRENCE, W.B. Contabilidade de custos. São Paulo: Ibrasa, 1977.

LEE, S. M.; HONG, S. G.; KATERATTANAKUL, P.; KIM, N. R. Successful implementations of MES in korean manufacturing SMEs: an empirical study. International Journal of Production Research. Vol. 50, No 7, pp. 1942-1954, 2012.

LEONE, G.S.A. Custos: planejamento, implantação e controle. $2^{a}$ ed. São Paulo: Atlas, 1989. 
LI, F. Study of multi-agent based integratable manufacturing execution system model. College of Mathematics and Computer Science Wuhan Textile University. Vol. 366, pp. 268271, 2012.

LIRA, A. M.; PARISI, C.; PELEIAS, I. R.; PETERS, M. R. S. Uses of ERP systems and their influence on controllership functions in brazilian companies. Journal of Information Systems and Technology Management. Revista de Gestão da Tecnologia e Sistemas de Informação. Vol. 9, No 2, pp. 323-352, 2012.

LIU, X.; WANG, Y.; MENG, Q. Study on the integrated cost management system based upon ERP/MES/PCS in special steel enterprises. International conference on Human System Interaction. pp. 1004-1008. 2008.

MARCONI, M. A.; LAKATOS, E. M. Técnicas de pesquisa. $3^{\text {a }}$ ed. São Paulo: Atlas, 1996.

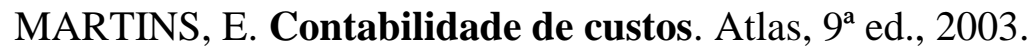

MARTINS, V.; BREMER, C.F. Proposta de uma ferramenta de integração entre sistemas ERPSCADA: caso prático. In: XXII Encontro Nacional de Engenharia de Produção. Curitiba, 2002.

MCKAY, K. N.; BUZACOTT, J. A. The application of computerized production control systems in job shop environments. Computers in industry. Vol. 42, pp. 79-97, 2000.

MENON, A.; VARADARAJAN, P, R. A model of marketing knowledge use within firms. Journal of Marketing. Vol. 56, pp. 53-71, 1992.

MANUFACTURING ENTERPRISE SOLUTIONS ASSOCIATION. The benefits of MES A report from the field. Manufacturing Enterprise Systems Association, Chandler, Arizona. 1997.

MESQUITA, A.M; LUSTOSA, L.; QUELHAS, O.; OLIVEIRA, R. Planejamento e controle da produção. ABEPRO. Ed. Campus. Rio de Janeiro, 2008.

MEYER, H.; FUCHS, F.; THIEL, K. Manufacturing execution systems. Optimal design, planning and deployment. New York: McGrawHill, 2009.

MOMOH, A. R.; SHEBAB, E. Challenges in enterprise resources planning implementation: state-of-the-art. Business Process Management Journal. Vol. 16, № 4, pp. 537-565, 2010.

NYAGA, G. N. Examining supply chain relationships: do buyer and supplier perspective on collaborative relationship differ? Journal of Operations Management. 2010. 
OMAN, S. Application of intermediate document message in the process of enterprise resource planning and manufacturing execution system integration. Problems of Management in the 21st Century. Vol. 2, pp. 141-156, 2011.

OWCZARCZYK, K. Increasing focus on operational excellence drives the European MES market. Frost and Sullivan. 2010.

PADOVEZE, C. L. Contabilidade gerencial. Ed. Atlas. São Paulo, 1998.

PEREZ, J. H., OLIVEIRA, L. M; COSTA, R. G. Gestão estratégica de custos. Ed. Atlas. São Paulo, 1999.

PORTER, M. Vantagem competitiva: criando e sustentando um desempenho superior. Ed. Campus. Rio de Janeiro, 1994.

POWELL, D.; RIEZEBOS, J.; STRANDHAGEN, J. O. Lean production and ERP systems in small- and medium-sized enterprises: ERP support for pull production. International Journal of Production Research. Vol. 51, No 2, pp. 395-409, 2013.

POWELL, D. ERP systems in lean production: new insights from a review of lean and ERP literature. International Journal of Production Research. Vol. 33, No 11/12, pp. 1490-1510, 2012.

QIFENGL, W.; ZHANGJIAN, W. Study on the system architecture and multi-view implementation mode for service-oriented manufacturing execution system. Modern Logistics School of Zhejiang Wanli University. Advanced Materials Research. Vols. 179-180, pp. 586$589,2011$.

REITER, B. S.; KOLDITZ, J.; HILDEBRANDT, T. Engineering autonomously controlled logistic systems. International Journal of Production Research. Vols. 47, No 6, pp. 14491468, 2009.

RICCIO, E. L. Efeitos da tecnologia da informação na contabilidade. Estudo de casos de implementação de sistemas empresariais integrados ERP. São Paulo, 2001. Tese de Livre Docência - Departamento de Contabilidade e Atuária da Universidade de São Paulo.

ROLÓN, M.; MARTÍNEZ, E. Agent-based modeling and simulation of an autonomic manufacturing execution system. Computers and Industrial Engineering. Vol. 63, pp. 53-78, 2012.

ROLÓN, M.; MARTÍNEZ, E. Agent learning in autonomic manufacturing execution systems for enterprise network. Computers and Industrial Engineering. Vol. 63, pp. 901-925, 2012.

SANGSTER, A.; LEECH, S. A.; GRABSKI, S. ERP implementations and their impact upon management accounts. Journal of Information Systems and Technology Management. Vol. 6, No 2, pp. 125-142, 2009. 
SCHMIDT, A.; OTO, B.; ÖSTERLE, H. A functional reference model for manufacturing execution systems in the automotive industry. Association for Information Systems AIS Electronic Library (AISeL). Wirtschafinformatik Proceedings. paper 89, 2011.

SILVA, F. P.; PEREIRA, N. A. Modelagem de processos de negócios na implementação de ERPs nacionais em PMEs. Produção, Vol. 16, № 2, pp. 341-352, 2006.

SLACK, N.; CHAMBERS, S.; JOHNSTON, R. Administração da produção. Atlas, $2^{\mathrm{a}}$ ed., 2002.

SNIDER, B.; SILVEIRA, G. J. C. D.; BALAKRISHNAN, J. ERP implementation at SMEs: analysis of five Canadian cases. International Journal of Operations and Production Management. Vol. 29, $\mathrm{N}^{\mathrm{o}}$ 1, pp. 4-29, 2011.

SOUSA, R.; VOSS, C. Quality management: universal or context dependent? Production and Operations Management, Vol. 10, pp. 383-404, 2001.

SOUZA, G. P.; ASSUMPÇÃO, M. R. P.; SOARES, S. Tecnologia da informação aplicada à logística: estudo de caso em terminal portuário. A globalização e o avanço tecnológico aumentaram a importância da logística empresarial. $7^{\circ}$ CONTECSI Congresso Internacional de Gestão da Tecnologia e Sistemas de Informação. FEA USP. 2010.

STANO, P.; SIMEONOV, S.; CIROVIC, I.; PFAFF, O. Application range of integrating manufacturing execution system functions in enterprises. Annals of DAAAM for 2011 and Proceedings of the 22nd International DAAAM Symposium. Vol. 22, $\mathrm{N}^{\circ}$ 1, 2011.

STRAUSS, A.; CORBIN, J. Pesquisa qualitativa: técnicas e procedimentos para o desenvolvimento de teoria fundamentada. $2^{\mathrm{a}}$ ed. Porto Alegre: Bookman, 2008.

TACHIZAWA, T. Metodologia da pesquisa aplicada à administração. Rio de Janeiro: Pontal, 2002.

TENKORANG, R.A; HELO, P. Enterprise Resource Planning (ERP): a review literature report. Proceedings of the World Congress on Engineering and Computer Science. Vol. 2. 2011.

THEÓPHILO, C. R.; MARTINS, G. A. Metodologia da investigação científica para ciências sociais aplicadas. São Paulo: Atlas, 2007.

TUBINO, D. F. Manual de planejamento e controle da produção. São Paulo: Atlas, 1997.

UGARTE, B. S.; ARTIBA, A.; PELLERIN, R. Manufacturing execution system - a literature review. Production Planning and Control: The Management of Operations, Vol. 20, $\mathrm{N}^{\mathrm{o}} 6$, pp. 525-539, 2009. 
VANDERLEI, M. L. Implantação de controle baseado no sistema de execução de manufatura (MES): análise em empresa de usinagem no setor aeronáutico. Taubaté, 2009. Dissertação (Mestrado em Engenharia Mecânica) - Departamento de Engenharia Mecânica da Universidade de Taubaté.

VOSS, C.; TSIKRIKTSIS, N.; FROHLICH, M. Case research in operations management. International Journal of Operations and Production Management, Vol. 22, $\mathrm{N}^{\mathrm{o}}$ 2, pp.195$219,2002$.

VOSS, C.; KATE, B. Differences in manufacturing strategy decisions between japanese and western manufacturing plants: the role of strategic time orientation. Journal of Operations Management, Vol. 16, pp. 147-158, 1998.

XIA, Y.; LOK, Y.; YANG, S. The ERP implementations of SME in China. Proceedings of the $6^{\text {th }}$ International Conference on Services Systems and Service Management. pp. 135-140, 2009.

YIN, R. K. Estudo de Caso: planejamento e métodos. $3^{\text {a }}$ ed. Porto Alegre: Bookman, 2005.

YIN, R. K. Estudo de Caso: planejamento e métodos. 4ª ed. Porto Alegre: Bookman, 2010.

YIN, Y. H.; XIE, J. Y. Reconfigurable manufacturing execution system for pipe cutting. Enterprise Information Systems. Vol. 5, Nº 3, pp. 287-299, 2011.

YOUNUS, M; HU, L.; YONG, Y.; YUQING, F. Realization of manufacturing execution system for a batched process manufacturing industry. Proceedings of the World Congress on Engineering and Computer Science. Vol. 2. 2009.

ZHAO, X.; HUO, B.; WILLEM, S. W.; HOI, Y. Y. J. The impact of internal integration and relationship commitment on external integration. Journal of Operations Management. Vol. 29, $\mathrm{N}^{\mathrm{o}}$ 1, pp. 17-32, 2011.

WANG, M. L.; QU, T.; ZHONG, R. Y.; DAI, Q. Y.; ZHANG, X. W.; HE, J. B. A radio frequency identification-enabled real-time manufacturing execution system for one-of-a-kind production manufacturing: a case study in mould industry. International Journal of Computer Integrated Manufacturing. Vol. 25, No 1, pp. 20-34, 2012.

WANG, M. L.; QU, T.; ZHONG, R. Y.; DAI, Q. Y.; ZHANG, X. W.; HE, J. B. RFID-enabled real-time manufacturing execution system for discrete manufacturing: software design and implementation. International Conference on Networking, Sensing and Control. 2011.

WEIL, M. MES buyer's guide for managing automation. Managing Automation Media Research Service. Thomas Publishing Company. 2011

WHITLOCK, S. State of the market: manufacturing execution systems (MES). Technology Evaluation Centers. 2012. 


\section{APÊNDICES}

APÊNDICE 1 - CARTA DE APRESENTAÇÃO DA PESQUISA

APÊNDICE 2 - MODELO DE QUESTIONÁRIO SEMI-ESTRUTURADO

APÊNDICE 3 - CRUZAMENTO DE RESULTADOS COM TABELA RESUMO 


\section{APÊNDICE 1 - CARTA DE APRESENTAÇÃO DA PESQUISA}

\subsection{Questionário Semi-Estruturado}

Para a pesquisa de campo foram elaboradas algumas questōes, verificando as principais particularidades oferecidas pela integraçāo entre os sistemas ERP e MES sob uma óptica de reduçāo de custos, revelando algumas diferenças notadas e também as desvantagens ou necessidades que as médias empresas demandam e que nāo sāo atendidas pelas integraçōes.

Este trabalho será analisado sob algumas perspectivas distintas sobre o tema da reduçāo de custos, e dentre as abordagens os principais elementos citados a partir das entrevistas e coletas de dados, além da revisāo bibliográfica e literaturas discorridas. Dentre aqueles elencados, serāo organizados após a aplicaçāo dos testes e análise de resultados.

A finalidade de elencar os principais elementos é verificar sob cada aspecto a preocupaçāo dos gestores e também averiguar se a integraçāo entre o sistema ERP e o MES pode auxiliar em controles presentes e/ou futuros por intermédio de cada indicador.

É fundamental reforçar que o principal objetivo nāo consiste na seleçāo dos elementos a serem pesquisados, mas sim confrontar diferentes opiniōes, revelar tendências e verificar pontos em que as integraçōes possam ser úteis.

\section{APÊNDICE 2 - MODELO DE QUESTIONÁRIO SEMI-ESTRUTURADO}

Para a pesquisa de campo foram elaboradas algumas questões, verificando as principais particularidades oferecidas pela integração entre os sistemas ERP e MES sob uma óptica de redução de custos, revelando algumas diferenças notadas e também as desvantagens ou necessidades que as médias empresas demandam e que não são atendidas pelas integrações.

Este trabalho será analisado sob algumas perspectivas distintas sobre o tema da redução de custos, e dentre as abordagens os principais elementos citados a partir das entrevistas e 
coletas de dados, além da revisão bibliográfica e literaturas discorridas. Dentre aqueles elencados, serão organizados após a aplicação dos testes e análise de resultados.

A finalidade de elencar os principais elementos é verificar sob cada aspecto a preocupação dos gestores e também averiguar se a integração entre o sistema ERP e o MES pode auxiliar em controles presentes e/ou futuros por intermédio de cada indicador.

É fundamental reforçar que o principal objetivo não consiste na seleção dos elementos a serem pesquisados, mas sim confrontar diferentes opiniões, revelar tendências e verificar pontos em que as integrações possam ser úteis.

A primeira etapa do questionário deverá se destinar ao levantamento de dados econômicos e demográficos das indústrias, tal qual o modelo explicitado a seguir:

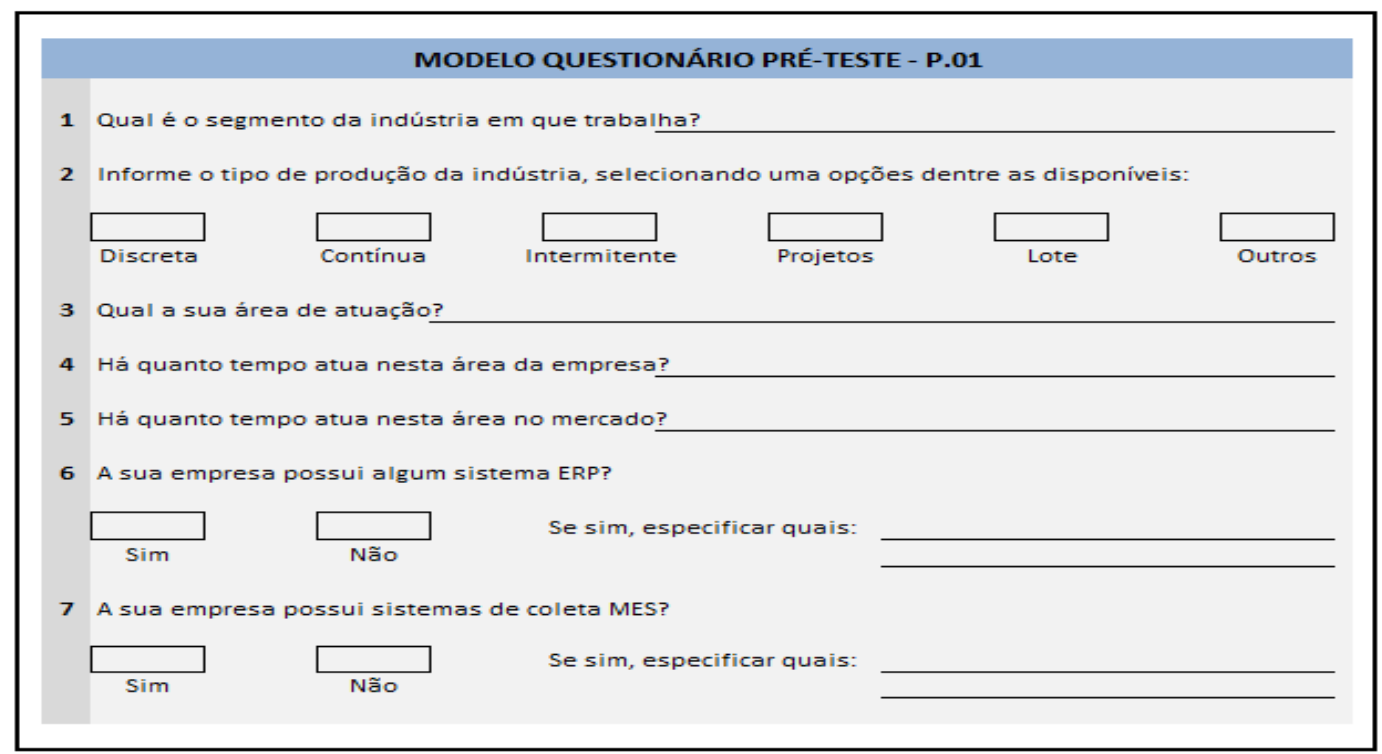




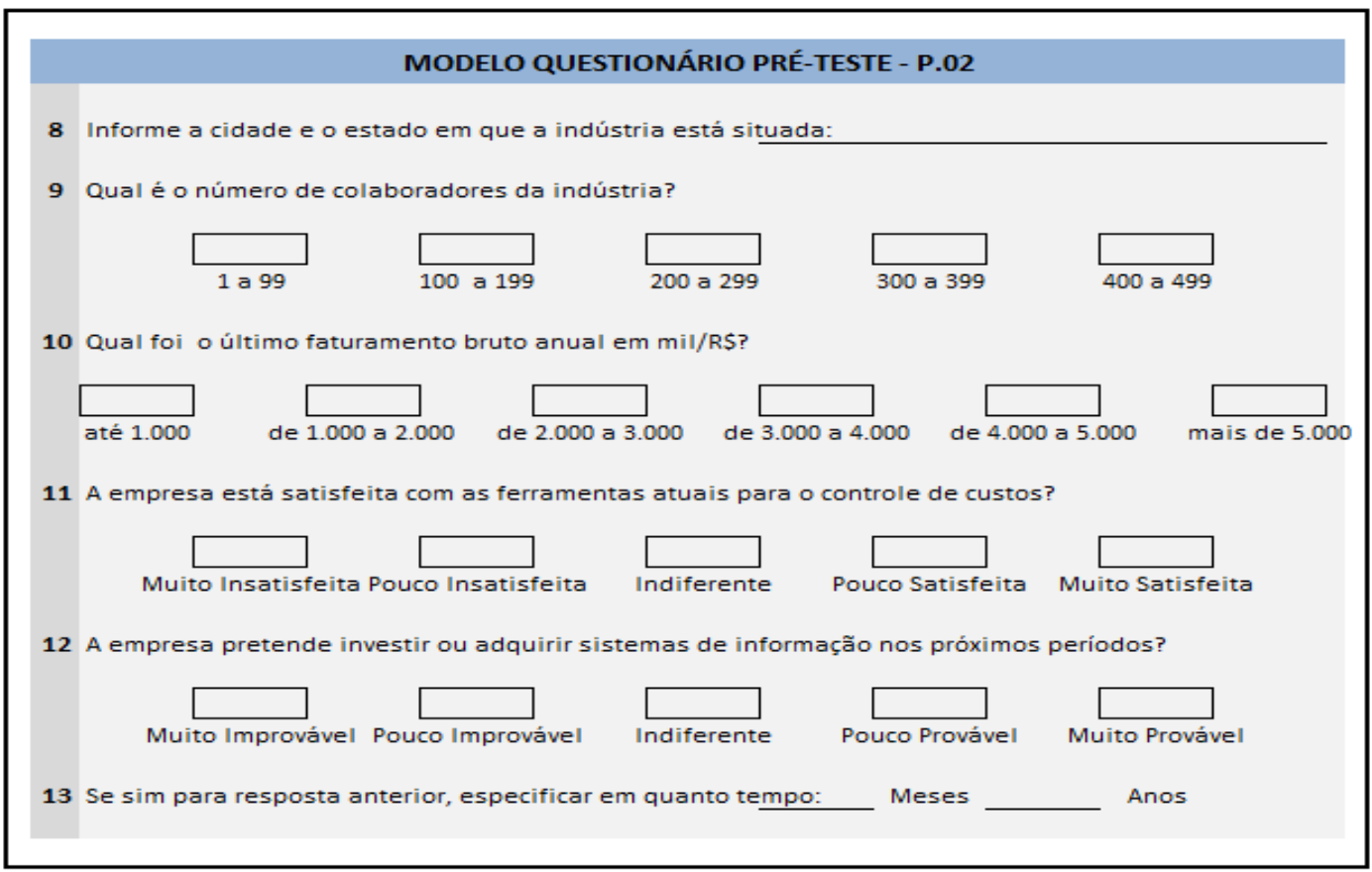

As questões norteadoras da pesquisa serão:

\section{ESTRUTURA DA EMPRESA}

- Quais as linhas de produtos desenvolvidas pela organização?

- Como é a estrutura organizacional da empresa?

\section{IMPLEMENTAÇÃO DO MES}

- Há alguma área específica de TI para tratar de assuntos relacionados a investimentos em tecnologias?

- Quais os fatores utilizados para a implementação de novos sistemas e quem participa da decisão?

- A empresa adota a integração de sistemas de informação na empresa? Como este processo ocorre?

- A empresa adota ou pretende adotar o conceito de integração dos sistemas ERP e MES? 
- Existe uma integração entre os sistemas ERP e MES? Desde quando?

- Em caso afirmativo, de que forma o processo de implementação do sistema MES transcorreu?

- Qual o critério utilizado para a escolha do sistema MES?

- O que foi alterado no processo com a entrada dos sistemas?

- Quais as principais diferenças entre o processo atual e o anterior em relação à coleta de dados de manufatura? Explicite como era o processo anterior de coleta de dados e como ocorre no processo atual.

- Porque houve a decisão na implementação de sistemas? Em que circunstâncias a empresa optou por este investimento?

- De um modo geral, como as informações do chão-de-fábrica são gerenciadas e alimentadas nos sistemas gerenciais?

- Quais os motivos que levaram a empresa adotar novos sistemas de informação? Como ocorreu este processo?

- Descreva como é a estabilidade dos sistemas quando comparada aos controles manuais executados anteriormente.

- A inovação ocorreu principalmente em qual área?

- Qual o nível de envolvimento dos participantes no projeto?

- Ainda considerando a questão, quais foram os principais desafios encontrados ao longo deste processo?

- Explicitar as principais características do sistema MES implantado na organização, elencando os obstáculos de implantação, vantagens e desvantagens obtidas no processo, além dos impactos na organização.

\section{REDUÇÃO DE CUSTOS}

- Considerando a questão anterior, os resultados superaram as expectativas ou renderam abaixo do esperado? Os custos de implementação superaram os resultados gerados?

- Houve economia de custos? Dividir por cada fator da proposição (lead-time, desperdícios, tempo de setup, capacidade) 
- Aponte qual a iniciativa mais impactante para a redução de custos.

- Quais os ganhos obtidos com redução de setup, lead-time e desperdícios?

- Do ponto de vista após a implementação, foram identificadas reduções consideráveis de custo na organização?

- Descreva brevemente as medidas ou métodos adotados para otimizar a redução de custos de produção nos últimos 03 anos.

- Qual é a visão dos gestores em relação a este conceito de integração em relação à redução de custos?

- Elencar os principais fatores de redução de custos e informar o grau de importância e impacto nas operações de cada um destes fatores.

- Informar o nível de detalhamento de cada variável em relação aos procedimentos atuais de redução de custos.

- Informar o nível de detalhamento de cada variável em relação aos possíveis e futuros procedimentos de redução de custos, considerando a integração dos sistemas ERP e MES.

- Quais lacunas poderiam ou não ser preenchidas com a integração de sistemas?

- Quais os fatores que mais contribuíram para a redução de custos?

- Após os investimentos com o MES, a empresa percebeu que poderia investir em outras opções para compensar a alimentação manual de dados? 


\section{APÊNDICE 3 - CRUZAMENTO DE RESULTADOS COM TABELA RESUMO}

\begin{tabular}{|c|c|c|}
\hline PERSPECTIVA & PROPOSIÇÂO & OBJETIVOS \\
\hline \multirow{3}{*}{ MATERIAIS } & \multirow{3}{*}{$\mathbf{P 1}(\mathbf{A})$} & - Controle e rastreamento \\
\hline & & $\begin{array}{l}\text { - Elaboração de listas de materiais } \\
\text { complexas e extensas }\end{array}$ \\
\hline & & ○ Desperdícios e consumo \\
\hline QUALIDADE & $\mathbf{P 1}(\mathbf{A})$ & $\begin{array}{l}\text { ○ Diversidades técnicas e gestão da } \\
\text { qualidade dos produtos } \\
\text { ○ Identificação de problemas }\end{array}$ \\
\hline \multirow{3}{*}{ OPERAÇÕES } & \multirow{3}{*}{$\mathbf{P 1}(\mathbf{B})$} & ○ Múltiplas variações e combinações \\
\hline & & ○ Flexibilidade frente às ocorrências \\
\hline & & ○ Alinhamento de atividades \\
\hline COMPLIANCE & $\mathbf{P 1}(\mathbf{B})$ & $\begin{array}{l}\text { - Estratégias a partir de observações } \\
\text { reais e programas de estimativa de } \\
\text { ocorrências }\end{array}$ \\
\hline
\end{tabular}

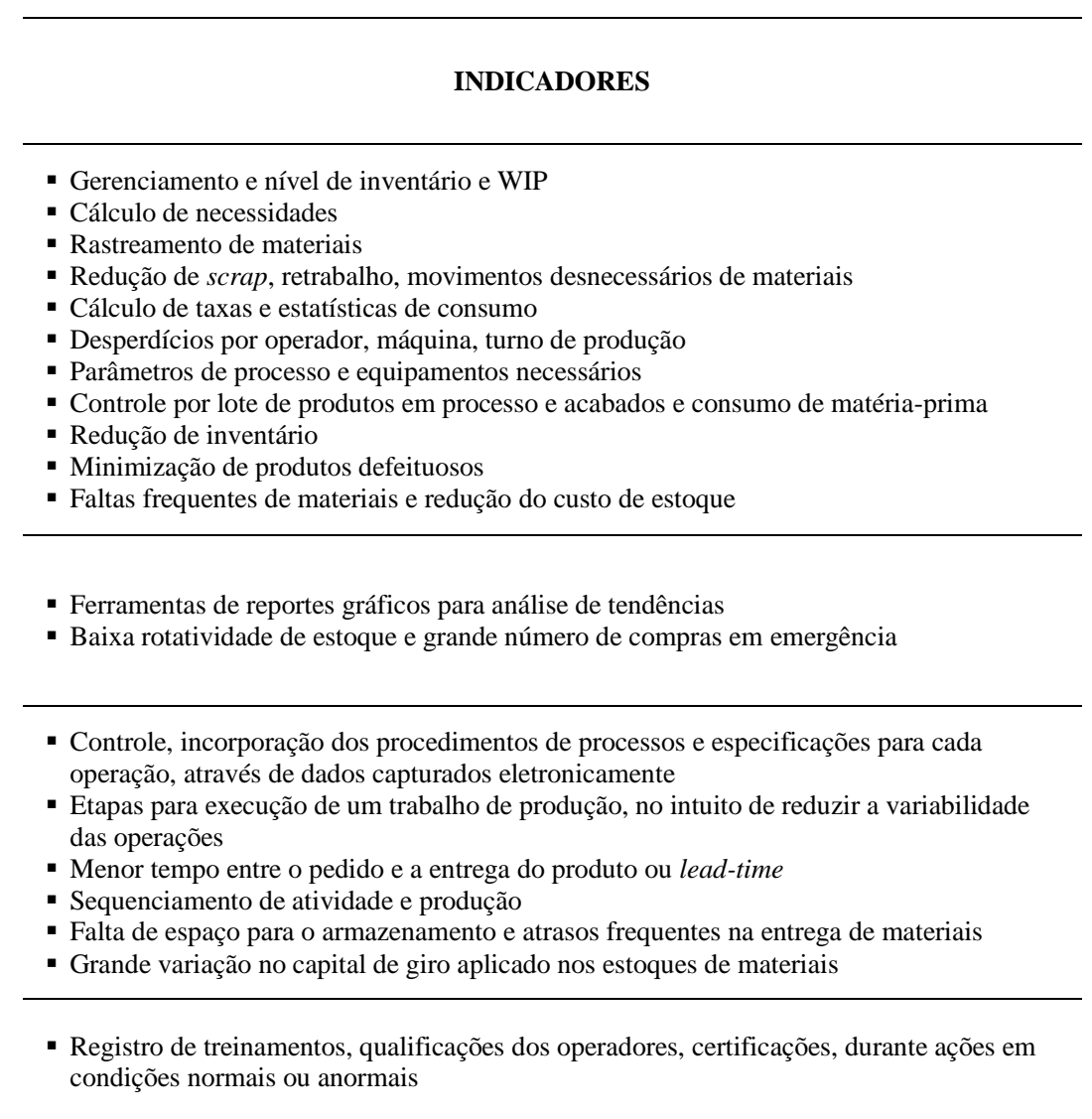


EQUIPAMENTOS

MÃO-DE-OBRA

P1(B)

DISTRIBUIÇÃO

P1(B)

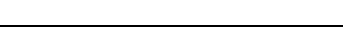

JOBS

$\operatorname{P1}(\mathrm{C})$
- Controlar índice de qualidade e produtividade dos equipamento

○ Tempo investido em ajuste de máquinas e atividades que não geravam valor efetivo

- A alocação de equipamentos com flexibilidade

Capacitação e treinamento

○ Promover a gestão, com

produtividade e taxa de eficiência

○ Distribuição de materiais e

desperdícios/refugos por turno de

produção

○ Indicar a programação detalhada de atividades, por operador e máquina

Responder aos eventos incertos e aleatórios

- Adaptar planejamentos frente às circunstâncias reais da produção

- Evidenciar as causas que geram perdas e os problemas que ocorrem no chão-de-fábrica
- Gerenciar os recursos de equipamentos que possuem alta representatividade dos custos de fabricação do produto

- Maximizar proativamente a Taxa de Utilização efetiva de equipamento, aliada ao agendamento efetivo

- Manutenção e ações preventivas para evitar quebras. Redução de downtimes

- Balancer o uso da máquina e mantença Alocação eficiente de equipanes

- Cálculo taxa da Ca

- Cálculo de Taxa de Capacidade/Eficiência, através de dados e análise de tendências,
reduzindo os tempos ociosos

- Analisar velocidade e consumo de energia. Otimização de produtividade e qualidad

- Gravação de registros de quebras de equipamentos para execução de manutenção

preventiva

- Agendamento e planejamentos efetivos conforme a capacidade de cada máquina, evitando a formação de gargalos

- Minimização de setups e ciclos de trocas e ajustes de máquinas

- Taxa de Uso do equipamento originada pelos turnos de produção

- Controle por estação de trabalho em horas e números por turno

- Melhoria na gestão da mão-de-obra que possui alta representatividade dos custos de fabricação do produto

- Maximizar proativamente a Taxa de Utilização efetiva de mão-de-obra

- Agrupamento de trabalhadores por eficiência, produtividade e alocação

- Atribuição de atividades e operações específicas conforme a habilidade de cada operador

através de documentos, vídeos e checklists

- Necessidade mão-de-obra extra para o próximo turno

- Necessidade dos controles dos custos diretos, como material e mão-de-obra

- O MES propicia ações proativas para a tomada de decisões antes que os erros ocorram

por isso é denominado um early warning system

- Redução ou eliminação do tempo de entrada dos dados e papéis utilizados na operação

- Atualização do Planejamento da Produção, conforme as ações reais no chão-de-fábrica

- Atualização de dados conforme a alteração de turnos, devido às mudanças e imprevistos ocorridos ao longo dos turnos, como a falta de qualidade, restrição de mão-de-obra e

quebra de equipamentos.

Redução do tempo de ciclo, espera e formação de filas

- Rastreamento e posicionamento em tempo real dos trabalhos de produção, fornecendo aos clientes, gerentes e usuários um posicionamento preciso das ordens e o status de cada uma delas

- Sugestão de alternativas para alocação de recursos em caso de contratempos

O registro do histórico estratificado em formato eletrônico permite a comparação de desempenho

- A alocação de novos pedidos pode ser avaliada em curta fração de tempo pelos

planejadores de produção

- Distribuição de jobs por máquina e eliminação dos gargalos 